KURASJE

Krystalgade $16 / 14$ $1172 \mathrm{Kbh} . \mathrm{K}$.

Marxistisk tidsskrift

VÆRDIFORMSANALYSE OG MARXISME

ER DEN VIRKELIGGJORTE SOCIALISME SOCIALISTISK? HABERMAS OG MARXISME 


\section{Abonnement på kurasje nr. 33-36 koster følgende:}

Biblioteker

Støtteabonnementer

Studerende o.lign.

Folk med fast arbejde
$180 \mathrm{kr}$.

$180 \mathrm{kr}$.

$120 \mathrm{kr}$.

$160 \mathrm{kr}$.

Særtilbud: nr. 29-32 incl. samlet for 100,- kr.

Kurasjes gironummer: 7166044

Kurasje

Krystalgade 16

1172 København K ekspeditionstid:

Tirsdag og torsdag.

Telf.: 01-147151

\section{Sats: G.M.T. Tryk: Special-Trykkeriet Viborg a-s}

Tidsskriftet behandler en lang række emner med det formål at bidrage til etableringen af en konkret formidlet kritik af det kapitalistiske system og det borgerlige samfund, samt til diskussionen af overgangsformer til det kommunistiske samfund. Vi opfordrer interesserede til at indsende manuskripter til redaktionen.

\section{Kontaktpersoner:}

Odense, Lars Qvortrup, Skovalle 5, 5250 Odense SV Århus, Hans-Jørgen Thomsen, Heibergsgade 2511, 8000 Århus C. Aalborg, Peter Søndergaard, Faldtvej 14, 9330 Dronninglund Helsinki, Arto Noro, Sociologisk Institut, Helsinki Universitet Jyväskylä: Risto Eräsaari, Samhällspol. Inst. Jyväsky lä Universitet Frankfurt, Jürgen Ritsert, Fachbereich Gesellschaftswissenschaft, J. W. Goethe Universität 


\section{TIDSSKRIFTET KURASJE Nr. 32 \\ April 1983}

\section{Indhold}

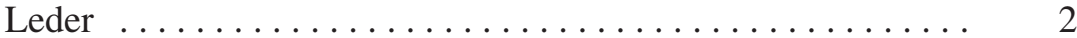

Peter Bundesen

Hvor socialistisk er den virkeliggjorte socialisme? . . . . . . 4

Knud Pedersen og Thomas Stenderup

Forord til værdiformsanalysen $\ldots \ldots \ldots \ldots \ldots \ldots \ldots \ldots . \ldots 21$

Eldred, Hanlon, Kleiber, Roth

Værdiformsanalytisk rekonstruktion af Kapitalen $\ldots \ldots \ldots .25$

Jørgen Sandemose

Vareanalyse, Bemærkninger om en artikel af

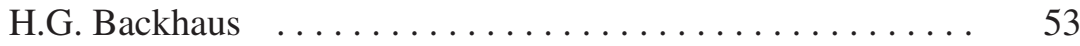

Hans-Jørgen Schanz

Reflektioner omkring Habermas . . . . . . . . . . . . 77

Kommentarer og anmeldelser

Allan Andreassen

Teknologisk udvikling og økonomiseringsformer $\ldots \ldots \ldots 94$

Hans Jørgen Thomsen

Det uendeligt store i det uendeligt små . . . . . . . . . . 103

Redaktionen: Bjarne Andersson, Allan Andreassen, Nils Bredsdorff, Jens Brinch, Peter Bundesen, Leif Hansen, Finn Hansson, Mogens Holm, Peder Lærke Nielsen, Lars Qvortrup, Finn Dam Rasmussen, Peter Søndergaard og Hans-Jørgen Thomsen.

Redaktionens adresse:

Kurasje, Krystalgade 16/14, DK 1172 København K. 


\section{Leder}

I sidste nummer forsøgte vi at komme festivasen i anledning af 100-året for Marx' død i forkøbet. Vi brugte en del plads på at diskutere forholdet mellem Marx og Engels og marxismens udvikling i sikker forvisning om, at den del af historien ikke ville blive viet megen opmærksomhed, når festen begyndte.

I dette nummer, som er færdigredigeret på selve Marx' dødsdag, fremturer vi med at lave disharmonier i festkantaten. Vi opfatter selv tidsskriftet Kurasje som et løbende festskrift for og med »de levende marxismer«, og som udtryk for et program, der mere er lagt an på »Marx til hverdag«, end på jubilæumstalernes halvhjertede lobhudling af en af vor kulturkreds' afdøde åndsfyrster. Denne pludseligt opblussende Marx-interesse, minder alt for meget om »kongens fødselsdag «, hvor alle blir sådan lidt royalistiske for en dag, til at man kan tage den alvorligt.

Vi har derfor heller ikke i dette nummer $\varnothing$ nsket at bringe artikler om Marx gennem 100 år eller lignende. Derimod bringer vi artikler, som er stærkt optaget af, med udgangspunkt i Marx' teoretiske produktion, at udvikle en radikal kritik af vort eget samfund. Når dette er sagt, skal det også straks medgives, at det at tage udgangspunkt hos Marx kan gribes an på mange forskellige måder. Vi er heller ikke sikre på, at der kun bør findes een relevant form for teoretisk rekonstruktion og videreudvikling af det udkast til en kapitalismekritik, der foreligger fra Marx’ hånd.

Kurasje omtales undertiden »universitetsmarxistisk«, »rekonstruktionsmarxistisk « eller »kapitallogisk « tidsskrift. Etikketeringsfors $\emptyset$ gene er oftest negativt ment og i reglen indholdstomme (oftest betyder det blot ikke-partiforberedende eller simpelthen teoretisk), og er derfor vanskelige at forholde sig til. Men i anledning af artiklerne i dette nummer skal vi kort præcisere vores opfattelse af rekonstruktionsbegrebet.

En meget stor del af de artikler vi har bragt og vil bringe har behandlet dele af Marx' økonomikritiske skrifter. Det altafgørende grundtema i disse er undersøgelsen af værdiformen. Artiklerne er for så vidt »rekonstruktionsmarxistiske « som de fors $\emptyset$ ger sig med tolkninger, reformuleringer eller revisioner af den marxske værditeoris fragmenter, og i og med at de forholder sig kritisk til denne teori er de også nødt til at genfremstille denne teori eksplicit. En ikke-rekonstruktionsteoretisk tilgang er kun mulig hvis det ex- eller implicitte udgangspunkt er, at den marxske værditeori foreligger fuldt udarbejdet og fejlfri med indiskutable grænser for sin udsagnskrafts råderum. En sådan tilstand har heller ikke den marxske værditeori nået. 
Spørgsmålet er så om der i rekonstruktionsprogrammet ligger intentioner om at nå »tilbage « til en sådan »ren og sand « marxisme? Teorihistorisk set har der utvivlsomt ligget sådanne intentioner. Efter vores opfattelse er det imidlertid sådan, at selvom det skulle lykkes at nå frem til en indiskutabel udgave af, hvad den afd $\phi$ des værditeori bestod af - om ikke andet så ihverttilfælde af hvad hans værditeorier bestod af - så er hermed blot det fælles grundlag skabt for videre diskussion og uenighed om analysen af den kapitalistiske virkelighed.

$\mathrm{Nu}$ er »rekonstruktionsarbejdet « ikke hele indholdet i »de levende marxismer« og heller ikke dette nummer er udelukkende skruet sammen omkring den problemstilling. En række andre kontrære, kritiske, kapitallogiske, universitetsmarxistiske problemstillinger bliver taget op. Se selv efter.

Hvis du er enig med os i, at det - sammen med de forrige tre numres artikelemner - er vigtige problemer at tage op, så forny dit abonnement for de næste fire numre.

\section{DETTE ER SIDSTE NUMMER}

NY ABONNEMENTSRÆKKE GENTEGN DIT ABONNEMENT BLIV ABONNENT PÅ NR. 33-36 


\section{Hvor socialistisk er den virkeliggjorte socialisme?}

\section{Peter Bundesen}

\section{Indledning}

Hovedsigtet i det følgende er at diskutere nogle teorier om de kommunistpartistyrede landes sociale karakter. Som udgangspunkt argumenteres der for, at enhver forestilling om disse lande som »overgangssamfund « baserer sig på en socialismeforestilling, der dels ikke rækker ud over det borgerlige samfund og dels suggererer en historicistisk forståelse af disse samfund som »overlegne« eller »højere« i forhold til de vestlige kapitalistiske samfund. Det er således påstanden, at overgangsbegrebet blokerer for en forståelse af disse samfunds sociale karakter og reproducerer deres egen legitimationsideologi.

I forlængelse af denne kritik diskuteres det, om disse samfund kan begribes som en form for kapitalisme, eller om de må begribes indenfor en helt anden forståelsesramme. Denne problematik behandles ud fra spørgsmålet om landene skal forstås som henholdsvis »statskapitalistiske« eller »postkapitalistiske«. Her er det påstanden at postkapitalisme-opfattelsens begrundelse for, at man ikke kan betegne disse samfund som kapitalistiske baserer sig på en indsnævret kapitalismeforståelse, som begrænser sig til fordelingsforholdene og derfor ikke medreflekterer produktionsrelationernes kapitalistiske karakter. Derfor reproducerer også postkapitalisme-opfattelsen en forkortet kapitalismekritik.

Hovedsigtet med artiklen er således en gennemgang og kritik af teorier om disse samfundssystemer og kun som grundlag herfor inddrages egentlige analyser af de centrale reproduktionsformer i disse samfund.

\section{Kritik af overgangsforståelsen}

Indtil begyndelsen af tresserne havde den sovjet-docerede marxismeleninisme et tilnærmelsesvist ideologisk monopol på den vesteuropædiske venstrefløj. De fra dengang begyndende opløsningstendenser i dette »monopol « betød også en fornyet diskussion af den grundlæggende samfundskarakter i de lande, der styres gennem kommunistiske partier. Opfattelsen af disse lande som virkeliggjorte socialistiske på vej mod kommunisme blev mere og mere anfægtet. Idag er der kun få - udenfor kp-partierne som ikke vil mene, at den militære magtovertagelse i Polen, forfølgelsen af dissidenter, interventionen i Afghanistan etc. er i modsætning til socialisme. 
Imidlertid blev denne stigende politiske skepsis kun i begrænset omfang ledsaget af en egentlig teoretisk nyvurdering af disse landes sociale udvikling og karakter. Ganske vist er der i stadig stigende grad blevet stillet spørgsmålstegn ved om disse lande nu også kan betegnes som socialistiske, men også de problematiserende holdninger fastholder generelt en marxistisk-leninistisk forståelse af udviklingen, dvs. man også fors $\emptyset$ ger at forstå udviklingen indenfor en liniær evolutionistisk overgangsproblematik mellem kapitalisme og socialisme/kommunisme. ${ }^{1}$

Denne position har både en optimistisk og en pessimistisk variant. I den optimistiske forsikres det, at landene endnu ikke er overgået til socialisme, der findes endnu både kapitalistiske og socialistiske elementer, eller at der er tale om en fase efter kapitalismen, der endnu ikke er socialistisk. ${ }^{2}$ Imidlertid har den pessimistiske variant - som man også kan kalde den trotskistiske - været den mest udbredte på den vesteuropæiske venstrefløj. Indenfor denne påstås det, at der er sket en degenerering af sovjetsamfundet efter Oktoberrevolutionen. Opfattelsen af denne kan være mere eller mindre radikal.

I den forsigtige udgave - den ortodoxe trotskisme - betegnes sovjetunionen som en »degenereret arbejderstat «, hvorimod den radikale udgave går så vidt som til at påstå, at der ligefrem har fundet en rekapitalisering sted. Dette er opfattelsen hos den maoistisk orienterede kritik og den uortodoxe trotskisme. De mest kendte repræsentanter her er henholdsvis »mao-strukturalisten $\ll$ C. Bettelheim og T. Cliff. ${ }^{3}$

1. I den begrænsede danske behandling af disse samfunds karakter er denne overgangsproblematik også fremherskende. Se hertil temanummeret »Marxisme og de socialistiske lande « Historievidenskab nr 171979 og P. Neersø (red.), Sovjetunionens økonomiske system, SØs skriftsserie nr 61981.

Til trods for den altovervejende deskriptive tendens, kan man også spore denne opfattelse $\mathrm{i}$ skrifterne fra Øst- Vest-instituttet på SUC. Her skal der blot refereres til A. Jørgensens artikel »Krisen i Sovjetunionen og Østeuropa«. Han skriver: »Om Sovjetunionen rent faktisk er et socialistisk samfund eller ej, lader sig efter min opfattelse vanskeligt diskutere fra et videnskabeligt standpunkt. Det er snarere et spørgsmål om politisk præference. Det er givet, at privat ejendomsret til produktionsmidlerne er afskaffet, og det er klart, at produktionen søges udviklet efter en plan, som formodes bedst muligt at imødekomme befolkningens behov og udvikle landet på længere sigt. Det er efter min opfattelse også iøjnefaldende, at en række andre fænomener såsom indkomstudjævning, kulturel vækst, stigende social tryghed o.lign. peger i retning af en socialistisk økonomi. « Men da det også er klart, »at den sovjetiske virkelighed i øvrigt har meget lidt med klassiske marxistiske eller andre forestillinger om socialisme at gøre « beslutter han sig alligevel for, at »foretrække at tale om et ikke-kapitalistisk produktionssystem«. (A. Jørgensen, Krisen i Sovjetunionen og Østeuropa, i: J.J. Jensen (red.), Sovjetunionen i Forandring, Esbjerg 1980 ss. 171-172).

2. For en sådan opfattelse se P. Hennickes' artikel i samme (red.) »Probleme des Sozialismus und der Übergangsgesellschaften«, Frankfurt/M 1973.

3. Jeg vil ikke her lave nogen enkeltgennemgang af disse positioner. For korte oversigter kan henvises til Historievidenskab nr $17 \mathrm{og}$ til H. Olsens artikel »Teorier om Sovjetunionens samfundsmæssige karakter«i bogen »Sovjetunionens økonomiske system« (se note 1). 
I det følgende vil jeg kritisere denne fastholdelse i overgangsproblematikken. Jeg vil argumentere for at anvendelsen af overgangsbegrebet er problematisk, og at den sociale struktur i disse lande kun ved anvendelse af et fordelingsteoretisk socialismebegreb meningsfuldt kan siges at være på vej til eller have været socialistiske.

Hvis overgangsbegrebet ikke skal udvandes til det meningsløse, må der kunne redegøres for hvilke samfundsmæssige modsætninger der bestemmer overgangen. Rakovski skriver herom; for at kunne placere et samfund som overgangssamfund må dets grundlæggende institutioner på en gang både forudsætte og udelukke hinanden, således at relationerne mellem samfundets magtcentre ikke er reguleret af mekanismer, der er accepteret som legitime af alle i samfundet, men af mere eller mindre åben klassekrig:

»For at kunne betegne sovjet-samfundene som overgangssamfund er det ikke tilstrækkeligt f.x. at pege på den samtidige tilstedeværelse af central planlægning, og noget der ligner det kapitalistiske marked. Det må også vises, at det første er inkarnationen af producenternes økonomiske magt, medens det sidste inkarnerer virksomhedsledernes magt, og at det legitime samarbejde mellem disse er uopnåeligt på langt sigt. Vi behøver blot at opstille problemet på denne måde for at kunne se, at overgangssamfundsbegrebet ikke kan anvendes på sovjet-samfundene.« (M. Rakovski, Marxism and the analysis of soviet societies, i Capital and Class nr 11977 s. 85.)

Det skal endvidere søges påvist, at overgangsforståelsen betjener sig af et fordelingsteoretisk socialismebegreb, der ikke adskiller sig principielt fra det socialismebegreb, der allerede er kendt fra de teoretiske positioner i den socialdemokratiske arbejderbevægelse og fra marxismen-leninismen selv. Hermed stiller »kritikken« sig grundlæggende på samme teoretiske position som de kritiserede og overser hermed, at en proletarisk social revolution er lige så påkrævet i øst som $\mathrm{i}$ vest.

I den fordelingsteoretiske socialismeforståelse opfattes klasseforholdene som blotte fordelingsforhold, hvorfor ejendom vs ikkeejendom til produktionsmidlerne bliver det afgørende kriterium for klassebestemmelsen. Derfor opfattes det afgørende kendetegn på ophævelse af kapitalismen ikke som ophævelse af kapital-lønarbejderforholdet - og hermed det fremmedbestemte lønarbejde -; men som afskaffelse af privatkapitalisternes ejendomsret over produktionsmidlerne, og indførelse af fordelingsformer, der ikke er bestemt af privatkapitalisternes »blinde « profitjagt, men af politiske beslutninger. I dette perspektiv drejer det sig således ikke om at afskaffe det fremmedbestemte lønarbejde, men om at ændre lønarbej- 
dernes levevilkår. Her overskrider socialismeforståelsen således ikke det borgerlige samfunds horisont.

Da det har været denne socialismeforståelse, der har været altdominerende indenfor såvel II som III Internationale og op til vore dages socialdemokratiske krav om ØD-socialisme, er kritikken af socialismeforståelsen i overgangssamfundsbegrebet samtidig også en kritik af den kapitalistiske arbejderbevægelses socialismeperspektiv.

Opfattelsen af de kp-styrede lande som overgangssamfund baserer sig på en opfattelse af Oktoberrevolutionen som en socialistisk revolution, eller i det mindste som et preludium til samme. Vi kan derfor nærme os en kritik af det fordelingsteoretiske socialismebegreb ved at se på bolsjevikkernes praksis og teoretiske overvejelser omkring Oktoberrevolutionen. Hensigten med denne gennemgang er at eftervise, at den »socialisme«, som de forestillede sig, ikke var en afskaffelse af lønarbejdet, men at deres forståelse lå indenfor det fordelingsteoretiske perspektiv. Det er denne amputerede socialismeforståelse, der også findes i vore dages opfattelse af samfundene som overgangssamfund, hvorfor enhver kritik, der baserer sig på en sådan forståelse, tiltrods for et ofte kritisk udgangspunkt, kun kan reproducere disse samfunds egne legitimeringsformer.

Bortset fra bøndernes allerede tidligere påbegyndte opdeling af storjordbesiddelserne i privatlodder - hvorved der etableredes en fremtidig trussel mod bolsjevikkernes magt - betød Oktoberrevolutionen ikke producenternes tilegnelse af produktionsmidlerne; men dens hovedresultat var derimod bolsjevikkernes - i rådenes navn - erobring af den politiske magt fra den provisoriske regering. Denne magterobring blev så anvendt til omfattende nationaliseringer af produktionsmidlerne. ${ }^{4} \mathrm{R}$. Rotermundt opsummerer resultatet i følgende paradox:

4. Imidlertid ville det være ganske uhistorisk at bebrejde bolsjevikkerne, at de ikke satte kapitalforholdets ophævelse på programmet, for som Rotermundt anfører: »Under de givne historisk-samfundsmæssige forudsætninger drejede det sig ikke desto mindre om det mest udviklede stade, som massebevidstheden overhovedet kunne antage. Den subjektive udvikling af et perspektiv for den kapitalistiske produktionsmådes ophævelse i socialisme forudsætter en udfoldet kapitalisme som grundlag, og ikke - som i Rusland - den isolerede gennemsættelse af lønforholdet i fabriksbyerne. Hvor kapitalforholdet ikke har gennemsat sig totalsamfundsmæssigt kan det heller ikke omstyrtes samfundsmæssigt. Man kan kun bekæmpe det objektivt i delområder og/eller bekæmpe det som Fabrikkens problem (i stedet for som fabrikssystemets problem). Hvor den samfundsmæssige udvikling har skabt denne slags forudsætninger, hvor lønarbejdekapitalforholdet ikke har udfoldet sig til det samfundsmæssigt bestemmende klasseforhold, hvorved der ikke er sket en samfundsmæssig integration af alle producenter, der kan ikke i det borgerlige samfund fremtræde de bevidsthedsudviklinger som er forudsætning for at den socialistiske bevægelse kan tænkes (altså erkendelsen af den menneskelige historie som menneskelig praksis, begribelsen af individet som samfundsmæssigt bestemt osv.); Der mangler proletariatet også grundlaget for at artikulere kravet om bevidst udformning af de samfundsmæssige forhold.«(R. Rotermundt, Oktoberrevolution und Sozialismus, i: Prokla nr 27, 1977 ss. 94-95.) 
»Det var den russiske revolutions paradox, at dér hvor produktionen virkelig blev overtaget af producenterne skete det på privat grundlag (...), men hvor privatejendommen blev ophævet skete den virkelige tilegnelse af produktionsprocessen ikke gennem producenterne, men gennem staten, $-\ll$ (R. Rotermundt op. cit. 101.)

I fortsættelse af nationaliseringerne gennemførtes en større eller mindre udskiftning af markedsprisreguleringerne med statslige plan- og reguleringsmekanismer for produktionsfordeling og forbrug. Oktoberrevolutionen resulterede således ikke $i$ en ophævelse af producenternes underlæggelse i produktionsprocessen, men kun i en erstatning af kapitalens værdiøgningstvang med partistatens plan- og reguleringsmekanismer og overførsel fra privat ejendom til statsejendom.

Er forklaringen på dette begrænsede opgør med de kapitalistiske produktionsforhold, at bolsjevikkerne blev begrænset i deres sociale revolution eller svarer resultaterne også til deres socialismeforestillinger? Hvis vi henholder os til Lenins skriverier må det siges, at det sidste nærmest er det rigtige svar.

Lenin kritiserede primært kapitalismen for dens fordelingsforhold. ${ }^{5}$ Han opfattede kapitalismens grundlæggende modsætning som bestemt af forholdet mellem produktionens tiltagende samfundsmæssige karakter og den private tilegnelse af den. Denne modsætning løses kun ved, at der etableres tilsvarende samfundsmæssige tilegnelsesrelationer, og statsovertagelse opfattedes som en form for dette.

Indenfor en sådan forståelse angår kapitalismekritikken primært dennes muligheder for regulering af arbejdsfordelingen og af dennes produkter; men den kritiserer ikke kapitalismens adskillelse af produktion og behovsrealisering, en adskillelse der er formidlet gennem lønarbejdet. Hermed reduceres socialismeperspektivet til forbedring af lønarbejdernes arbejds- og levevilkår gennem ophævelse af privatejendommen til produktionsmidlerne og erstatning af den »anarkistiske« markedsregulering med en »bevidst « planmæssig regulering. Derimod har en kritik af lønarbejdet som udtryk for tvangen over producenterne i produktionen ingen plads i teorien.

Da Lenin forstod den historiske udvikling af produktivkræfternes samfundsmæssighed som lovmæssigt bestemt, forblev hans kapitalismekritik - foruden kritikken af dens uretfærdige fordeling - primært bun-

5. Dette afsnit støtter sig primært til U. Heidt og E. Mangeng, Parteivergesellschaftung, i: P.W. Schulze, Übergangsgesellschaft: Herrschaftsform und Praxis am Beispiel der Sowjetunion, Frankfurt/M 1974 og B. Rabel, W. Spon og U. Wolter, Halbheiten in der Überwindung des Leninismus, i: Prokla nr 11/12 1974. 
det til, at den som privat tilegnelsesform hæmmer produktivkræfternes udvikling. Socialismen skal så at sige ikke frigøre producenterne fra fremmedherredømmet, men sætte produktivkræfterne fri for begrænsede tilegnelsesformer.

Det fordelingsteoretiske socialismeperspektiv viser sig også i Lenins statsopfattelse. Han opfattede staten som dels et repressionsinstrument for det herskende borgerskab og dels som et $\varnothing$ konomisk administrativt samfundsmæssigt reguleringsinstrument. Det var revolutionens opgave at sønderslå det borgerlige herredømme over staten, hvorimod man også skal anvende dens $\varnothing$ konomisk-administrative potenser i den fremtidige samfundsregulering. Dog skal man i en overgangsperiode også anvende staten til undertrykkelse af borgerskabet. Det langtsigtede perspektiv var således den herredømmefri stat, men indtil da må den fungere som magtinstrument for den nye herskende klasse. Denne statsforståelse forklarer bolsjevikkernes prioritering af den politiske magtovertagelse. Det drejede sig om at erobre statsmagten, for hermed at forvandle den fra at være et herredømmeinstrument for borgerskabet til at blive et herredømmeinstrument imod dette.

For Lenin var det revolutionære subjekt ikke lønarbejderklassen, men det revolutionære avantgardeparti. Han havde overtaget Kautsky's forestilling om at lønarbejderne bevidsthedsmæssigt og organisatorisk umiddelbart begrænser sig til »trade-unionistiske « forestillinger og krav, hvorfor de ikke spontant vil angribe borgerskabets herredømme. Denne angivelige modsætning mellem grænserne for den faktiske bevidsthed i klassen og dens historiske mission søgte Lenin at løse med sit avantgardebegreb. Pga. sin organisatoriske og bevidsthedsmæssige begrænsethed kan klassens spontane kampe ikke overvinde kapitalismen. Avantgarden kan imidlertid pga. sin teoretiske skoling erkende de samfundsmæssige lovmæssigheder og de muligheder som klassens kampe har for at overvinde kapitalismen. Derfor er den i stand til at føre det socialistiske perspektiv ind i de tradeunionistiske massers ellers begrænsede kampe.

Opsummerende kan det fastslås, at spørgsmålet om overgang til kommunisme stillede sig således for Lenin: Pga. kapitalismens begrænsede tilegnelsesformer bliver det for produktivkræfternes fortsatte samfundsmæssige udfoldelse nødvendigt med tilsvarende samfundsmæssige tilegnelsesformer. Dette nødvendiggør imidlertid en politisk revolution, der ophæver privatkapitalisternes privatejendomsret og herredømme. Men da lønarbejderne umiddelbart er bundet ind i trade-unionistiske forestillinger og organisationsformer, må dette politiske magtspørgsmål rejses igennem og under ledelse af et avangardeparti. 
Denne skitsering af bolsjevikkernes teori og praksis omkring Oktoberrevolutionen skulle have vist, at udviklingen i Sovjetunionen og i de østeuropæiske lande, hvortil den sovjetiske samfundsmodel blev »eksporteret« ved afslutningen af Den anden Verdenskrig, må forstås som en politisk magtovertagelse uden ophævelse af de grundlæggende samfundsmæssige reproduktionsbetingelser: adskillelsen mellem produktion og behov, og at den udvikling må forstås som værende i overensstemmelse med bolsjevikkernes forestillinger om hvad socialisme og kommunisme er. Ganske vist opfattede og opfatter de socialismen som en overgang til en magtfri kommunisme. Men da denne overgang kun kan ske som »frihed gennem tvang «, må man stadig mere end 65 år efter Oktoberrevolutionen indrømme, at man stadig er under overgang til kommunisme.

\section{De nye fordelingsformer}

I det forgående har jeg vist, at bolsjevikkernes teoretiske kritik og praktiske »overvindelse « af kapitalismen ikke indeholdt en afskaffelse af det fremmedbestemte lønarbejde, men kun ændring af tilegnelsesog fordelingsformer gennem afskaffelsen af den private ejendomsret til produktionsmidlerne og fors $\emptyset \mathrm{g}$ på at erstatte varemarkedets regulering med statslig planregulering. Da avantgardepartiet har opnået magten over statsapparatet bliver det nye i tilegnelses- fordelingsforholdene dettes magt over planreguleringen af arbejds- og konsumfordeling. Der er således tale om nye reguleringsformer af relationerne mellem produktionsprocesserne og mellem disse og de individuelle konsumtionsprocesser. For at kunne diskutere hvorledes de kpstyrede samfund skal sættes på begreb, vil jeg i det følgende kort analysere grundtrækkene i de nye fordelings- og reguleringsformer. Hvor disse relationer under privatkapitalismen primært er reguleret gennem vareudvekslingen på markedet - af værdiloven, søges de nu reguleret i overensstemmelse med partistatens planmål. Da der fortsat er tale om en adskillelse mellem produktion og behov, er der ikke tale om en ophævelse af kapitalismens adskillelse af disse, men om en ny regulering af denne adskillelse, hvori behovene søges underlagt planmålene.

Denne nye form for regulering af adskillelsen mellem produktion og behov betyder også en ændring i forhold til privatkapitalismens akkumulationsbetingelser. Medens det her er enkeltkapitalisternes profitjag, der driver akkumulationen frem, så findes der ikke efter ændringen en tilsvarende entydig dynamiseringsfaktor. Som det fremgik af det forangående afsnit, var det centralt i bolsjevikkernes kritik af kapitalismen, at den hæmmer produktivkræfternes udfoldelse. I overensstemmelse hermed sigtede 
politikken efter magtovertagelsen i Sovjetunionen på en hurtig produktivkraftsudvikling. Denne politik kan næppe betegnes som entydig succesfuld, også selvom man fra partistatens side har søgt denne udvikling gennemført gennem både belønnings- og straffeforanstaltninger, hvis yderpunkt er arbejdslejrene. ${ }^{6}$ Afgørende for de $\varnothing$ konomiske ændringer er derfor partistatens planmål og dennes mulighed for at gennemsætte disse. Dette adskiller partistatsbureaukratiet fra driftsherrerne under privatkapitalismen. Medens sidstnævntes funktioner udtrykker gennemsættelsen af øgningstvangen, så er partistatsbureaukratiet selv med til at sætte disse betingelser.

Selvom reguleringen principielt sker ved at enkeltvirksomhederne og konsumenterne handler i overensstemmelse med de centrale planmål, så er der i realiteten ikke tale om et sådant klart hierarki. Hvad angår enkeltvirksomhederne, så besidder de informationer, der er nødvendige for den centrale planmyndighed. Det er derfor ikke blot planordrer, der strømmer igennem de økonomiske ledelsesfunktioner, men også klager over problemer ved udførelsen og krav om kompensationer. Systemet indeholder derfor en kombination af direktiver og forhandling. (M. Rakovski, op. cit. s. 89)

Det er derfor relevant at unders $\emptyset$ ge, hvilke modsætninger, der kan opstå mellem den centrale planmyndighed, enkeltvirksomheder og forbrugernes behov. Modsætningerne mellem de centrale planmyndigheder og enkeltvirksomhederne opstår i og med, at der ikke er et sammenfald mellem de centrale planmål for produktionen og dennes fordeling og virksomhedernes interesser, som individuelle virksomheder. Denne modsætning betyder at enkeltvirksomhederne opfylder planmålene på en for dem gunstig, men for helheden uhensigtsmæssig måde. Eksempler på disse modsætninger er legio, f.x. tilbøjeligheden til at producere store og ubrugelige redskaber i stedet for mindre og brugbare, fordi man lettest opfylder planmålene på den første måde. Påpegningen af disse modsætninger er helt centralt for H. Ticktins undersøgelser af forholdene i Sovjetunionen. Han mener, at det mest karakteristiske for denne samfundstype er en stadig voksende spildproduktion. Ticktin mener, at den centrale planlægning reelt er ude af stand til at styre enkeltvirksomhederne, idet disse kan omgå de centrale anvisninger til egen fordel. Denne mangel på kontrol fra de centrale planmyndigheder betyder også, at de ikke er i stand til at allokere de

6. Når vi ser bort fra udelukkelse fra arbejde som politisk disciplineringsmiddel gælder der en »ret til arbejde«. I forhold til privatkapitalismen betyder dette, at partistaten har afskrevet sig et væsentligt $\emptyset$ konomisk disciplineringsmiddel: reservearmeens tryk på de beskæftigede. Dette er en betydelig

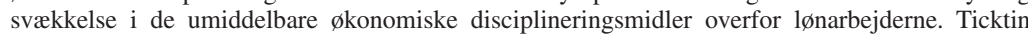
betegner dette som arbejdernes negative kontrol over merproduktet. Se diskussionen mellem Brus og Ticktin, Is Market Socialism Possible or Necessary?, i: Critique nr 141981. 
nødvendige ressourcer, hvorfor enkeltvirksomhederne selv må skaffe sig disse gennem direkte forbindelser til andre enkeltvirksomheder. Resultatet af dette er ifølge Ticktin en totalsamfundsmæssig mangel på regulering. (Se H.H. Ticktin m.fl. Planlose Wirtschaft, Hamburg 1981) ${ }^{7}$

Rakovski anfører, at det er en af partiets - som en organisering på tværs af magthierarkiet - centrale opgaver at modvirke den trussel om systemdesintegration, der ligger i modsætningerne mellem centrale interesser og interesserne hos enkeltvirksomhedslederne. (M. Rakovski, op. cit. 92)

For så vidt hele samfundet ikke fungerer som en arbejdslejr med et striks rationeringssystem, har samfundsindividerne selv valgmuligheder mellem de tilbudte jobs og de mulige konsummidler. Økonomien udtrykker således en dobbelthed med produktion efter administrativt fastsatte principper og atomiserede lønarbejdereksistenser. Disse er dels underordnet produktionen gennem omfang af og fordelingsforhold for konsummidler og dels ved efterspørgslen efter forskellige former for arbejdskraft. Denne indordning af de individuelle behov under partistatens planregulering betyder, at der er tale om et »diktatur over behovene«, som man siger indenfor Budapest-skolen. (Se G. Markus, Planning the Crisis: Remarks on the economic system of Soviet-type societies, i: Praxis International vol 1 no 3 1981.) Dette diktatur er dog ikke absolut politisk bestemt, idet det skal underordnes hensynet til den samfundsmæssige reproduktion. Endvidere varierer dets karakter med omfanget af den »anden økonomi « (produktion og forbrug, der ikke umiddelbart registreres i plansystemet), ændringer i reguleringsformerne for forbruget og i formerne for arbejdskraftsanvendelse og afhændelse af denne. ${ }^{8}$

Efter at partistaten fra slutningen af tresserne ændrede planmålene, således at vægten på massekonsum forøgedes, er der sket en opblødning af dette diktatur, men der er fortsat tale om et sådant, idet det kun er for så

7. Denne bog er et oversat udvalg af artikler fra tidsskriftet Critique, der redigeres af Ticktin.

Selvom man nok kan være noget skeptisk overfor Ticktins mere radikale slutninger, så står der dog det tilbage, at adskillelsen og interesseforskellene mellem centralmyndighederne og enkeltvirksomhederne betyder en begrænsning i centralmyndighedernes kontrol over produktion og fordeling. Det er i relation hertil en pointe hos Ticktin, at en evt. forøget markedsregulering ikke nødvendigvis betyder en større frihed for lønarbejderne, men derimod kan give centralmyndighederne nye og mere effektive kontrolmidler i udøvelsen af deres herredømme. (Se Brus/Ticktin, op. cit. ss. 13-16.)

8. Markus skelner mellem tre typer $\emptyset$ konomi, der gør sig gældende. Den første $\emptyset$ konomi er den officielle plan- eller komandoøkonomi. Den anden økonomi er den private, der mere eller mindre fungerer efter et markeds- og profitprincip. Denne består af privatvirksomheder og kooperativer. De arbejdere, der beskæftiges her, har ofte et andet officielt arbejde og så dette som »måneskinsarbejde «. Den tredie $\emptyset$ konomi er baseret på personnelle, informelle st $\varnothing$ tterelationer. Denne $\emptyset$ konomi er især gældende for forholdet mellem enkeltvirksomheder i den første $\varnothing$ konomi, hvor man gennem sådanne relationer kan imødegå forsyningsvanskeligheder i det centrale system. (G. Markus, op. cit. ss. 253-256) 
vidt partistaten anerkender eller accepterer behovene, at de får mulighed for at blive realiseret.

Imidlertid eksisterer modsætningen mellem enkeltindivid og partistat også i en bredere forstand end i reguleringen af forbruget. Den individuelle lønarbejdereksistens producerer fordringer om personlige, politiske og sociale rettigheder, der står i modsætning til partiets fordring på det samfundsmæssige magtmonopol og individernes underordning under dette.

Jeg har i det forgående skitseret to væsentlige konfliktdimensioner, der opstår i denne samfundstype. Det drejer sig dels om modsætninger mellem de centrale planmyndigheder og enkeltvirksomhedslederne og dels om modsætninger mellem planmyndighederne og enkeltindividerne. Det er ikke afgørende for disse relationers grundlæggende karakter, om de er reguleret monetært eller gennem forskrifter. En overgang til en monetær regulering ændrer ikke nødvendigvis ved de tilgrundliggende magtforhold, men udgør blot en anden - og måske mere effektiv - måde at gennemsætte disse på. ${ }^{9}$

\section{Statskapitalisme eller postkapitalisme?}

I det forgående har jeg kritiseret opfattelsen af de kp-styrede samfund som overgangssamfund; men hvorledes skal man så bestemme denne samfundstype, er der tale om en særlig kapitalistisk form, statskapitalisme ${ }^{10}$ eller er der tale om en samfundstype, der hverken er kapitalistisk, socialistisk eller en overgangsform dem imellem? I det følgende vil jeg se nærmere på en sådan opfattelse, der betegner dem som postkapitalistiske. ${ }^{11}$ I forlængelse af denne diskussion vil jeg se på hvilke forskelle i kritikken som de to forskellige begreber giver anledning til.

9. Jvnf. note 7 .

10. Som det fremgår af W. Olles artikel, Zur Theorie des Statskapitalismus, (i: Prokla nr 11/12 1974) er statskapitalismebegrebet blevet anvendt i mange forskellige betydninger. Det skal derfor præciseres, at betegnelsen i det følgende kun refererer til den venstre- eller rådskommunistiske kritik af de kp-styrede samfund. Denne kritik udvikledes allerede i tilknytning til bolsjevikkernes magtovertagelse i Rusland. Hovedpointerne i denne kritik er dels at Oktober-revolutionen ikke var en proletarisk revolution, men blot var bolsjevikkernes magterobring, og dels at dette ikke kan opfattes som et »forrædderi«, men må ses som udtryk for bolsjevikkernes fordelingsteoretiske socialismeperspektiv, et perspektiv som de delte med socialdemokraterne i Anden Internationele. Da P. Matticks arbejder udgør den teoretisk mest gennemarbejdede position indenfor denne opfattelse, vil jeg i det følgende referere til hans arbejder.

11. Der tænkes her primært på vesttyskerne R. Damus, R. Rotermundt, U. Schmiederer, H. BeckerPanitz, U. Heidt og E. Mangeng, som alle bruger betegnelsen »postkapitalisme«. Selvom Ticktin ikke selv anvender netop dette udtryk, så er hans argumentationer så parallelle med de nævnte vesttyskes at jeg vil behandle ham på linie med disse.

Den nyere østeuropæiske kritik indskriver sig heller ikke i overgangssamfundsforståelsen, hvorfor den havde været relevant at inddrage her. Jeg har refereret til ungarerne Rakovski og Markus. Imidlertid vil jeg ikke her nærmere diskutere deres opfattelse af disse samfundssystemers grundlæggende sociale karakter. 
Rotermundt, Schmiederer og Becker-Panitz mener ikke at man kan betegne disse lande som kapitalistiske. Begrundelsen herfor er, at der kun kan være tale om kapitalisme,

»hvor alt samfundsmæssigt arbejde udføres som privatarbejde, hvorved alle den samfundsmæssige produktions resultater antager varekarakter.« (Rotermundt m.fl., Die Sovjetunion und Europa, Frankfurt 1979 s. 21)

Dette betyder, at også arbejdskraften må have varekarekter. Den kapitalistiske produktionsmådes klasseforhold er derfor betinget af, at varerelationen er blevet den almene samfundsmæssige relation. Til kapitalisme-bestemmelsen hører derfor dels, at »værdiloven« skaber den samfundsmæssige syntese »bag om ryggen« på producenterne og dels at disses forhold til totalarbejdet fremtræder som et samfundsmæssigt forhold mellem ting. (Rotermundt m.fl. 1979 op. cit. s. 21)

Ud fra disse »krav« er det åbenbart, at man ikke kan tale om kapitalisme i den her undersøgte samfundstype. Det er dog problematisk ved Rotermundt m.fl.'s afgrænsning, at de binder bestemmelsen alene til fordelingsformerne - syntesen gennem vareforholdene - og ikke til de forhold, der fremkalder denne form for syntesedannelse, nemlig adskillelsen mellem produktion og behov.

Denne problematik vil jeg fastholde ved nærmere at unders $\varnothing$ ge postkapitalisme-positionens centrale kritik af statskapitalismeopfattelse. For det første fremføres det, at statskapitalismeopfattelsen suggererer en falsk forståelse af, at der fortsat er tale om en markedsreguleret kapitalistisk produktion med varer, priser og profit. For det andet anføres det, at der slet ikke er tale om lønarbejde i denne samfundstype.

Hvad angår den første indvending påpeger kritikkerne, at pengepriser spiller en helt anden rolle i disse samfund end i de privatkapitalistiske, idet de ikke anvendes som medium til regulering af forholdet mellem produktion og behov, men primært anvendes til formidling af at tvangskonsum, altså kun tjener til realisering af den af planmålene bestemte produktion. (Rotermundt m.fl. 1979, op. cit. s. 35) Priserne angiver derfor ikke det abstrakte arbejdes værdistørrelse, men er derimod i væsentlighed bestemt af partistatens reguleringsinteresser. ${ }^{12}$

Endvidere påpeges det at profitten ikke har samme betydning for akkumulationen som under privatkapitalismen, da produktionen af profit her ikke er den grundlæggende rationalitet, for enkeltvirksomhederne.

12. Dette må betyde at pengepriserne ikke fungerer som værdimål, men kun som prismålestok. Ticktin udtrykker dette noget kryptisk ved at anføre, at pengene kun fungerer som generel ækvivalent og ikke som almen. (H. Ticktin m.fl., op. cit. s. 51). 
Det afgørende orienteringspunkt for disse er derimod »afsætningsvolumer«. (H. Ticktin m.fl. op. cit. s. 38).

Hvad angår den rådskommunistiske statskapitalismeopfattelse så synes disse indvendinger at være fejladresseret. ${ }^{13}$ Man må derfor sige, at lige så rigtige som disse påpegninger er, lige så irrelevante er de, som kritik af Matticks statskapitalismeopfattelse, idet Mattick deler opfattelsen af, at tilstedeværelsen af priser her ikke betyder at systemet er reguleret gennem vareværdiernes konkurrence på markedet:

»Statskapitalisme er stadig et »merværdi« producerende system, men det er ikke længere et system, der finder sin »regulering « gennem markedskonkurrence og krise. Merproduktet kræver ikke længere markedskonkurrence for at kunne realiseres som profit; dets specifikke materielle karakter og dets distribution afledes af bevidste beslutninger fra de statslige planlægningsorganers side. At disse beslutninger også er bestemt af international økonomisk og politisk konkurrence og af akkumulationens krav ændrer ikke det faktum, at manglen på et indre kapitalmarked kræver et centralt bestemt, direkte beslutningssystem med henblik på allokeringen af det samlede samfundsmæssige arbejde og fordelingen af det totale samfundsmæssige produkt.«(P. Mattick, 1973, s. 248-249) $)^{14}$

Der er således taget hensyn til de nye fordelingsformer i Mattick's statskapitalistismeforståelse, hvilket også fremgår af, at han bestemmer det statskapitalistiske system ved at »regeringsbeslutninger og økonomisk planlægning bestemmer produktion, distribution og udvikling.« (P. Mattick, 1973, op.cit. s. 239)

Den anden indvending mod statskapitalismeopfattelsen var, at det under denne samfundstype slet ikke er meningsfuldt at tale om lønarbejde, og hermed om et lønarbejder-kapital forhold. I det følgende vil jeg referere R. Damus' argumentation desangående fra hendes Kursbuch-artikel »Ist die Arbeit im Sozialismus Lohnarbeit? « fra 1974. $)^{15}$

Indledningsvis kritiserer Damus statskapitalismeopfattelsen for at begå den fejl, at reducere lønarbejdet til et aktivitetskendetegn eller en betalingsmåde, og derfor ikke begribe lønarbejdet som et socialt for-

13. For en sådan fejladressering se H. Ticktin m.fl., op. cit. s. 25 note 1.

14. Det skal dog anføres, at Mattick selv er med til at bringe usikkerhed om sin argumentation ved at skrive, at det er et »merværdi«producerende system. Gåseøjnene signalerer nok en ny anvendelse af værdibestemmelsen, men de forklarer den ikke.

15. Benægtelsen af, at man skulle kunne tale om lønarbejde, findes tilsvarende hos R. Rotermundt, m.fl. op cit. s. 28, men ikke hos Heidt/Mangeng. Ticktin imødegår ikke direkte opfattelsen af, at der eksisterer fremmedbestemt lønarbejde. Derimod argumenterer han for at arbejdskraften ikke er en vare, da der ikke eksisterer noget egentligt arbejdskraftsmarked. (H. Ticktin m.fl., op. cit. ss 48-52). 
hold. (R. Damus, op. cit. s. 92) Herudfra mener hun ikke, at man kan tale om lønarbejde under »postkapitalismen«. Som afsætning for denne argumentation fastslås det, at det som karakteriserer kapitalismen er, at det samfundsmæssigt enhedsstiftende princip ligger i bytteforholdene. Disse udgør de indirekte forbindende bånd mellem de formelt frie og lige samfundsmedlemmer. Denne form for samfundsmæssig syntese betyder, at herredømmeforholdene bliver middelbare - formidlet over byttet.

Et ikke-kapitalistisk samfund er derfor rent logisk bestemt ved negationen af syntese-dannelsen gennem bytteforholdene. Denne negation kan enten føre til ophævelse af herredømmet, og hermed til etableringen af »konkrete samfundsmæssiggørelsesformer« eller til nye herredømmeformer, hvis karakter er umiddelbar. Hvad angår de her behandlede postkapitalistiske samfund, så skabes den samfundsmæssige syntese gennem planøkonomi. Selvom der ikke her er tale om »konkret samfundsmæssiggørelse«, så er der dog tale om en negering af byttet som samfundsmæssig syntese, og hermed af kapitalismen. Damus' begrundelse for, at der ikke er tale om »konkret samfundsmæssiggørelse«, men om nye umiddelbare herredømmeformer baseres på, at der i planlægningen anvendes traditionelle ansporingsmidler. Derfor er planen udtryk og middel for nye herredømmeforhold. (R. Damus, op. cit. s. 93-99)

Da plansystemets herredømme er direkte, begrænser det sig ikke kun til bytteprocessen. Hermed ophæves den tilsyneladende, faktiske delvise selvstændighed mellem de samfundsmæssige delområder. De bliver alle underlagt den politiske vilje.

»Heraf følger, at der ikke kan tales om lønarbejde; det kan der ikke fordi den direkte samfundsmæssige syntese, der gennemsættes via den umiddelbare og dermed politiske herredømmeudøvelse, ikke blot udøves overfor arbejdskraften hos varebesiddere, der som sådan er formelt frie og lige individer. Herredømmet reproduceres nemlig ikke over den middelbare sociale tvang til at sælge arbejdskraften, men langt snarere rådes der direkte over individerne i deres helhed.« (R. Damus, 1974, op. cit. s. 100-101, cit fra s. 101.)

Damus' afvisning, af at tale om lønarbejde under postkapitalismen, er altså baseret på, at hun begrænser det kapitalismekarakteristiske til samfundssyntesen gennem varebyttet, hvorved kapitalherredømmet reduceres til det indirekte herredømme i vareudvekslingen. Dette betyder at hun i sin kapitalismebestemmelse slet ikke indreflekterer denne synteses forudsætning: produktionens adskillelse fra producenternes behov. 
Derfor reflekteres driftsherrens herredømme i produktionen ikke som kapitalismebestemt. Ej heller får hun begrebet det politiske herredømme over privatejerne som moment i det kapitalistiske herredømme. For så vidt disse direkte herredømmeformer også begribes som momenter i det kapitalistiske herredømme, kan de privatkapitalistiske samfund ikke adskilles fra de »postkapitalistiske « ud fra Damus' distinktion indirekte/ direkte herredømme. ${ }^{16}$

Selvom partistaten griber ind overfor alle lønarbejdernes livsforhold, ændrer det ikke ved det grundlæggende forhold, at den enkelte arbejder, for at kunne reproducere sig, må stille sin arbejdskraft til rådighed, hvor den kan afsættes. Hermed argumenterer jeg kun for, at lønarbejderbegrebet ikke er meningsløst; men jeg har ikke dermed påstået, at lønarbejdet - som under privatkapitalismen - har varekarakter under disse forhold. Prisen på arbejdskraft bliver ikke primært fastsat gennem markedskonkurrencen, der er omfattende restriktioner i arbejdsmarkedsmobiliteten og endelig spiller selve den udbetalte løn kun en begrænset rolle for den enkeltes reproduktionsmuligheder. (Se H.H. Ticktin m.fl. op. cit. s. 48-52)

Det er altså kun ved at reducere det kapitalismebestemmende til udvekslingsforholdene, at Damus kan benægte tilstedeværelsen af lønarbejde under »postkapitalismen«. Betegnelsen »postkapitalisme « bliver problematisk, hvis man derimod fastholder et kapitalismebegreb, der tager udgangspunkt i produktionsbetingelserne. Det er det Mattick gør, når han påpeger, at kapitalisten grundlæggende ikke er karakteriseret ved ejendom til produktionsmidlerne, men som »konsument af arbejdskraft«. (P. Mattick, op. cit. s. 258) Da dette fremmedbestemte herredømme over producenten ikke ændres med de nye samfundsmæssiggørelsesformer, mener Mattick, at det er berettiget at fastholde kapitalismebestemmelsen også for disse samfund. Det nye er blot, at produktionsmidlerne i stedet for at være ejet af privatkapitalister nu er ejet og kontrolleret af staten, privatkapitalisterne er blevet erstattet af en statskapitalist. Denne ændring er selvfølgelig ubehagelig for de tidligere privatkapitalister, men for lønarbejderne gælder det stadig, at de er underlagt et fremmedherred $\emptyset$ mme i produktionsprocessen. (P. Mattick, Marxism - Yesterday, Today, and Tomorrow, i: Root and Branch nr 10, 1981 s. 24.)

16. Det utilstrækkelige i denne distinktion fremgår også af hendes forsøg på at eksemplificere, at der i postkapitalismen til forskel fra i kapitalismen eksisterer et direkte herredømme over arbejderen, idet der her bliver disponeret over ham fra vugge til grav. De eksempler som hun fremfører på dette - f.x. reguleringen af individernes udfoldelsesmuligheder gennem tilladelse til bestemte uddannelsesmuligheder - adskiller sig ikke principielt fra den statslige regulering der er kendt i de kapitalistiske velfærdslande. (R. Damus, op. cit. s. 101). 
Lønarbejdet eksisterer fortsat som formidler af adskillelsen mellem produktion og behov, og hermed gælder også lønarbejdets »dobbelte frihed «: udelukkelsen fra direkte rådighed over produktionsmidlerne og retten til selv at afhænde sin arbejdskraft. Kun for så vidt der er tale om en helt igennem tvangsmæssig allokering af arbejdskraften, kan man tale om lønarbejdets afskaffelse.

Man kan indvende imod Matticks kapitalismebestemmelse, at den modsat binder kapitalismebestemmelsen ensidigt til produktionsrelationerne - kapitalisten som konsument af arbejdskraft. Dette åbner for en udvidelse af kapitalismebestemmelsen til at gælde for alle tvangsregulerede samfund med adskillelse mellem produktion og behov, og hermed negligere værdireguleringens centrale betydning for kapitalismebestemmelsen. Uden at ville konkludere definitivt, mener jeg, at der her ligger en væsentlig problematisering af statskapitalismeforståelsen. Dog skal det i relation hertil påpeges, at der også i de privatkapitalistiske lande sker en betydelig politisk bestemt fordeling af produktionen, så også her sker fordelingen ikke udelukkende gennem værdilovens fordeling »bag om ryggen «.

Som afslutning på diskussionen af statskapitalismebegrebet overfor postkapitalismebegrebet, mener jeg at kunne fastslå, at kritikken af statskapitalismeopfattelsen henholder sig til en kapitalismeforståelse, der begrænser sig til fordelingsformerne, og derved ikke medreflekterer de samfundsmæssige forudsætninger for disse. Dette gælder såvel Damus, Rotermundt m.fl. som Ticktin. Selvom Heit og Mangeng også anvender postkapitalismetermen, har de ikke samme reducerede kapitalismeforståelse som de lige nævnte. En mulig forklaring på, at repræsentanter for postkapitalismeopfattelsen generelt insisterer på, at de nye samfundsmæssiggørelsesformer er uforenelige med kapitalisme, kan være deres baggrund i den tyske rekonstruktionslitteratur, hvori det er en central påpegning, at »værdiloven « ikke blot er en beregningsmåde, men en reelt fungerende samfundsmæssig reguleringsmekanisme. Værdireguleringen gennem udvekslingen bliver derfor det helt centrale for begribelse af den kapitalistiske reproduktionsform.

Kritikken af postkapitalismeopfattelsen har primært sigtet på dens reduktion af det kapitalismekarakteristiske til fordelingsforholdene, medens statskapitalismebestemmelsen er blevet fremhævet for at fastholde denne forudsætning: adskillelsen af produktion og behov. Men hvad betyder egentlig denne forskel for undersøgelsen af samfundene. Jeg mener, at det vigtige i forskellen er, at statskapitalismebestemmelsen fastholder et kapitalisme-kritisk perspektiv både overfor udviklingen $\mathrm{i} \varnothing$ st og vest. 
Hvad angår det første, så åbner statskapitalismeopfattelsen op for en forståelse af de sociale modsætninger, der udvikles i disse samfund. Når det grundlæggende samfundsmæssige forhold her er et kapitallønarbejder-forhold, betyder det, at der også udvikles krav til lønarbejdereksistensen f.x. ytringsfrihed, ret til selvstændig faglig organisering, ret til frit valg af arbejde og politiske krav om frie valg. Disse krav, der udspringer af lønarbejdereksistensens interesser, er i modsætning til partistatens fordring på politisk beslutningsmonopol. Dermed opstår der legitimeringsproblemer for det herskende styre. Dette implicerer en ideologisk modsætning i systemet: på den ene side produceres og reproduceres der eksistensbetingelser, der rejser krav om personlige, politiske og sociale rettigheder, og på den anden side må disse krav undertrykkes, da de er uforenelige med det eksisterende partiherredømme. Dette kan enten ske ved åben tvang eller ved opbygning af nye legitimitetsmønstre: som ved benægtelse af tilstedeværelse af emancipatoriske potentialer i den »konkurrence « kapitalisme (at fremstille den som tendentielt barbari), ved at bruge krigsfrygten til at skaffe opbakning om styret, eller ved forsikring om, at undertrykkelsen af befolkningsgrupper kun er temporær og nødvendig for en fremtidig frihed. Der er således tale om den paradoksale situation, at borgerlige rettigheder bliver til kritikpotentialer i samfundssystemer, der påstås at befinde sig på et højere »udviklingsniveau «. Men dette har selvfølgelig den »fordel «, at magthaverne kan stemple kritikken som kontrarevolutionær etc. Tilsvarende opfattes disse krav ofte kapitalismeapologetisk i de privatkapitalistiske lande, nemlig som krav om tilbagevenden til kapitalistiske produktionsforhold.

Pointen ved statskapitalismebegrebet er altså, at man fastholder, at kapitalismens modsætninger også genskabes i de krav som opposionelle og reformbevægelser fremfører. Som eksempel herpå kan nævnes, at Solidarnosc foruden at kræve retten til frie og uafhængige fagforeninger også - for at komme det ineffektive statslige bureaukrati til livs - rejste krav om markedsregulering af priserne, og om at virksomhedernes udvikling skulle reguleres gennem indbyrdes konkurrence. (Se: Opg $\varnothing-$ ret med den autoritære socialisme, København 1982) Både indenfor en overgangs- og postkapitalisme-forståelse kan sådanne krav kun forstås som et $\varnothing$ nske om tilbagevenden til kapitalismen. Jeg vil derfor hævde, at disse opfattelser blokerer for en forståelse af oppositions- og reformbevægelser i disse samfund, idet de ikke bestemmes som udtryk for modsætningerne i disse landes reproduktionsformer.

Den anden centrale pointe ved statskapitalismebegrebet er, at det fastholder en kritik af den kapitalistiske arbejderbevægelses socialismefor- 
ståelse. For Mattick er det en central pointe, at opfattelsen af socialisme som afskaffelse af privatejendom og markedets anarki er gældende både indenfor den socialdemokratiske og den partikommunistiske arbejderbevægelse, hvorfor hans kritik af disse ikke går på, at de har forrådt deres idealer, men at de idemæssigt er bundet af de kapitalistiske reproduktionsformer. (P. Mattick, Capitalism and Socialism, i: Root and Branch nr 10, 1981 ss. 17-19)

Dette udelukker dog ikke, at der er væsentlige forskelle dem imellem. Det er der, men denne forskel går på forholdet til det politiske demokrati. Medens socialdemokraterne opfatter det politiske demokrati som en gennemkæmpet rettighed i det borgerlige samfund - det der mangler er, at demokratiet ikke også omfatter $\varnothing$ konomien - så opfatter partikommunisterne det politiske demokrati i det borgerlige samfund primært som et skærmbræt for borgerskabets reelle politiske magt. ${ }^{17}$

17. Som den $\emptyset$ strigske socialdemokrat $\mathrm{O}$. Bauer allerede påpegede i 1920 , så skyldes socialdemokraternes kritik af forholdene i USSR ikke, at landet er socialistisk, men at det også er despotisk: »Det (USSR (m.a.)) er et socialistisk samfund, som er opstået. Thi sovjetmagten har fravristet kapitalisterne arbejdsmidlerne, befriet arbejdsprocessen fra kapitalens herredømme, frataget kapitalisterne rådigheden over arbejdsresultatet og organiserer nu selv ... en planmæssig, umiddelbar, samfundsmæssig fordeling af arbejdsresultatet. Men når det er socialisme, så er det dog en socialisme af særlig karakter, en despotisk socialisme.« (O. Bauer, Bolschewismus oder Sozialdemokratie?, Wien 1920 s. 62 f, her cit. fra W. Olle, op. cit. s. 133.) 


\section{Forord til »værdiformsanalytisk rekonstruktion«}

\section{Knud Pedersen og Thomas Stenderup}

I den strøm af engelsksproget litteratur om Marx' kapitalanalyse og specielt om Marx' værditeori, som er fremkommet i de seneste år ${ }^{1}$, er det foreliggende arbejde bemærkelsesværdigt derved, at det har rødder tilbage i den Vesttyske 'rekonstruktionsmarxisme', som også havde en kort glansperiode på de danske universiteter i 70erne. Artiklen udgør første del af Sydney-Konstanzgruppens (S-K) ambitiøse rekonstruktionsprojekt, som udover Marx' Kapitalanalyse omfatter analyse af konkurrence, stat, privatsfære, kultur, ideologi og kritisk videnskab².

Titlen på nærværende artikel er egentlig misvisende fsv. man forventer et overvejende filologisk studium af den 'autentiske' Marx. Mens 70ernes rekonstruktionsmarxisme havde et betydeligt filologisk islæt og i det hele taget sigtede på en blotlæggelse af indholdet i Marx' hovedværker, er ambitionsniveauet i S-K's projekt mere omfattende. Den indsigt, som blev oparbejdet i forbindelse med rekonstruktionsmarxismen, danner baggrund for intentionerne om en totalitetsteori for det borgerlige samfund. I udarbejdelsen af en sådan udgør Kapitalanalysen et vigtigt råmateriale, men den marxske analyses ufærdige, nærmest fragmentariske karakter - tillige med Marx' »metodologiske usikkerhed « (Backhaus) - nødvendigg ør iflg. forfatterne en betydelig reformulering af Kapitalanalysen som grundlag for en systematisk teori om den borgerlige samfundsform.

Foregribende indvendinger mod de temmelig markante afvigelser fra Marx, som præsenteres i nærværende og følgende artikler, hedder det på paroleform hos S-K: »I rekonstruktionsarbejdet - og med nødvendighed i udbygningsarbejdet - kan det ikke være et spørgsmål om sidestilling af Marx-citater eller blot gengivelse af Marx' argumentation, men om at udvikle en autonom tænkning, som - omend den i nogen grad trækker på Marx - må vurderes på egne fortjenester « ${ }^{3}$.

1. Udover de bøger og artikler, som er nævnt i artiklens note 1, kan nævnes: M. Lippi Value and Naturalism in Marx, London 1979. M. de Vroey »On the obsolescence of the Marxian Theory of Value: A Critical Review« in Capital \& Class 17, 1982.

Også det amerikanske tidsskrift Review of Radical political Economics har taget værdidiskussionen op i temanummeret 'Modern Approaches to the Theory of Value' URIE, vol 14 no 2; 1982.

2. Kurasje planlægger foreløbig at publicere 3 yderligere artikler, som sammen med den foreliggende udgør kapitalanalysedelen af S-K projektet.

3. M. Eldred »Critique of competetive Freedom and the State« p. 6. 
I deres intentioner om en totalitetsteori for det borgerlige samfund afgrænser S-K sig samtidig fra marxismetraditioner, som i Marx' hovedværker ser grundlaget for en historie- eller udviklingsteori ('Histomater'); dvs. både fra en teori om den progressive udvikling af klassesamfund (traditionel historisk materialisme) $o g$ fra en teori om udviklingen indenfor det borgerlige samfunds epoke, dvs. analysen af såkaldte objektive økonomiske eller andre 'bevægelseslove'. Heroverfor opstiller S-K programmet om én for hele det borgerlige samfunds epoke gyldig analyse af dette samfunds sociale relationers almene form.

Kodeordet i S-K's reformulering er formanalyse; en tilgang som jo ikke er $n y^{4}$, men som i S-K's udgave undergår en betydelig udvikling.

Både ældre og nyere fors $\emptyset \mathrm{g}$ på at udsondre de formanalytiske elementer hos Marx fremhæver ofte formanalysen som grundlaget for visse »kvalitative « aspekter i Marx' værditeori, hvorigennem denne kan adskilles fra specielt Ricardos ditto. Marx skulle således have udbygget Ricardos kvantitative arbejdsværdilære ved at tilføre værdibestemmelserne et »kvalitativt « indhold gennem undersøgelsen af vardiformen, og herigennem have besvaret det kritiske spørgsmål »hvorfor arbejdet ... giver sig udtryk i arbejdsproduktets værdi« (Rh1, 181 mod. $)^{5}$.

Efter denne opfattelse skulle det formanalytiske element altså være dét, som adskiller Marx fra sine klassiske forgængere (og neoricardianske efterfølgere), og som muliggør en overskridelse af den rent kvantitative, historieløse betragtning hos disse. Senest har imidlertid Backhaus' arbejder peget på, at de formanalytiske elementer i Marx'værditeori er alt andet end klare både hos Marx selv og hos hans fortolkere. Marx var iflg. Backhaus »metodologisk usikker«, hvilket bl.a. kom til udtryk i en stadig 'degenerering' af værditeorien i de successive fremstillinger, som Marx udarbejdede. I følge Backhaus kan den værdiformsanalytisk fortolkede værditeoris problem dog identificeres som et pengeproblem, hvorved værditeorien som pengeteori præsenterer sig som en kritik af pramonetar varditeori, herunder Ricardos arbejdsværdilære ${ }^{6}$.

4. Den formanalytiske læsning af Kapitalen kan formentlig føres tilbage til F. Petry »Der soziale Gehalt der Marxschen Werttheorie« (1916) og Rubins »Essays on Marx' theory of value « (1929). En række nyere bidrag kunne nævnes, men de har stort set alle samme svaghed (dvs. 'Marx-loyalitet') som ovennævnte, jvf. nedenfor.

5. Dette synes at være Marx' selvforståelse: Marx karakteristiske kommentarer til Ricardos fremstilling er, at den er »mangelfuld« (T 2, 196). Ricardo »focuserer ensidigt på værdistørrelsen« (T 3, 154). Ricardo har »fors $\varnothing \mathrm{mt} «$ at unders $\emptyset$ ge formen $(\mathrm{T} 3,154)$. »Den kvalitative side af sagen « er ikke udviklet hos Ricardo (T 3, 156). Etc.

6. Se Backhaus »Om forholdet mellem det 'logiske' og det 'historiske' i Marx' kritik af den politiske $\varnothing$ konomi $\ll$ in Kurasje 27/28. 
S-K tager denne tråd op, idet de påviser, at den som pengeteori konsekvent udarbejdede værdiformsanalyse er uforenelig med de arbejdsværditeoretiske elementer hos Marx: Værdiformsanalysen peger på det samfundsmæssige arbejdes aposterioriske karakter og udelukker derigennem enhver (herunder også en arbejdsværditeoretisk) apriorisk bestemmelse af værdien.

Opgivelsen af arbejdsværditeorien får selvsagt betydelige konsekvenser for den resterende kapitalanalyse, ligesom de traditionelle værditeoriproblemer (reduktionsproblemet, transformationsproblemet etc.) stiller sig i nyt lys, hvis ikke de endegyldigt aflives. Dette skal dog ikke berøres nærmere her.

Hvor Backhaus' arbejder har kastet nyt lys over Marx' »metodologiske usikkerhed « og herigennem på indholdet i problematikken vedrørende forholdet mellem logik og historie, forekommer S-K-projektet, som i høj grad er inspireret af Backhaus, at være et vigtigt bidrag til udviklingen af en formanalytisk kapitalismeanalyse. Gennem afvisningen af den strengt logiske immanente deduktion af begreber og gennem udfoldelsen af den Glaser-inspirerede 'dialogdialektik' ${ }^{7}$, hvor begreberne udvikles i et stadigt 'samspil' mellem den umiddelbare erfaring/bevidsthed og reflektionen heraf, forekommer det, at S-K har fået tilført formanalysen et indhold, der gør det muligt at tale om en »udlæsningsstrategi« som metodologisk alternativ til traditionel samfundsvidenskab. Backhaus' 'naive' spørgsmål om, hvorvidt det »lader sig afgøre, om en bestemt struktur er blevet 'lastud' af et bestemt fænomen eller omvendt er blevet laest ind i det? $^{8}$ er jo ikke mere naivt end det er afslørende for den kendsgerning, at marxistiske traditioner frem til idag har haft samme 'empiritroskabsproblemer' som de, den traditionelle samfundsvidenskab er blevet tillagt. S-K-projektet gør ikke krav på at have løst ethvert metodologisk og teoretisk-indholdsmæssigt problem for en totalitetsteori om det borgerlige samfund. Men det peger i en bestemt retning for at frugtbargøre de idag så udskældte filologiske kapitalrekonstruktionsstudier.

Oversættelsen af den engelske tekst har voldt visse vanskeligheder. Dels er der ikke rigtig nogen tradition for oversættelse af engelske tekster indenfor genren, dels har den Hegel-inspirerede metodologi, som S-K trækker på, ingen særlig tradition herhjemme, og endelig nødvendiggør

7. Se note 2 i artiklen nedenfor.

8. Backhaus op.cit. p. 164. 
S-K's reformulering af centrale marxske begreber brug af termer, der markerer en afvigelse fra de gængse marxske. Disse forhold har resulteret i, at vi i oversættelsen har anvendt visse termer/konstruktioner, som kan virke noget uvante, men som på den anden side skulle markere ét af ovennævnte forhold.

\section{Forkortelser}

\section{Marx}

Rh 1, Rh 2, Rh 3: Kapitalen, bd. I, II og III Kbh. 1970.

K1, K2, K3: Das Kapital, bd. I, II og III in Marx-Engels Werke Berlin, bd. 23, 24 og 25.

Btk: Bidrag til kritikken af den politiske фkonomi Kbh. 1974.

Z: Zur Kritik der Politischen Ökonomie in MEW 13

Gr: Grundrids til kritikken af den politiske фkonomi Århus 1977.

G: Grundrisse der Kritik der politischen Ökonomie (Rohentwurf) 1857-58, Berlin DDR 1953.

T1, T2, T3: Teorier om mervardien bd. I II og III Kbh. 1979.

TM1, TM2, TM3: Theorien über den Mehrwert Bd. 26.1, 26.2 og 26.3 MEW.

B: Briefe über das 'Kapital' Berlin DDR 1954.

\section{Andre}

DgV: Roth/Kleiber/Hanlon/Eldred, Die gedoppelte Verdopplung. Zum Ausbau des Marxschen Systemfragments; udkommer.

RVfA: Eldred/Hanlon, 'Reconstructing Value-form Analysis' in Capital \& Class nr. 13 1981.

VRAK 1-4 (RVfA 1-4): Værdiformsanalytisk rekonstruktion af Kapitalen, del 1-4. Publiceres i Kurasje.

CCF\&S: Eldred, Critique of Competitive Freedom and the State: Outline of an Extension to Marx's Uncompleted System'; upubliceret 1981. 


\title{
Værdiformsanalytisk rekonstruktion af Kapitalen
}

\author{
Michael Eldred, Marnie Hanlon, \\ Lucia Kleiber og Mike Roth
}

\section{Introduktion}

Lige siden udgivelsen af Engels' udgave af Marx's Kapitalen, er dette værk blevet udsat for kritik af dets begrebslige fundering: værditeorien. Bitterheden i denne kritik af »arbejdsværditeorien«, startet af BöhmBawerk og kontinuerligt gentaget frem til idag (eks. Lippi, Steedman), kan kun måle sig med graden af u enighed i fortolkningen af værditeorien. I Rubins tidlige fortolkning af værditeorien optræder kvalitative elementer, som på ingen måde kan reduceres til en arbejdsværditeori af den gængse »ricardianske« type. Kontroversen omkring versioner af værditeorien fortsætter også idag i den marxistiske sekundærlitteratur ${ }^{1}$.

Stormløbet mod arbejdsværditeorien fra neo-ricardiansk sraffa'sk side (hvis kendteste repræsentant måske er Steedman), har for mange totalt miskrediteret den ortodokse arbejdsværditeori. Næsten uden undtagelse peger de nyere forsvarere af Marx' kritik af den politiske økonomi på Marx's værdiformsanalyse som værditeoriens væsentligste træk, idet de påpeger at værdiformsanalysen forbliver uberørt af kritikken af den kvantitativt fortolkede $»$ værdilov«. Imidlertid forsøger de fleste forsvarere (f.eks. alle bidragene i Elson 1979) at korrigere Marx’s fremstilling af værditeorien uden at sige farvel til dens ricardianske elementer. Disse elementer består i opfattelsen af, at menneskeligt arbejde, slet og ret, danner værdisubstansen, og at denne substans kan anvendes som kausal forklaring på varernes udvekslingsforhold. Der kan findes mange passager hos Marx, som kan tages til indtægt for en sådan fortolkning af værdisubstansen. Ligeledes er der passager, som understreger den uløselige sammenhæng mellem værdisubstans og værdiform.

1. Nyere engelsksproget litteratur, som delvist opsamler debatten i det engelske tidsskrift Capital \& Class, er D. Elson (ed.) Value: The Representation of Labour in Capitalism (London 1979) og Steedman et al. The Value Controversy (London 1981). Den japanske Uno-skole har foreslået en rekonstruktion af værditeorien; se K. Uno Principles of Political Economy: Theory of a Purely Capitalist Society (Sussex 1980) og M. Itoh Value and Crisis (London 1980). Deltagerne i den franske debat inkluderer J. Cartelier, C. Benetti og M. de Vroey. Den tyske debat inkluderer bidrag fra U. Krause Money and abstract Labour (London 1981; Tysk udgave Geld und abstrakte Arbeit Frankfurt 1979. Dette arbejde indeholder en omfattende bibliografi), Backhaus, Steinvorth, Nanninga, Göhler (Die Reduktion der Dialektik durch Marx, Stuttgart 1980 indeholder også en omfattende bibliografi), Peter Ruben, Glaser, Roth, Reichelt, Hartmann. 
Sådanne passager optræder især i forbindelse med Marx’s argumentation for penge som en nødvendig form for værdi. Hvis den marxske værditeori fortolkes som væsentligst ricardiansk, forbliver forbindelsen til den marxske pengeteori et mysterium. Fremfor alt har Backhaus's arbejder peget på den esoteriske værditeori i Marx's tekster. Denne kan kun fortolkes som en kritik af præmonetære værditeorier. Den esoteriske, værdiformsanalytiske argumentationskæde må graves frem af den eksoteriske arbejdsværditeori, som er éns umiddelbare indtryk af Kapitalen, bind 1. At den esoteriske version af værditeorien forbliver skjult for nybegynderen er på ingen måde overraskende, eftersom Marx i de efterfølgende versioner af værditeorien, som han udgav, fors $\varnothing$ gte at »popularisere mest muligt« $(\mathrm{Rh} 1,91 ; \mathrm{K}, 11)$. Det er derfor ikke underligt, at visse personer inden for den marxistiske tradition, anser værdiformsanalysen for at være »rokokoornament« (Luxemburg).

Vi er enige-med Böhm-Bawerk i den vurdering af Marx's hovedværk, at det står og falder med dets begrebslige grundlag, værditeorien. Det er samtidig vores opfattelse, at det store flertal af Marx's forsvarere, selv om de fremhæver den grundliggende betydning af værdiformsanalysen, holder fast ved uholdbare elementer i den marxske fremstilling. I stedet har vi besluttet at rekonstruere Marx's værditeori fundamentalt ved at skille værdiformsanalysens (guld-)korn fra den ricardianske værditeoris avner. Resultatet er blevet en sådan reformulering af værdibegreber, som næppe ville være indlysende ved første læsning af Marx. Rekonstruktionen af de første begreber (værdisubstans, værdiform, værdiudtryk, penge, værdistørrelse) har videre nødvendiggjort, at man påny gennemtænker alle systematiske trin i Marx's udkast til de tre bind i Kapitalen. Denne gennemtænkning har ført os til visse, umiddelbart overraskende, kætterske resultater (f.eks. kritik af de marxske begreber om »arbejdskraftens værdi«, om »overførsel af værdi «, om »realisering af værdi «, om hele revenueformsanalysen). Ikke alene varierer vores rekonstruerede kapitalanalyse fra Marx i dens systematiske orden (f.eks. placeringen af renteanalysen i produktionsprocesanalysen), men også i dens begrebers selvstændige indhold (f.eks. forsvinder det såkaldte »transformationsproblem « og »reduktionsproblemet«, ligesom begrebet om »kompliceret arbejde« får et helt nyt indhold).

Rekonstruktion af den marxske kapitalanalyse er ikke det endelige mål for vores teoretiske arbejde. Ligesom Marx planlagde kapitalanalysen som første del af et mere omfattende teoretisk system for det »borgerlige samfund «, intenderer vi at udvikle et sådant. Før vi vender os mod dette, vil vi imidlertid kommentere dén metodologiske fremgangsmåde, som har været ledetråd for vores arbejde. 


\section{Dialektisk metode som en kritisk dialog med umiddelbar erfaring².}

Udarbejdelsen af en fremstilling, forskningsprocessen, er forsøget på at nå frem til en vellykket fremstilling. Hvad er den passende målestok for 'vellykket'? Ved starten på den systematiske fremstilling har vi fortaleren for den dialektiske teori og opponenten, som har en praktisk umiddelbar erfaring om livet i et nutidigt borgerligt samfund. Fortaleren inddrager elementer af denne umiddelbare erfaring i udarbejdelsen af analysens første begreber. Hermed fornægter fortaleren ikke opponentens umiddelbare erfaring; han/hun hævder kun - hvilket er uundværligt ved opbygningen af systemet - at være i stand til at afgøre, på hvilket systematisk trin den umiddelbare bevidstheds indhold og argumenter kan udspilles.

I den opbygning af fremstillingens første begreber, der foregår gennem reflektion over elementer af den umiddelbare erfaring indvarsles analysens sprog. Opponenten, som har fulgt opbygningen af disse begreber, må nu fortsætte dialogen med fortaleren (oftest: den skrevne tekst, eller: en marxistisk universitetslærer), idet han/hun tager hensyn til det analysesprog, som er udviklet hidtil. De indvendinger, der formuleres nu, må antage deres passende form som begrebsligt artikulerede indvendinger. Hermed løftes naturlig bevidsthed ud over dens umiddelbarhed - den bliver gebildet - og aufgehoben. Umiddelbar erfaring tages gradvist op, og opløses i den systematiske fremstilling uden at være blevet negeret. Målet med systematisk tænkning er at udarbejde et kendskab til den indre forbindelse mellem den samfundsmæssige totalitets borgerlige form og umiddelbar bevidsthed. Fremstillingen afsluttes, når den borgerlige samfundstotalitets almene fænomener har fundet en plads i fremstillingen, således at disse er begrebsliggjort til opponentens tilfredshed. Fænomenernes almenhed betyder deres historisk specifikke gyldighed for en hel historisk periode, karakteriseret ved en $\emptyset$ konomisk proces, som er formidlet af og domineret af varers og penges bevægelser som kapital. Denne almenhed kan selv blive et diskussionspunkt, når det hævdes, at en given kapitalistisk udvikling har ført til et nyt stadium, hvor de begreber, der vedkom foregående stadium ikke længere har gyldighed. Fortalerens opgave er at argumentere for eksistensen af sådanne almengyldige forhold, som angår aspekter af den samfundsmæssige realitet og som, skønt iklædt nye gevandter, er nærværende i hele denne historiske periode. Systematisk tænkning fornægter på ingen måde de enorme ændringer,

2. Vores metodologiske konception trækker på et arbejde af den Lorenzen-inspirerede Ivan Glaser, som i formuleringen af en dialogisk konception af den dialektiske metode forsøger at trække på passager fra forordet til Hegels Phänomenologie des Geistes. Se Glaser 'Dialektisches Denken und natürliches Bewusstsein' in Lorenzen Festschrift V. Berlin 1978. 
som er en del af det kapitalistiske samfunds dynamik. Den forsøger faktisk at begrebsliggøre grundlaget for den »evige usikkerhed og bevægelse«, som den lokaliserer i kapitalistisk teknologi. Ikke desto mindre er det muligt at pege på visse fundamentale karakteristika ved det borgerlige samfund, som på den ene eller anden måde har været genstand for reflektion i hele den moderne periode så langt tilbage som til Hobbes. Disse socio-filosofiske emner bevarer deres relevans for den tænkning, der er inspireret af Marx's kritik af den politiske økonomiuanset de slående, kontinuerte forandringer i fænomenernes iklædning i det postfeudale samfund. Det må også fastholdes, at kritikken af det borgerlige samfund på ingen måde er irrelevant i relation til de samfund, der sædvanligvis karakteriseres som socialistiske. For Østblokkens samfund rejser sig spørgsmålet om, og i hvilken form, samfundet er blevet subjekt for sin egen materielle reproduktion. Disse samfund er selv indflettet $\mathrm{i}$ den dominerende kapitalistiske $\varnothing$ konomiske og politiske orden. Deres samfundsmæssige struktur er en ren og skær parodi på Marx's 'fri sammenslutning af producenter'.

Eftersom systematisk viden ikke umiddelbart er tilgængelig for umiddelbar bevidsthed, men først resulterer af den systematiske dialog, er dialektisk tænkning en kritik af umiddelbar bevidsthed. Dagligdagens tænkemåder, som er adækvate i forhold til det praktiske liv, vises at være partielle i den forstand, at de omfatter en begrænset konstellation af fænomener, eller de er falske i den forstand, at de forfægter en sammenhæng, som tager de nuværende former for samfundsmæssig objektivitet for givne. Dagligdags tænkning er således fanget af de givne sociale relationer, som den dialektiske tænkning, med sin specielle procedure, søger at overskride. Ved at demonstrere at det borgerlige samfund er funderet i en specifik form for samfundsmæssiggørelse af arbejdet formidlet af ting, og at denne form er modsætningsfyldt med deraf følgende negative konsekvenser for en række aspekter af det borgerlige, sociale liv, fremviser den dialektiske tænkning de punkter, hvor den praktiske kritik må begynde for historisk at overvinde disse modsætninger. Ledetråden for kritikken af det borgerlige samfund er begrebsligg ørelsen af et samfund i hvilket samfundsmedlemmerne i fællesskab ikke er subjekt for deres egen materielle reproduktion. Den ideologiske kamp, som finder sted, er antagonismen mellem på den ene side repræsentanter for det $\varnothing$ konomiske livs »hårde facts «, for »tingenes tvang «, for »det realistiske«, som ikke ser andre måder at organisere det sociale liv på, og for apolegeterne, der fremhæver de borgerlige friheder som supplement til det påståede gunstige system af privat erhvervsliv, og på den anden side de, som på forskellig måde fremviser negative 
sider af borgerlig, social erfaring. Om kritikerne sætter fingeren på netop det punkt, som må blive omdrejningspunktet for praktisk politisk aktivitet, er et stridsspørgsmål. Dialektisk tænkning argumenterer for et specifikt kritikpunkt af kapitalismen og for nødvendigheden af at opbygge en helt ny totalitet af samfundsmæssige former. Ved at gøre dette, kritiseres naiv kritisk bevidsthed, som alene retter sig imod én side af negativ, social erfaring, eller som fejlidentificerer grundlaget for praktisk politisk aktivitet (f.eks. ved kun at rette angreb mod »storkapital«).

Referencen til en 'borgerlig totalitet' indikerer allerede, at en kritisk samfundsteori ikke kan begrænse sig til en kritik af kapitalistisk økonomi. Vi fortsætter derfor med nogle bemærkninger om andre områder, som er genstand for teoretisk samfundsmæssig kritik.

\section{Udfoldelse af Marx's fragmentariske system}

Specielt efter publikationen af Rosdolskys, Schwarz's og Wygodski's arbejder $^{3}$ er det velkendt, at Marx’s kritik af politisk økonomi kun er en del af et oprindeligt mere omfattende »borgerligt økonomisk system « (Marx til Lasalle 22.2.1858), omfattende »6 bøger. 1) Om kapital (indeholder nogle indledende kapitler), 2) Om jordejendom, 3) Om lønarbejde, 4) Om staten, 5) International handel, 6) Verdensmarked « (ibid.). Vi har ikke her i sinde at undersøge i hvilket omfang Marx faktisk udførte eller ændrede planen for sit system, som den oprindelig blev publiceret ${ }^{4} \mathrm{i}$ det berømte 1859 Forord. Dette ville kræve sin egen filologiske unders $\emptyset$ gelse. Her skal blot gøres nogle bemærkninger om det forskningsprogram, som er vokset ud af vores arbejde med Marx's $\varnothing$ konomiske tekster. Uanset de nye indsigter, som måtte vindes i fremtidige filologiske undersøgelser af Marx's tekster, må man konkludere, at Marx's teoretisk-kritiske projekt,

3. R. Rosdolsky Kapitalens tilblivelseshistorie, Århus 1977, W. Schwarz 'Das Kapital im allgemeinen und die Konkurrenz im ökonomischen Werk von Karl Marx. Zu Rosdolskys Fehlinterpretation der Gliederung des KAPITAL' in Gesellschaft: Beiträge zur Marxschen Theorie Nr. 1, Ff.M. 1974, W.S. Wygodski Die Geschichte einer grossen Entdeckung Ø. Berlin 1967.

4. Så tidligt som 1844 annoncerer Marx i forordet til Økonomisk-filosofiske skrifter et endnu mere ambitiøst projekt end dét, som blev planlagt under udarbejdelsen af Grundrids. Afgjort ikke$\emptyset$ konomiske temaer nævnes: »Jeg vil derfor i forskellige, uafhængige hæfter successivt publicere kritikken af ret, moral, politik etc. og som konklusion fors $\varnothing \mathrm{ge}$ at forbinde det hele, relationen mellem de enkelte dele samt endelig kritikken af den spekulative behandling af dette stof. Af denne grund formuleres forbindelsen mellem nationaløkonomi og stat, ret, moral, borgerligt liv etc. kun forsåvidt nationaløkonomien selv formulerer disse emner ex professo« (Ökonomisch-philosophische Manuskripte Leipzig 1970, p. 87). Marx opgiver dette projekt efter at have genlæst Hegels Rechtsphilosophie (se 1859-Forordet). 
uanset hvorledes dette projekt fortolkes, forbliver ufærdigt ${ }^{5}$; faktisk blot et skelet. Selv skelettet blev efterladt som en torso ${ }^{6}$ - nemlig de to publicerede hæfter Bidrag til kritik af den politiske фkonomi og Kapitalen, bind I (hvor Marx selv forberedte udgivelsen af to tyske og én fransk udgave) - og »armene og benene « af en mængde upublicerede manuskripter ${ }^{7}$, fra hvilke Engels udgav bind 2 og 3, samt manuskripter til den historiske præsentation af teorien, Teorier om mervardien. Hvad angår $» k \varnothing d$ og blod « af den planlagte analyse af det borgerlige samfunds overbygning, som der hentydes til i det velkendte 1859-Forord med ordene »den sociale, politiske og åndelige livsproces « $(\mathrm{Rh} 1,13)^{8}$, er end ikke en systematisk skitse efterladt af Marx. Planen om 6 bøger antyder nærmest et $\varnothing$ konomisk arbejde. Marx intenderede $» i$ de sidste tre (bøger) hovedsagelig kun at give grundtrækkene« (Marx til Lasalle 11.3. 1858; B 87). I et brev til Kugelman 4 år senere beretter Marx om en ændring af publikationsplanerne og refererer til »udviklingen af de følgende dele, som (med undtagelse måske af relationen mellem de forskellige statsformer og samfundets forskellige $\varnothing$ konomiske strukturer) nemt kunne udføres på basis af det allerede udviklede« (28.12. 1862; B 113).

Vores rekonstruktion af kapitalanalysen har tilført en teori om det borgerlige samfunds overbygning nye perspektiver. Kodeordet i vores tilgang er 'formanalyse', ikke kun med hensyn til de forskellige værdiformer som konstituerer kapitalistisk økonomisk objektivitet (Wertformgegenständlichkeit), men også i forhold til de bevidsthedsog praksisformer samt former for samfundsmæssige institutioner, som nødvendigvis komplementerer den $\varnothing$ konomiske formbestemthed (Formbestimmtheit). Idet vi kritiserer og opgiver arbejdsværditeorien

5. Se Rosdolskys diskussion af Marx’s plan og ændringerne heri, in: Rosdolsky op.cit. pp. 10-56. De syv varianter af denne plan gives i oversigtsform i Wygodski op.cit. pp. 114-7.

6. Se I. Glaser Warum Marx' Kapital ein Torso blieb Habilitationsschrift Uni. Konstanz 1980, hvor en radikal tese vedr. Kapitalens fragmentariske karakter præsenteres og forsvares.

7. Vanskelighederne ved at frembringe en version af Marx's kapitalanalyse, som kan betragtes som et afsluttet arbejde, er faktisk uoverstigelige. Manuskripternes ufærdige karakter - ikke mindst det vigtige manuskript til bind 3 skrevet i 1864-65 - fremgår tydeligt i et brev fra Marx til Engels, skrevet på et tidspunkt, hvor manuskriptet til bind 1 blev forberedt til udgivelse: »Selvom det er færdigt, kan manuskriptet, i dets nuværende enorme omfang ikke udgives af andre end mig selv, selv ikke af dig« (13.2. 1866, B 130). Som bekendt blev Engels, på trods af denne advarsel, Marx’s udgiver.

8. Det kan med rette diskuteres hvorvidt Marx nogensinde planlagde en sådan analyse som et tema i hans 'borgerlige økonomiske system'. Uanset dette filologiske fortolkningsproblem er det klart, at de berømte formuleringer om, at den samfundsmæssige væren bestemmer bevidstheden, forbliver tomme og indholdsløse uden den teori, som begrebsligg ør borgerlig 'samfundsmæssig væren' og 'bevidsthed' og sammenhængen herimellem. Althusser-marxismen, som er det hidtil mest indflydelsesrige fors $\emptyset \mathrm{g}$ på at give disse indholdsløse påstande i 1859-Forordet mening, kritiseres berettiget for meningsløsheden i udtryk som 'i sidste instans' og 'relativ autonomi'. 
som en teori om et væsen skjult bag de økonomiske former - et væsen som kausalt forklarer deres kvantitative bestemthed - opgiver vi samtidig at være i stand til at udarbejde objektive »bevægelseslove « for $\varnothing$ konomien eller for statens relation til den (i skikkelse af $\varnothing$ konomisk politik). Den indsigt, som vi påstår kan funderes i værdiformsanalyse, er, at der ikke er mulighed for at udarbejde forudsigende love om de $\emptyset$ konomiske bevægelser i et samfund, hvor samfundsmæssigt arbejde kun forefindes a posteriori. Det værdiskabende arbejdes aposterioriske karakter forklarer den radikale forskel mellem samfundsvidenskab og naturvidenskab. En kritisk videnskab om det borgerlige samfund, som ikke begrænser sig til en empirisk Erfahrungswissenschaft, søger at demonstrere tilfældigheden og tvangen i en proces, der sætter sig selv igennem »bag ryggen « på producenterne - ikke at opdigte såkaldte objektive bevægelseslove som, i lighed med Newtons love, ville forklare himmellegemernes synlige bevægelse med simple, fundamentale principper. Marx og Engels var begge stadig imponeret af naturvidenskaben i deres opfattelse af samfundsvidenskab ${ }^{9}$.

En formanalytisk rekonstruktion af kapitalanalysen tjener som begrebsligt fundament for en teori om den kapitalistiske $\varnothing$ konomis fænomener og det borgerlige samfunds overbygning. Strukturen i det totale system, hvis teoretiske genstand er totaliteten af den borgerlige samfundsform, er som følger

I Varer og penge.

II Kapital-lønarbejde relationen og kapitalistisk produktion.

III Rente og revenueformerne.

IV Kapitalens cirkulations- og reproduktionsproces.

V Den kapitalistiske økonomis fænomener: Den konkurrencesatte frihed og tvang.

VI Staten som Leviathan.

9. Marx citerer bifaldende en russisk kritikers anmeldelse af bind I: »Marx betragter samfundets bevægelse som en naturhistorisk proces, der styres af love, som ikke blot er uafhængige af menneskets vilje, bevidsthed og hensigter, men tilmed selv bestemmer dets vilje, bevidsthed og hensigter« (Rh 1, 103; K1, 26). Han taler om »samfundsmæssig nødvendig arbejdstid .... som en regulerende naturlov .... ligesom tyngdeloven« $(\mathrm{Rh} 1,175 ; \mathrm{K} 1,89)$. Engels sammenligner Marx's formuleringer af merværditeorien med opdagelsen af ilt og miskrediteringen af Flogistonteorien i det 18. århundrede $(K 2,22)$. Althusser bruger i høj grad Flogistonteori-sammenligningen i Reading Capital (London 1970) i sin argumentation for en bestemt fortolkning af Marx. I følge denne fortolkning var Marx's værditeori, og i særdeleshed kategorien 'værdi af arbejdskraften', en revolutionerende 'landevinding' (op.cit. 29) for den politiske økonomi, ligesom Lavoisier's opdagelse af ilt var det for naturvidenskaben. »Marx fremstår således som grundlægger af en videnskab ('Historievidenskaben', EHKR), på linie med Galilæi eller Lavoisier« (op.cit. 153). Dette aspekt af Althussers Marxfortolkning gjorde Marx tilgængelig for ivrige anglosaksiske videnskabsteoretikere i 70erne. 
VII Borgerlig subjektivitet og privatliv.

VIII Staten som udtryk for borgernes vilje: Borgerligt offentligt liv og demokrati.

IX Kultur og æstetisk erfaring.

X Ideologi og kritisk videnskab.

De første 4 overskrifter dækker strukturen i en bearbejdet kapitalanalyse. Den femte overskrift omhandler analysen af det økonomiske livs fænomener samt bevidstheds- og handlingsformer for subjekter, som stræber efter at opnå indkomst med deres private ejendom. Afgørende for konkurrenceanalysen er derfor begrebet om privat ejendom, som udvikles fra værdiformskategorierne i kapitalanalysen. Den konkurrencemæssige kamp om indkomst og derfor om fordelingen af samlet samfundsmæssig varerigdom, hvis resultat altid er uforudsigeligt, hviler uundgåeligt på værdiformernes tilfældighed, som tillader store kvantitative variationer. Individerne er således underlagt den samlede, subjektløse $\emptyset$ konomiske proces. Denne $\varnothing$ konomiske proces er på sin side domineret af en iboende modsigelse i relationen mellem pengekapital og arbejdskraft. Kapitalens første princip - udbytningen af arbejdskraften - finder dets tvingende grænse i den endelige, til rådighed værende arbejdskraft. Den periodiske udrensning af overflødig kapital funderer den nødvendige skelnen mellem succesfulde og ikke-succesfulde konkurrencesubjekter. Begrebet om de ikkesuccesfulde tilvejebringer på sin side én af de begrebslige overgange til staten som et subjekt, der intervenerer i og sikrer konkurrencesamfundets form. Det almene samfundsmæssige subjekt, staten, modsvares af det særegne individ, som søger sin lykke i en privat sfære, afsondret fra kampen for levebrød. Det private subjekt er konfronteret med friheden til og nødvendigheden af at skabe en privat eksistens (et privat liv) for sig selv indenfor rammerne af objektive muligheder. Dette, at nydelsen af det private liv bl.a. beror på den succes, som det private subjekt kan opnå i det konkurrencemæssige liv, er basis for den frygt, som plager det private subjekt. Med undertrykkelsen af denne frygt fremkommer det succesfulde subjekt, som har forudanelse om meningsløsheden ved et roligt sikkert liv, som kun kan opnås ved at gøre sig selv usårlig i forhold til det borgerlige sociale livs modsigelser. Ængstelse og forstillelse er to komplementære former, i hvilke subjekterne tilpasser sig deres fremmedgjorte sociale liv. Denne fremmedgørelse formodes at blive overvundet af borgernes deltagelse i offentligt liv, hvilket influerer på statens ageren - staten som det højeste sociale subjekt. Statens impotens overfor den $\emptyset$ konomiske proces og, specielt, overfor verdensmarkedet minder igen subjekterne om deres henvisthed til en subjektløs proces. Politikerne og økonomerne, hvis op- 
fattelser $\varnothing v e r$ indflydelse på statens interne og eksterne strategi, baserer deres forslag på det selvbedrag, at den samlede $\varnothing$ konomiske proces, hvis krampetrækninger ligner en vildhests utæmmelige krumspring, kan styres i henhold til fælles menneskelige intentioner. De indflydelsesrige ledere holder, trods deres tilsyneladende selvsikkerhed, i virkeligheden bare igen i tøjlerne på en grusom død.

Med de foranstående bemærkninger, som ikke gør krav på videnskabelig strenghed, intenderer vi at antyde noget af dét, som kan gøres begrebsligt tilgængeligt gennem dialektisk tænkning. Vore vidtrækkende teoretiske intentioner er begrundet i fors $\emptyset$ get på gradvist at konsolidere vore systematiske reflektioner over conditio humane i den borgerlige epoke - indtil de får et udseende, der kan publiceres. Strukturen af det rids, som er givet ovenfor, vil blive udviklet - og uden tvivl ændret i det fortsatte arbejde.

\section{Det foreliggende papir}

Den analyse af varer og penge, som præsenteres her, er en let revideret version af et papir, som blev publiceret i Melbournetidsskriftet Thesis $11^{10}$. Det papir er på sin side en revision af et papir, som tidligere er blevet publiceret af to af os i det engelske tidsskrift Capital \& Class $^{11}$. I sidstnævnte papir gives en detaljeret kritik af Marx's fremstilling i Kapitalen, bind 1, kap. 1, som ikke gentages her. Det kan være en støtte for læseren at supplere med den mere udstrakte fremstilling i den tidligere artikel, som også indeholder kritiske kommentarer til nogle af Marx's fortolkere (Mandel, Rosdolsky, Elson, Engels, Rubin). Marx's behandling af værdistørrelsen i Bidrag til kritikken af den Politiske Økonomi - der som vist af Backhaus ${ }^{12}$ indeholder en mere succesfuld og konsistent dialektisk argumentation bliver kritiseret i den foreliggende artikel i et tillæg (§ 8). Ligeledes har vi benyttet lejligheden til at unders $\varnothing$ ge to nyere fortolkninger af værditeorien i Kapitalen af Kozo Uno og af Cutler, Hindess, Hirst og Hussain. Vi finder begge arbejder sørgeligt utilstrækkelige i deres betragtninger over den marxske formanalyse; førstnævnte fordi værdiform her adskilles fra værdisubstans, sidstnævnte fordi de formanalytiske betragtninger fuldstændig negligeres. Da de sidstnævnte forfattere lægger vægt på problemet med at

10. Thesis 11, nr. 41982.

11. Eldred/Hanlon 'Reconstucting Value-form Analysis' in Capital \& Class, nr. 13 1981; Kleiber/ Roth Kapitalismus, Privatheit, Staat Mimeo Uni Konstanz 1979.

12. Se især H.G. Backhaus 'Zur Dialektik der Wertform' in A. Schmidt (ed) Beiträge zur marxistischen Erkenntnistheorie Frankfurt 1969 (engelsk oversættelse i Thesis 11 nr. 1 1980); 'Materialen zur Rekonstruktion der Marxschen Werttheorie 4' (upubliceret) og 'Om forholdet mellem det »logiske« og det »historiske« i Marx's kritik af den politiske økonomi' in Kurasje 27/28 Viborg 1981. 
begrebsliggøre de forskellige pengetyper, har vi i et tillæg ( $§ 9 b)$ skitseret udviklingen af andre pengetyper end guld-penge.

\section{Værdiformsanalytisk rekonstruktion af Kapitalen. Del 1.}

$\S 1$.

Et kendetegn ved vores nuværende samfund er, at en overvældende del af produkterne er produceret industrielt, og at de antager vareform. Den systematiske analyse af samfundets borgerlige form og specielt af den kapitalistiske $\varnothing$ konomi starter med at fokusere på de industrielle arbejdsprodukter, som er varer.

»I de samfund, hvor den kapitalistiske produktionsmåde hersker, viser rigdommen sig som en 'uhyre vareophobning' og den enkelte vare som dens elementarform. Vor undersøgelser begynder derfor med en analyse af varen« (Rh1, 128; K1, 49). Vi ser den systematiske betydning af Marx's analyse af varer og penge i begrebsliggørelsen af vardiformen. Det forekommer os derfor misvisende at fremhæve 'den enkelte vare' som udgangspunkt for analysen. »Hvor skal analysen begynde? Ved begyndelsen af analysen af kapitalismen må der refereres til »det hele«, men til dette kan der ved begyndelsen kun refereres, sådan som det fremtræder: Kapitalistisk rigdom som en vareophobning. Startende hermed kan Marx artikulere sin første opgave som analysen af varen $\aleph^{13}$. Hvilke varer er indbefattet $\mathrm{i}$ industrielle varer, som udgør analysens udgangspunkt? Både genstandsmæssige produkter (f.eks. en flyvemaskine) og processuelle varer (f.eks. en færgerejse), råvarer (f.eks. olie) og behandlede varer (f.eks. en plastikpose), ligesom også landbrugsvarer, produceret ved hjælp af maskiner, medregnes.

$\S 2$.

Vi fokuserer på industrielle varer som de optræder på markedet med deres prissedler. Formidlet af potentielle salg står de industrielle varer i en udvekslingsrelation. Analysens første skridt er at undersøge varernes almene udvekslingsrelation. Pengenes formidling af udvekslingen er i første omgang holdt ude (ausgeblendet), idet kun kombinationen af potentielle købs- og salgsrelationer - hvorigennem varen viser sit medlemskab af vareverdenen - betragtes. Varerne bliver således i første omgang systematisk betragtet som pramonetcere varer. Varernes relation til hinanden kan skrives som det udfoldede udvekslingsskema:

13. Mike Rot Kernstruktur unserer Kapitalistischen Gesellschaft Athenäum Frankfurt a.M. 1972, p. 11. 
x vare A kan udveksles med $\left\{\begin{array}{l}\mathrm{y}_{1} \text { vare } \mathrm{B}_{1} \\ \mathrm{y}_{2} \text { vare } \mathrm{B}_{2} \\ \\ \\ \mathrm{y}_{\mathrm{n}} \text { vare } \mathrm{B}_{\mathrm{n}}\end{array}\right.$

For en given vare A er vareverdenens $\emptyset$ vrige varer, med hvilke den kan udveksles, dens byttevardier. $\mathrm{x}, \mathrm{y}_{1}, \mathrm{y}_{2}$. .betegner kvantiteter af varerne $\mathrm{A}, \mathrm{B}_{1}$, $\mathrm{B}_{2} \ldots$, målt i passende enheder. Med henblik på analysen af værdiformen er disse kvantiteter imidlertid uden betydning og udvekslingsrelationen kunne lige så vel skrives uden dem.

Samtidig med at vi i § 1 inddrog dagligdags kendte genstande i fremstillingen, foretog vi også en begrcensning af den analytiske behandling, nemlig til industrielle varer. Omnis determinatio est negatio. På samme måde er pengenes formidling af udvekslingen holdt ude for at nå analysens første begreb: udvekslingsrelationen. Udvekslingsrelationens systematiske oprindelse (idet penge holdes ude) betyder, at dette begreb afviger fra en dagligdags-(ofte historicerende) forståelse af udveksling. Iffg. en umiddelbar opfattelse af udveksling skifter de udvekslede ting ejermænd og inkluderer således relationen mellem to bestemte, byttende personer gennem hele udviklingsprocessen. Udvekslingen er derved en fixeret tosidig og, først og fremmest, symmetrisk relation mellem de udvekslende. Denne forståelse dækker imidlertid ikke det systematiske udvekslingsbegreb:

1. En udvekslingsrelation er ikke konstitueret gennem de udvekslende personer, men systematisk gennem penge. Dette betyder specielt, at de udvekslende er uden betydning for denne relation (indifferens i forhold til vareejerne), og at

2. der aldrig er tale om, at udvekslingsrelationen kun omfatter to varer, derimod altid alle prissatte varer på én gang.

Udvekslingsrelationen refererer altså for det første til totaliteten af vareverdenen og for det andet - og dette begrunder anvendelsen af begrebet »udveksling « - til denne totalitets struktur, som betragtet ud fra hver enkelt vare, som tilhører den, udgør en tosidig relation, det udfoldene udvekslingsskema. Denne tosidige relation fastlægger en social relation i hvilken ethvert medlem af (den præmonetære) vareverdenen optræder enten som den enkelte vare A på den ene side eller som en af de mange varer B på den anden. Denne relation er imidlertid på ingen måde symmetrisk. En given vares vareverdensmedlemskab er altid udtrykt gennem alle andre varer. Modsat kan den enkelte, isolerede vare aldrig udtrykke de $\varnothing$ vrige varers vareverdensmedlem- 
skab. Denne asymmetri, som Marx på den ene side behandler som forskellen værdi/ bytteværdi og på den anden side som forskellen relativ værdiform/ækvivalentform, udgør grundlaget for værdiformsanalysen (se § 5).

$\S 3$.

Den specifikke karakter af det i varerne indeholdte arbejde, som påtrykkes dette af den almene udvekslingsrelation, skal nu fastsættes. De forskellige slags varer er produceret af forskellige slags konkret arbejde, udført i produktive enheder, som er uafhængige og derfor dissocieret fra hinanden. Associeringen af disse dissocierede arbejder bliver først udrettet gennem den almene udvekslingsrelation. Udvekslingsrelationen er imidlertid en abstrakt relation mellem varer, idet produkter af kvalitativ forskellige, konkrete arbejder praktisk er sat lige med hinanden på en måde, som negligerer deres særegenhed. I kraft af udvekslingsrelationens almenhed er alle arbejdsprodukter associeret med hinanden i samme abstrakte relation, uanset arten af det konkrete arbejde. Man kan tale om en abstrakt associering af konkrete, dissocierede arbejder gennem udvekslingsrelationens almenhed.

Afsløringen af udvekslingsrelationens hemmelighed består for os ikke i simpelthen at påpege, at varerne er arbejdsprodukter. Dette er faktisk forudsat. (Marx gør implicit samme forudsætning). Den består snarere i at begribe den specifikke karakter af dette arbejde. Den kapitalistiske samfundsmæssige syntetisering af arbejdsprodukterne i udvekslingsrelationen kan ikke reduceres til noget 'simpelt begreb' om arbejde, men afslører en dobbeltkarakter ved dette, som vi i første omgang afdækker i forskellen mellem produktionens form og produktets form. At være på den ene side dissocieret, konkret arbejde, og på den anden side abstrakt associeret arbejde konstituerer den specifikke karakter af kapitalistisk formbestemt arbejde. Denne dobbeltkarakter viser sig imidlertid ikke kun i forskellen mellem produktion og produkt, men såvel i produktionen som i relationen mellem produktion og konsumtion. Førstnævnte er temaet i unders $\varnothing$ gelsen af den kapitalistiske produktionsproces som valoriseringsproces (se VRAK 2), sidstnævnte i analysen af den samfundsmæssige reproduktionsproces (se VRAK 4). I modsætning til Marx, er det vores opfattelse, at betydningen af varens karakter af at være på den ene side værdi og på den anden side genstand for konsumtion (brugsværdi) først kan begribes i forbindelse med undersøgelsen af den samfundsmæssige materielle reproduktionsproces.

$\S 4$.

Som en objektivering af abstrakt associeret arbejde er varen i kraft af den almene udvekslingsrelation konstitueret som vardi. Værdi er arbejdets specifikke samfundsmæssige form i den borgerlige epoke. Som et produkt af abstrakt associeret arbejde er varen almen, medlem af vareverdenen. Modsat er varen som produkt af dissocieret konkret arbejde saregen. 
(a) Det udviklede værdibegreb resulterer af at stille spørgsmålet: 'Hvad sker der i udvekslingsrelationen?' Dette spørgsmål skal adskilles fra dét, som stilles af ortodokse fortolkere af Marx, både marxister og ikkemarxister, og som vedrører vareudvekslingens kvantitative proportioner og deres årsager: 'I hvilket forhold udveksles de forskellige varer?' Disse to spørgsmål angiver forskellen mellem den formanalytiske fremgangsmåde og den traditionelle arbejdsværditeori, hvor sidstnævnte kan betegnes som (klassisk eller neo-)ricardiansk. Selv hvor neoricardianerne explicit afviser (den ricardianske) arbejdsværditeori (f.eks. Steedman), kan de intet få ud af Marx’s formanalyse. Skønt Marx, specielt i hans diskussion af Bailey og Ricardo (se T 2, 185ff; TüM 2, 169), kritiserer Ricardo for ikke at undersøge det værdiproducerende arbejdes form, søger han selv i Kapitalen at bibeholde begge spørgsmål og giver svar på begge. I vores rekonstruktion udelades det andet spørgsmål i første omgang, idet der koncentreres om besvarelsen af det første. Efter vores opfattelse er det den utilfredsstillende behandling af det andet spørgsmål, som udgør den væsentligste svaghed ved den marxske kapitalanalyse.

(b) Et mærkeligt paradoks! På spørgsmålet om, hvad der finder sted i den almene udvekslingsrelation, er svaret: »Samfundsmæssigt (værdi-skabende) arbejde«. Men er arbejdet ikke udført i produktionen, og er det ikke et færdigt resultat, når produkter udveksles? I samfundets nuværende form fremkommer samfundsmæssigt arbejde ikke som levende arbejde, men som dødt, størknet arbejde. Samfundet er på dette abstrakte fremstillingsniveau intet andet end vareverdenen. Hvis der imidlertid var umiddelbart samfundsmæssigt arbejde, ville der ikke være varer.

(c) Cutler et al. hævder i deres to binds værk »Marx's Capital and Capitalism Today« (London 1977 og 1978) at foretage »en radikal afvigelse fra alle tidligere fortolkninger af Marx's Kapitalen«. Her skal vi begrænse os til en undersøgelse af deres afvisning af Marx’s værditeori og pengeteorien (§ 9b), som er baseret herpå. Forfatterne indrømmer, at »der ikke er nogen simpel, sammenfattende behandling af 'værdi' eller af 'værdiloven' ... i Kapitalen« (Vol. 1, 9f), hvorfor de begrænser sig til at kritisere »en bestemt formulering af værdibegrebet og værdiloven, som kan findes i Kapitalfremstillingen« (ibid. 10). Fra begransningen af behandlingen til én værditeori, hentet ud af den tvetydige behandling af værdi i 'Kapitalen', konkluderer forfatterne: »Derfor anser vi en sammenfattende gennemgang af Marx's referencer til værdi ... for at være overflødig« (ibid.). En mærkelig logik. Hvis det indrømmes, at der hos Marx er mere end én argumentationsgang, og at der endog kan udsondres uforenelige versioner af værditeorien, da kan en kritik af den ene version, den ortodokse arbejdsværditeori, på ingen måde gøre det af med de potentielle muligheder for 
at rekonstruere Marx's værditeori. Vi kan stort set tilslutte os, at Cutler et al. har peget på et $\varnothing \mathrm{mt}$ punkt i Marx’s præsentation af værditeorien, nemlig påstanden om, at der i vareudvekslingen sker en ligesætning af arbejdskvantiteter; den såkaldte kvantitative 'værdilov'. Cutler et al. forstår værdi rent kvantitativt, dvs. (som mål/mængder af arbejdstid) som arbejdstidsstørrelser og forveksler derigennem det marx'ske værdibegreb med værdistørrelsesbegrebet. Denne forveksling fører til en fejlagtig gengivelse af Marx' værditeori, kulminerende i det absurde udsagn, at »arbejdstid er værdiens substans « (ibid. s. 35). Et andet sted taler de om »arbejde eller arbejdstid som mål for 'værdi' «(ibid. s. 20), hvorved de forveksler 'arbejde' med 'arbejdstid', og 'substans' med 'mål'. Den marxske kategori 'abstrakt alment arbejde' (abstrakt allgemeine Arbeit), som konstituerer 'værdisubstansen', diskuteres ikke. Forfatterne ser kun værditeorien $»$ som et teoretisk redskab til at analysere det samfundsmæssige produkts fordeling mellem individerne« (ibid. s. $11 \mathrm{f}$ ) og overser derved, at værdibegrebet er det teoretiske fundament for penge- og kapitalbegrebet. De ser kun, at et » værdibegreb ... er nødvendigt for mervarditeorien « (ibid. s. 16), hvor begge opfattes rent kvantitativt.

I deres diskussion af klassisk politisk økonomi og Marx's forhold hertil (ibid. s. 20ff), hævder Cutler et al., at »Ricardo udelukkende koncentrerer sig om værdistørrelsen og ser bort fra spørgsmålet om, hvorfor fordelingen af produktet antager denne form « (ibid. s. 25). Imidlertid kan Marx's analyse af værdiformen ikke fortolkes som en undersøgelse af formen for 'produktets fordeling', som det fremgår af følgende citat fra Teorier om Mervardien, ligeledes citeret af Cutler et al.:

»Men Ricardo undersøger ikke dette arbejdes form - den særlige bestemmelse af arbejdet som det, der skaber bytteværdi eller kommer til udtryk i bytteværdier eller dets karakter. Han forstår derfor ikke sammenhængen mellem dette arbejde og pengene eller, at det må komme til udtryk i penge« (T2, 186 cit. i ibid. 26).

Forfatterne må have læst denne passage meget dårligt, for de fortolker den som en kritik af Ricardo, idet han bebrejdes »ikke at forklare hvorfor udvekslingen af produkter i forhold svarende til den arbejdstid som er nødvendig til deres produktion skulle være formen for reguleringen af fordelingen af det samfundsmæssige produkt« (ibid.).

Formanalysen bliver derved (mis)forstået på følgende måde:

»I Kapitalen er værdiformen (bytteværdien) en bestemt løsning på et generelt $\varnothing$ konomisk problem, nemlig fordelingen af samfundsmæssigt arbejde i proportioner som er nødvendige for en bestemt sammensætning (?) af produktet« (ibid. s. 27; spørgsmålstegn EHKR).

Denne »misforståelse blandt Marx-fortolkere« (som Backhaus formulerer det) er særlig forvirrende, fordi denne passage eksplicit fastslår betydningen af værdiformsanalysen: »Forbindelsen mellem dette arbejde og penge «. Cutler et al. beskæftiger sig hverken med den særegne »karakter af dette arbejde« 
eller med den marxske teoris påstand om »at indvarsle en bestemt pengeteori« (Backhaus).

En yderligere misforståelse af Marx følger af forfatternes rent kvantitative fortolkning af værditeorien som en teori om fordelingen af det samfundsmæssige produkt.

Herved tillægger de Marx den Engels'ske fortolkning af »det første afsnit af første bind af Kapitalen « (Rh3, 1153; K 3, 908), som ifølge Engels også er »en historisk proces og dens forklarende genspejling i tanken « (Rh3, 1148; K 3, 905), nemlig af »forvandlingen af den simple vareproduktion til kapitalistisk vareproduktion« $(\mathrm{Rh} 3,1154 ; \mathrm{K} 3,909)$.

Det var Engels som introducerede betegnelsen »simpel vareproduktion« i marxismen, ikke Marx. Cutler et al. viderefører derved en udbredt fejlfortolkning af Marx, når de taler om »Marx’s begreb om simpel vareproduktion« (Cutler et al. vol. 1,32 ); en fejlfortolkning som endvidere blokerer indgangen til den logisk opfattede værdiformsanalyse i Bidrag til kritik.

\section{$\S 5$.}

Hvordan udtrykker en vare sig som værdi? Dette spørgsmål er det samme som: Hvorledes udtrykker konkret dissocieret arbejde sig som samfundsmæssigt arbejde, dvs. abstrakt associeret arbejde? Svaret er allerede givet i det foregående: Det udfoldede udvekslingsskema både konstituerer og udtrykker varen som værdi. Det udfoldede udvekslingsskema kan derfor betegnes som det udfoldede vardiudtryk. I dette værdiudtryk spiller varen på venstresiden en anden rolle end varerne på højresiden af udtrykket. Førstnævnte er den vare, hvis værdi bliver udtrykt og som står i relativ vardiform; vare A udtrykker sig selv som værdi i forhold til vareverdenen i varer forskellige fra den selv, i dens bytteværdier ( $\$ 2)$. Værdiudtrykket består i vare A's potentiale i henseende til at blive udvekslet mod enhver anden vare. De $\varnothing v$ vrige varer, hvori vare A’s værdi er udtrykt, står i ækvivalentform. De er vare A's ækvivalenter.

a) Kleiber og Roth finder, at det allerede på dette trin i den begrebslige udvikling, uden yderligere argumenter, er muligt at behandle penge som værdiform (se imidlertid den alternative behandling i § 6, som repræsenterer Eldreds og Hanlons opfattelse). Penge er velkendt for den umiddelbare erfaring og det faktum, at varer sælges, bringes ind i analysen som et nødvendigt skridt i udviklingen af udvekslingsrelationen (dette er vor fortolkning af $\S 2, \mathrm{~K} / \mathrm{R}$ ). Samtidig blev imidlertid den videre behandling af penge udsat i $\S 2$, og udviklingen frem til værdiformen (relativ værdiform, ækvivalentform) skred frem gennem reflektion over varernes relation til hinanden. Den anførte »seen bort fra« (blending out) pengenes formidling af vareudvekslingen er nu ikke længere nødvendig: At industrielle arbejdsprodukter må sælges for at være varer og for at have værdi, kan nu forstås gennem at 
begribe penge som almen ækvivalent (da penge formidler den i relativ værdiform stående vares udveksling med de varer, som står i ækvivalentform). Dette påvirker naturligvis kategoriernes sprog. Lige så snart penge er begrebsliggjort som værdiform, kan de to kategorier »relativ værdiform« og »ækvivalentform« ikke længere begge blive anvendt på varer (som tilfældet var på det foregående, præmonetære trin i fremstillingen); i stedet står alle varer i relativ værdiform (vareformen af værdi) overfor penge i almen ækvivalentform (pengeform af værdi). Med denne udvikling er vardiformsanalysen i snæver betydning afsluttet. Udviklingen af værdiformen og pengeformen er én og samme ting. En pengeteori i betydningen en undersøgelse af de forskellige pengetyper og deres indbyrdes relationer skal adskilles fra denne pengeformsanalyse. En pengeteori må udvikles på basis af analysen af varer og penge som værdiformer, men behøver, for at udvikles, tillige analysen af kapital. (Dette tillæg af K/R).

b) I værdiformstillægget til 1. udgaven af Kapitalen (1867) diskuterer Marx omfattende de to perspektiver fra hvilke værdiudtrykket kan anskues. Han skelner mellem forskellige værdiudtryk og anvender værdiudtryk (Wertausdruck) synonymt med værdiform (Wertform) i betegnelserne 'simpel værdiform' (Einfache Wertform), udfoldet værdiform (entfaltete Wertform). Yderligere to værdiudtryk, nemlig almen værdiform (Allgemeine Wertform) og pengeform (Geldform) bliver også introduceret. De to præmonetære værdiudtryk, det simple og det almene, opfatter vi ikke som værdiudtryk eftersom hele den $\emptyset v$ rige vareverden må stå i ækvivalentform for at kunne udtrykke en vares værdi. Herved understreger vi, at værdi alene konstitueres gennem de almene vareudvekslingsrelationer.

Indtil udgivelsen af arbejder af Rosdolsky, Backhaus, Krahl og Reichelt blev disse forskelle betragtet som pedanterier eller »rokoko-ornamenter « (Luxemburg), som blev forbeholdt avancerede marxister, hvis de da ikke ligefrem blev afvist. I denne sammenhæng er det oplysende at genlæse Marx's brev til Kugelmann, 30.11. 1967 og Engels' brev 16.7. 1867. I Althusser's forord til en fransk udgivelse af Kapitalen bind I kan man læse: »De største vanskeligheder, teoretiske og andre, som forhindrer en let tilgængelig læsning af Kapitalens første bind er uheldigvis (eller heldigvis) koncentreret i starten af bind 1, mere præcist i dens første afsnit, som omhandler »varer og penge«. Jeg vil derfor give følgende råd: Lag i første omgang hele første afsnit til side og begynd din laesning med andet afsnit $\ll$. Efter min opfattelse er det umuligt at starte med (endog at starte med) at forstå første afsnit førend du har læst og genlæst hele bind I, startende med andet afsnit « ${ }^{14}$. Sådan gik det med Marx’s fors $\emptyset \mathrm{g}$ på allerede i førsteudgavens 1 . bind at popularisere analysen af varen »mest muligt« (Rh 1, 91; K1, 11). Marx skriver videre: »Når man undtager afsnittet om værdiformen,

14. Lenin and Philosophy and other Essays London 1971, p. 81. 
vil man derfor ikke kunne beskylde denne bog for at være vanskelig at forstå « (Rh1, 92; K1, 12).

$\S 6$.

I det udfoldede værdiudtryk er en vares almenhed udtrykt gennem varerne selv, men altid gennem alle andre varer. En vares medlemskab af vareverdenen er intet andet end dens potentiale $\mathrm{i}$ henseende til at blive udvekslet mod enhver anden vare. Varens værdiværen er derfor kun udtrykt som potentiale $(\S 2)$. Det udfoldede værdiudtryk kan ikke modificeres til et faktisk udtryk for vare A's værdi, da denne består i vare A's mulighed for at blive udvekslet mod enhver anden vare. Denne almene mulighed kan ikke aktualiseres i udvekslingen med en særskilt vare. Vare A's værdiværen, dens almenhed, er alene udtrykt som aktualitet for så vidt den udveksles med en speciel vare, der har yderligere bestemmelser. Vare A's almenhed, udtrykt som potentialet i udvekslingsrelationen med vareverdenen, bliver aktualitet i udvekslingen mod denne specielle vare, penge, i skikkelse af varepenge (Warengeld). Systematisk fordobles den præmonetære vare (§2) i en prisbestemt vare og (vare)penge, hvorved den præmonetære vares særegenhed (§ 4) bliver bevaret og krystalliseret i den prisbestemte vare, og hvor dens almenhed ( $(4)$ bliver overført på penge. Penge skal i første omgang begrebsliggøres som en særegen vare, der samtidig repræsenterer vareverdenens almenhed. Som denne enhed af særegenhed og almenhed er penge enkelhed (Einzelheit). Varens almenhed bliver aktuel i dens pris, i dens salg for penge. Værdi får således sin aktuelle, bestemte væren i penge. Hvis varen viser sig at være usælgelig, da viser dens værdiværen sig at være et spøgelse. Varens relation til penge, dens pris, kan enten være potentiel (ideel pris) eller aktuel (realiseret pris). Følgelig kan værdiens pengeudtryk enten betragtes som ideel pris (salgbarhed) eller realiseret pris (salg). Dette udtryk ophæver det udfoldede værdiudtryk i den hegelske betydning: Det »sætter « varens almenhed som aktualitet og bevarer samtidig varen som potentiale i dens ideelle pris. Den mulige uoverensstemmelse mellem ideal pris og realiseret pris, som er iboende i prisformen, bliver ikke tematiseret i kapitalanalysen. Den bliver først genstand for undersøgelse i konkurrenceanalysen. Varen står i relativ værdiform (§ 5) og penge står i ækvivalentform (§ 5). I stedet for disse (præmonetære) værdiformer har vi nu værdiens vareform og værdiens pengeform.

»Varens bytteværdi er den immanente pengeegenskab; denne dens pengeegenskab løser sig fra den som penge, opnår en almen, fra alle særegne varer og deres naturlige eksistensmåde afsondret social eksistens; produktets forhold til sig selv (?) som bytteværdi bliver et forhold til nogle ved siden af det eksisterende penge....« (Gr, 60; G. 65 mod.). 
»Af modsigelsen mellem værdiens almene karakter og dens stoflige tilværelse i en bestemt vare osv. - disse almene karakterer er de samme som senere fremtræder i pengene - opstår kategorien penge« (Marx til Engels 2.4. 1858, Btk 236).

Ovenstående paragraf viser, at værdi først opnår håndgribelig eksistens $\mathrm{i}$ penge. Dette implicerer en kritik af alle præmonetære værditeorier ${ }^{15}$, dvs. af alle værditeorier (subjektive eller objektive), hvor værdi har eksistens uafhængig af penge. Dette gælder således arbejdsværditeorien - både i dens ricardianske variant og i den variant, Marx fremstiller som én argumentationskæde i Kapitalen. Ovenstående viser, at bevægelsen fra værdi til penge er en refleksionsbestemmelse (Reflexionsbestimmung) og ikke en bevægelse fra årsag til virkning, som tilfældet er i traditionelle (præmonetære) værditeorier, hvor værdi betragtes som forklarende penge-priser.

$\S 7$.

Den særegne penge-vare kan kun repræsentere varernes almenhed, hvis den adskilles fra alle andre varer gennem yderligere bestemmelser $(\S 6)$. Disse bestemmelser er for det første, at den er udelukket fra vareverdenen og for det andet, at den samtidig er umiddelbart udvekslelig med enhver særegen vare. Disse to bestemmelser konstituerer den præmonetære pengevare - som for nemheds skyld antages at være guld - som penge. Hvad mener vi mere præcist?

I) Udelukkelsen fra vareverdenen er udtrykt gennem den kendsgerning, at pengevaren ikke er en prisbestemt vare. Penge har ikke selv nogen pris; penge står altid i ækvivalentform og udtrykker kun værdien af alle (prisbestemte) varer. Som præmonetær vare stående i relativ værdiform var pengevaren imidlertid relateret til alle andre varer som dens bytteværdier. I overgangen til penge bliver pengevaren derfor systematisk udelukket fra vareverdenen.

II) Umiddelbart udvekslelig betyder, at penge-varen er direkte udvekslelig med alle prisbestemte varer. Tilsvarende er de prisbestemte varer kun udvekslelige med hinanden gennem pengenes formidling.

Penge er således i denne bestemmelse cirkulationsmiddel, formidler af vareudveksling. Køb betyder nedstigningen fra almenhed til særegenhed, mens salg er den særegne vares opstigning til værdialmenhed. Præcis fordi varepenge som enkel vare repræsenterer værdiens almenhed er den absolut vaerdi, som i sig indeholder vareverdenens almenhed og som gennem at blive gjort særegen kan forvandle sig til enhver vare.

15. Backhaus var den første til at understrege den marxske værditeori som en kritik af præmonetære værditeorier - i det mindste i Marx's intentioner. Vi har fået yderligere indsigt heri gennem diskussioner med K. Pedersen og T. Stenderup omkring deres arbejde Om problemet at etablere $\phi k o n o-$ miske begreber. Kritik af pramonetar varditeori (Stencilat, Kbh. 1982). 
Kozo Uno's Principles of Political Economy: Theory of Purely Capitalist Society (Harvester, Sussex, 1980) er en bog, som fortjener en grundigere behandling end den, vi her kan give. Vi betragter alene Uno's rekonstruktion af værditeorien og analysen af varer og penge. Omend Uno besidder stor indsigt i den marxske teori og er en af de få forfattere, som ikke afviser eller ignorerer værdiformsanalysen, må vi alligevel begrænse os til at diskutere de problematiske elementer i Uno's rekonstruktionsfors $\varnothing \mathrm{g}$. Det skulle næppe være nødvendigt at gøre opmærksom på, at afvigelser fra den marxske teori ikke i sig selv kan være grundlag for kritik. Det afgørende kritikpunkt er Uno's forslag om at udvikle et værdibegreb uafhængig af dets substans, hvor sidstnævnte først artikuleres i hans fremstilling i undersøgelsen af den kapitalistiske produktionsproces.

Værdi, som bestemt i Uno's 11. paragraf i begyndelsen af analysen af varer, »refererer til dens (varens) kvalitet af ensartethed i forhold til andre varer « (Uno, 5). Han refererer således til varens almene karakter som vareverdensmedlem. Varens værdi »kan kun blive synlig for så vidt den bliver middel til at opnå« (ibid. 8) en anden vare. I stedet for den marxske forbindelse mellem værdi og arbejde introducerer Uno et nyt element i værditeorien, nemlig varebesidderens subjektivitet: »Ejeren af en vare betragter dens værdi som den aktive handelsagent, som indbringer ham andre $\emptyset$ nskede varer« (ibid. 5). Tilsvarende er varens bytteværdi bestemt som »et ensidigt udtryk for varens værdi for dens ejer, udtrykt i brugsværdien af en anden vare, som han ønsker« (ibid. 5f). På denne måde konstruerer Uno en subjektiv værditeori, baseret på ejernes »subjektive vurderinger« (ibid. 6). Analogt til Marx udvikler Uno det simple, det udfoldede og det almene værdiudtryk samt værdiens pengeudtryk, men med den afvigelse, at disse værdiudtryk nu er udtryk for varebesiddernes subjektivitet og ikke udtryk for arbejdet, objektiveret i varerne som samfundsmæssigt arbejde. Hans diskussion af penge følger på lignende måde Marx’s teori i bind I, kap. 3. I overgangen fra simpel cirkulation til kapital begynder argumentationen at halte. Merværdibegrebet (p) bliver først defineret formelt som mer-penge, resulterende fra en cirkulation af formen $\mathrm{P}-\mathrm{V}-\mathrm{P}^{1}=\mathrm{P}+\mathrm{p}$ (ibid. 14). Herefter søger Uno i paragraf 24 at argumentere for, at hverken købmandskapital eller lånekapital $\left(\mathrm{P}-\mathrm{P}^{1}\right)$ besidder »en real kraft til at skabe en voksende værdi« (ibid. 15). Men da vardisubstansbegrebet ikke er bestemt på dette trin i analysen, kan det ikke godtgøres, hvorfor sådanne kapitalformer, som dog er i overensstemmelse med den af Uno givne, formelle definition på merværdi, ikke skaber merværdi. Konklusionen, at »kun kapital i form af industriel kapital« kan »frembringe merværdi« (ibid. 15), er derfor uargumenteret. Hvorfor skulle Uno's værditeori indebære at alene produktionen af varer er i stand til at forøge værdien? 
Både arbejdet og produktionsprocessen bliver hos Uno, i modsætning til Marx, behandlet som transhistoriske kategorier (parag. 30, 31). Hos Marx er produktionsprocessen kapitalens formbestemte valoriseringsproces. Uno introducerer arbejdets »duale karakter « i denne transhistoriske diskussion, dvs. bestemmelserne er ikke bundet til den formbestemte produktion af varer. Konkret arbejde frembringer det konkrete produkt, medens abstrakt arbejde begribes rent kvantitativt som »total arbejdstid « (ibid. 24). Konsistent med denne bestemmelse konkluderer han, at »alle samfund har denne egenskab (af dualitet, EHKR) til fælles«; »arbejdets konkrete aspekt frembringer en specifik brugsværdi og det abstrakte aspekt en værdistørrelse « (ibid. 32). Denne klare afvigelse fra Marx præsenteres nærmest som en korrektion af en misforståelse: »Det er ofte blevet misforstået, at kun det arbejde, der frembringer varer, besidder denne dualitet « (ibid.). I et brev til Engels dateret 8.1. 1868 understreger Marx udtrykkeligt sin vareanalyses specificitet: »Uden undtagelse undgik det simple faktum økonomernes opmærksomhed, at såfremt varen må besidde dobbeltkarakteren brugsværdi og bytteværdi, da må det i varerne repræsenterede arbejde også besidde dobbeltkarakter, hvorfor den blotte analyse af arbejdet sans phrase å la Smith, Ricardo etc. altid må ende op med uforklarligheder. Dette er faktisk hele hemmeligheden ved den kritiske teori« $(\mathrm{B}, 158)$.

Uno's omfortolkning af Marx på dette punkt reducerer den begrebslige skelnen mellem konkret og abstrakt arbejde til at være en transhistorisk gyldig skelnen mellem kvalitative og kvantitative aspekter af arbejdet. I betragtning af fraværet af en værdisubstansbestemmelse i starten af Uno's præsentation, må man spørge, hvorledes abstrakt arbejde, i ovenstående passage hos Uno, viser sig som bestemmende for vardistørrelsen. Hvis værdi som udgangspunkt kun manifesterede sig som varens mulighed for at blive udvekslet med andre ønskede varer, hvorfor skulle da arbejdskvantiteter nu give varen denne kraft? Faktisk indfører Uno simpelthen antagelsen at »varer bliver handlet til priser, som er proportionale med den arbejdstid, der er nødvendig for deres respektive produktion « (ibid. 25). Begrundelsen for denne forudsætning er, at under betingelser, hvor kapitalisterne ikke opnår merværdi, er denne forudsætning nødvendig, såfremt arbejderne skal kunne »få de livsmidler, som er nødvendige for arbejdskraftens reproduktion« (ibid. 26). Hvorfor skulle kapitalen ikke opnå merværdi? Selv under denne forudsætning er argumentet på ingen måde overbevisende. Denne »værdilov« (ibid.) udgør herefter den basis, på hvilken »arbejdets værdiskabelse« (ibid. 27) kan deduceres. Vi kommer således til slut tilbage til en påstand om værditeorien som en lov for udvekslingsproportionaliteter målt $i$ arbejdsindhold. Den oprindelige bestemmelse af værdibegrebet i tilknytning til varebesiddernes subjektivitet er blevet opgivet undervejs. Vi har således en subjektiv og en objektiv værditeori uden indre begrebslig forbindelse. Skønt Uno udvikler » værdiloven« $\mathrm{i}$ forbindelse med analysen af produktionsprocessen, kan der rettes 
samme indvendinger mod den, som der kan rettes mod Marx's fejlagtige deduktion af arbejdsværditeorien i Kapitalens første kapitel. Alt i alt introducerer Uno's rekonstruktion af Marx, i det mindste hvad angår værdi- og pengeteorien, flere nye antinomier end den løser. Ydermere negligeres det kritiske aspekt ved værdibegrebet, funderingen af samfundsmæssiggørelsen af dissocierede arbejder gennem vareformen, til fordel for et formuafhængigt, transhistorisk begreb om abstrakt arbejde.

\section{$\S 8$.}

I værdiens prisudtryk får varerne et ensartet udtryk som gør dem indbyrdes sammenlignelige. Deres eneste mulige forskelligheder er, i denne henseende, af kvantitativ art. Og forskelle i prisstørrelser modsvarer forskellige pengestørrelser. I ligegyldigt hvilke enheder guldpenge er standardiseret og målt, kan disse enheder reduceres til vægt i guld. Det første (kvantitative) mål for vardi udvikles således systematisk med begrebet om varepenge; alle varer får deres vaerdistфrrelse i værdiens prisudtryk. (Guld-)penge er materialet som måler den mængde af abstrakt associeret arbejde, som konstituerer værdisubstansen. Alle videre afledte pengetyper skal forstås i deres begrebslige forhold til dette varepenge mål for værdi (jvf. § 9a).

Selvom Marx udvikler guldpenge som mål for værdi har han et andet værdimål i arbejdstiden. Ifølge Marx måles værdistørrelsen i den samfundsmæssigt nødvendige arbejdstid, der er indeholdt i en vare, selvom denne værdistørrelse kun kommer til udtryk i prisen. I sin kritik af John Grays forslag om pengereform gennem et system af arbejdspenge, spørger Marx berettiget: »Da arbejdstiden er det iboende mål for værdi, hvorfor så have et andet, udvendigt mål ved siden af det? (Btk, 81; Z 67).

Svaret gives ved hjælp af sondringen mellem »dissocierede uafhængige privatarbejder, som gennem deres afhcendelse i privatudvekslingens proces skal gøre sig gældende som generelt samfundsmæssigt arbejde, dvs. at arbejdet på grundlag af vareproduktion først bliver samfundsmæssigt arbejde gennem den alsidige afhondelse af de individuelle arbejder«. (Ibid. vor fremhævelse). Arbejde bliver således først samfundsmæssigt gennem afhændelse, dvs. i prisen, og det er værdien, som udtrykker varens samfundsmæssige, almene karakter. De »dissocierede uafhængige privatarbejder « kan ikke uden videre anses for værdiskabende. Hvorledes kan så arbejdstid, det tilsyneladende indlysende mål for de dissocierede privatarbejder, være det gyldige mål for vardi? Her hjælper ikke dét argument, at arbejde, i en særlig bestemmelse, konstituerer værdisubstansen, og at værdimålet således også må have noget umiddelbart at gøre med arbejde. Hverken i Kapitalen (se Kapitalen 1, s. 132, K I, s. 53) eller i Bidrag til kritik fremfører Marx tilstrækkelige argumenter. I Bidrag til kritik bliver spørgsmålet i det mindste noget problematiseret, mens fremstillingen i Kapitalen skrider frem, som om værdistørrelsesbegrebet var indlysende. (Se RVFA pp. 35ff). Lad os se på argumentationen i Bidrag til kritik. 
»Som bytteværdier af forskellig størrelse (» 1 unse guld, $1 / 2$ ton jern, 3 skæpper hvede og 5 alen silke«) udgør de meget eller lidt, større eller mindre kvanta af dette simple, ensartede abstrakt almene arbejde, som udgør bytteværdiens substans $^{16}$. Spørgsmålet er, hvordan disse kvanta skal måles. Eller spørgsmålet er snarere, hvad der er dette arbejdes egen kvantitative tilværelse (Dasein), idet størrelsesforskelle mellem varerne som bytteværdier kun er størrelsesforskelle mellem det (private eller samfundsmæssige? EHKR) arbejde, der er materialiseret i dem. Ligesom bevægelsens kvantitative tilværelse er tiden, således er arbejdets kvantitative tilværelse arbejdstiden « (Btk 22; Z 17).

Denne argumentationsgang svarer til at sige, at eftersom »bevægelsens kvantitative tilværelse er tiden«, må værdiskabende arbejde måles i tid. Dette argument for tiden som mål for værdi er temmeligt generelt, og kunne anvendes for en hvilken som helst »bevægelse«. Med værdistørrelsen har vi imidlertid at gøre med en form-bestemt samfundsmaessig kvantitativ bestemmelse, eller mere præcist, med den kvantitative bestemmelse af arbejde som abstrakt samfundsmæssigt. Derfor kan vi ikke godtage at betragte arbejdstid som mål for arbejde, hvad angår dets bestemmelse som værdiskabende. At hævde dette fører til to forskellige mål for værdi, som er uden indre sammenhæng. Marx udvikler selv penge som målet for det vareproducerende arbejde i dets kapitalistiske form. I kapitlerne om penge i både Kapitalen og Bidrag til kritik er den første bestemmelse af penge for ham »målet for værdier«. Eftersom arbejdstid i vores rekonstruktion er ugyldigt som mål for værdi, er der $i$ begyndelsen af argumentationen intet grundlag overhovedet for bestemmelser af varens kvantitative relationer eller deres priser, som ligger udenfor bytterelationerne. I begyndelsen må de givne prisforhold betragtes som værdiudtryk. På et senere trin i analysen, i forbindelse med undersøgelsen af kapitalistisk produktion (se VRAK 2), vil varepriserne blive opløst i komponenter: Gammel værdi (»old value«), lønninger og merværdi, for bl.a. at diskutere prisernes indvirkning på merværdiproduktionen.

$\S 9$.

Vare-penge har nu tre væsentlige bestemmelser:

I Cirkulationsmiddel ( $(7)$.

II Værdimål ( $(8)$; materialet i hvilket varernes værdi opnår en kvantitativ eksistensform.

III Absolut værdi ( $(7)$; som individuel, materiel repræsentation af vareverdenens værdi-almenhed, »den almene rigdom som individuel « (Z, 103; Btk, 124 mod.) I denne sidste bestemmelse er penge ikke længere bundet til at være værdiform for industrielle varer, men kan tillige omfatte størrelser som ikke er værdier. Denne bestemmelse muliggør således begrebsliggørelsen af lønnen (og siden også andre værdifor-

16. Bemærk, at Marx i Bidrag til kritik endnu ikke havde udviklet den begrebslige forskel mellem værdi og bytteværdi. 
mer) i den efterfølgende systematiske fremstilling. Hensigten med den hidtidige fremstilling, analysen af værdiens vare- og pengeform har været at fundere en forståelse af kapitalrelationen.

a) I den hidtidige begrebslige udvikling er kun én pengetype, nemlig vareeller guldpenge, blevet udviklet. Da denne restriktion m.h.t. pengetyper ofte er blevet fremsat som kritikpunkt af den marxske teori, vil vi her - foregribende senere trin af kapital-, konkurrence- og statsanalysen - angive ${ }^{17}$ på hvilke trin i den systematiske fremstilling yderligere pengetyper kan artikuleres.

At den simple cirkulation af varer er afhængig af tilgængeligheden af en særegen industriel (præmonetær) vare, guld, der kan fungere som cirkulationsmiddel, er allerede en årsag til erstatningen af guldpenge i denne funktion med guldsymboler. Afskrivninger og omkostningerne ved at opretholde et guldomløb er yderligere årsager. Som absolut vardi er guldpenge imidlertid ikke som udgangspunkt mulige at erstatte; »Thi de er selv bytteværdiens adækvate virkelighed, og de er dette i deres metalliske eksistens « (Gr, 806; G, 872). Heller ikke som vardimål er guldpenge erstattelige på den simple cirkulations fremstillingsniveau, omend deres materialitet i denne funktion er uden betydning. Guld tjener som værdimål derved at varer idealt repræsenterer deres priser i det.

I cirkulationsanalysen (VRAK 4) udvikles banken som en aktiv kapital. Banken er karakteriseret ved to funktioner. På den ene side er den pengehandelskapital, som udfører modtager-, betalings- og opbevaringsopgaver ikke blot for andre aktive kapitaler, men også for arbejdere, jordejere og pengekapitalister. For så vidt disse opgaver udføres for andre aktive kapitaler, udfører den en væsentlig del af den totale samfundsmæssige kapitals cirkulationsfunktioner. På den anden side formidler banken lånerelationerne mellem pengekapitalister (som her omfatter alle indskydere) og fungerende kapitalister. De guldpenge, som bliver indskudt i banken, bliver udlånt til aktive kapitalister. Banken betaler indskyderne, som kan omfatte arbejdere, jordejere, penge- og fungerende kapitalister, en bestemt rente og kræver en højere rente af den pengekapital, som udlånes. (Udlån til andre formål/ satser bliver ikke betragtet her.). Med inddragelsen af banken i fremstillingen henvises vi samtidig til to nye typer penge, skønt den begrebslige udvikling af banken sker på basis af guld-penge. På den ene side har alle indskydere en bankbog med hvilken de foretager betalinger gennem instruktioner til banken. Disse guld-penge, som kan overføres, kaldes giropenge, og de opstår umiddelbart med bankens pengehandelsfunktioner. Giropenge har i sig selv intet med rentebærende kapital at gøre. For udførelsen af bankens transaktioner betaler indskyderen et gebyr.

17. Det følgende er en revideret og stærkt forkortet version af appendix til $\mathrm{DgV}$ 'Zum Ausbau der Geldstalten'. 
Giropenge er guldpenge-symbolets første konkrete form. På den anden side skaber banken sine egne guldsymboler. Dette sker gennem bankens udstedelse af sedler (nu forældet) eller simpelthen gennem skabelsen af en positiv saldo på girokonti. Eftersom et bestemt minimum af cirkulations- og betalingsmidler ${ }^{18}$ er nødvendigt for varecirkulation og revenuebetalinger, forbliver en bestemt mængde guldsymboler, som er skabt af banken (sedler og checks repræsenterende girokontisaldi), bestandigt i cirkulationen og en gulddækning er kun nødvendig for den resterende del. Bankerne agerer initierende for kreditsystemet, idet de giver kredit til kunder i form af giropenge eller sedler. Lige så snart pengesedler og giropenge bliver det almindelige cirkulations- og betalingsmiddel, må bankerne med mellemrum afvikle deres mellemværender med guldpenge. Eftersom pengesedler og giropenge er konvertible kan de begribes som en type kreditpenge i den betydning, at de kun vil blive accepteret så længe som der ikke næres tvivl om, at guld faktisk kan fås for dem. På dette fremstillingsniveau er guldpenge ene om at varetage funktionerne som værdimål og absolut værdi.

De fungerende kapitaler har endvidere muligheden af at skabe kreditpenge i form af veksler, hvilket muliggør en vis uafhængighed af banksystemet. Med sådanne kan kapitalisten købe varer og betale på et senere tidspunkt. Modtageren af vekslen får lovning om betaling på forfaldsdagen, hvor betaling må ske i form af sedler eller giropenge. Da vekslen er en egentlig kreditpenge-type, som opstår på basis af en kommerciel kredittransaktion, betaler udstederen af vekslen rente i tillæg til den normale kontantpris for de købte varer. I perioden frem til forfaldsdagen kan vekslen endvidere cirkulere som cirkulationsmiddel i varehandelen, som er den eneste pengefunktion, vekslen kan have. Giropenge og sedler vedbliver at være betalingsmidler (vedr. forskellen mellem cirkulations- og betalingsmiddel - se $\S 11$ i VRAK 2), og guldpenge vedbliver at være værdimål og absolut værdi. En veksel kan blive diskonteret af en bank således, at indehaveren af vekslen opnår »hårdere « betalingsmidler. Ved at diskontere bliver banken kreditor i forhold til den oprindelige udsteder af vekslen og modtager derfor en del af renterne på vekslen, kalkuleret i forhold til den resterende løbetid. I stedet for at udstede en veksel, som efterfølgende diskonteres af en bank, kan en debitor modtage kredit direkte fra banken i form af overtrcek. Overtrækket tillader indskyderen at disponere over giropenge udover det i banken indskudte beløb. I denne bestemmelse som 'overtrækkreditpenge' må indskyderen betale rente til banken.

På fremstillingsniveauet for staten $^{19}$ kan begrebet om statsmagten anvendes til at udvikle begrebet om pengesymboler. Med udviklingen af 'karaktermasker' til subjekter i konkurrenceanalysen ${ }^{20}$ opstår problemet vedr. garantien for

18. Pengenes funktion som betalingsmiddel udvikles først med lønarbejds-relationen (VRAK 2) og udstrækkes siden til lånerelationen mellem revenuekildeudlånere og låntagere (VRAK 3). Låneprisen betales først ved slutningen af låneperioden.

19. Se DgV afsnit VIII eller CCC\&S del IV.

20. Se $\mathrm{DgV}$ afsnit VII eller CCC\&S del II. 
guldsymbolernes konvertabilitet. Checks og veksler er konkurrencesubjekternes legale dokumenter, som forpligter de respektive udstedere. Sedler udstedt af banker er et tilsagn om på given foranledning at betale i guldpenge. Alle de forskellige typer af guldsymboler garanteres af staten derved at den tvinger subjekterne til at opfylde deres retslige forpligtelser, idet den kontrollerer og straffer de, der ikke kan eller vil gøre dette. Ingen guldsymboler må accepteres som betalingsmiddel. Mangfoldigheden af guldsymboler står i kontrast til den almene accept af guldpenge som basis for det monetære system. Inden for dets egne grænser kan staten udøve sin magt til at indføre en papirpengetype, nemlig statsudstedte betalingsmidler (som idag normalt er inkonvertible), der erklæres som lovlige betalingsmidler og som derfor overtager guldets definitive rolle i den nationale $\varnothing$ konomi. Statens lovlige betalingsmidler, udstedt af nationalbanken er definitive derved, at $\gg k \emptyset \mathrm{b}$ af varer og tjenester samt afviklingen af gæld kan kun blive definitivt udrettet med penge udstedt af nationalbanken ${ }^{21}$. Ved at regulere udbuddet af pengesedler har staten mulighed for at påvirke papirpengenes købekraft.

Dette bliver et middel i statens $\phi$ konomiske politik som pengepolitik (CCF\&S, $\S 85)$. Som følge af pengesedlernes status som lovlige betalingsmidler kan de ikke blive tvunget ud af cirkulation. I modsætning til guldpenge, der som guld kan anvendes som produktionsmiddel udenfor cirkulationen, kan papirpenge alene blive puget.

Inden for statens grænser udtrykker alle varer deres værdi i lovlige betalingsmidler. Dette værdiudtryk, som først kan begribes i analysen af staten er definitivt gyldigt, uafhængigt af relationen til guldvaren, som vedbliver at være tilgængelig på markedet. Derved bliver guld systematisk en prisbestemt vare i relation til statens lovlige betalingsmidler. Lovlige betalingsmidler tjener ikke blot som nationalt vardimål, men også som nationalt vardiopbevaringsmiddel. Alt nationalt, dissocieret vareproducerende arbejde bliver samfundsmæssig syntetiseret gennem lovlige betalingsmidler.

International handel og investering og relationen mellem stater bliver også behandlet $\mathrm{i}$ analysen af staten. Udenfor statens grænser fortsætter guldpenge med at fungere som verdenspenge, som samfundsmæssigg $ø$ r mangfoldigheden af dissocierede arbejdsprocesser, spredt udover verden. »Penge som alment, internationalt købe- og betalingsmiddel er ingen ny bestemmelse ved pengene. Det er snarere blot det samme i en fremtræden-universalitet (Universalität), der svarer til almenheden (Allgemeinheit) i pengenes begreb $(\mathrm{Gr}, 816 ; \mathrm{G}, 885)$.

Gulds specielle status som verdenspenge gælder stadig for verdenshandelen, selv hvor det deler denne rolle med papirpenge. Varen har nu en dobbelt eksistensmåde;

21. Oberst/Hintner Geld-Bank und Börsenwesen Stuttgart 1980, p. 7. 
på den ene side inden for de nationale grænser, på den anden side på verdensmarkedet. I den indre cirkulation er varens værdiværen fuldt udtrykt i derrs prisudtryk i den nationale valuta. På verdensmarkedet må varens nationale pris imidlertid forvandles til en guldpris, således at dens medlemskab af vareverdenen som verdenstotalitet kan komme til udtryk.

Kan guldpenge erstattes som verdenspenge? Ligesom det gælder for den indre cirkulation, kan også internationale guldsymboler anvendes som cirkulationsmidler. Sålænge de nationale valutaer, m.h.p. den internationale handel står i et fast forhold til guld, kan de betragtes som guldsymboler (slet og ret). I modsat fald kan en national valuta kun fungere som internationalt betalingsmiddel, hvis nationen har en stærk økonomi. Den som betalingsmiddel accepterede nationale valuta repræsenterer da et krav på den pågældende nations materielle varerigdom, og valutaen opnår status som hård valuta. Internationale kreditfonde (IMF) kan oprettes for at tilvejebringe kredit i form af nationale valutaer og guld, indskudt i fonden. Der opstår ikke nye pengetyper i den internationale handel, udover simple kreditrelationer og anvendelsen af nationale valutaer internationalt. Disse er fors $\emptyset \mathrm{g}$ på at få den internationale handel til at glide uden hjælp af guldpenge. De gentagne, mislykkede fors $\emptyset \mathrm{g}$ (Bancor, Unitas, the European Payment Union) på at skabe overnationale inkonvertible papirpenge, som med fuld gyldighed kunne fungere som værdimål, betalingsmiddel og værdiopbevaringsmiddel, kan i sidste ende føres tilbage til ikkeeksistensen af en verdensstat, som konkurrencen mellem nationerne ville være underlagt $^{22}$.

b) Vi vender os nu mod 2. bind af Cutler et al.'s arbejde, hvis første afsnit har overskriften »Penge og finansielle institutioner«. I overensstemmelse med deres afvisning af værditeorien kasserer forfatterne også »opfattelsen, at penge er værdimålet « (Cutler et al. Vol. 2,3), omend de overflødigt tilføjer andre argumenter som f.eks. at alene varepenge, iflg. forfatterne, kan fungere som værdimål, hvorfor en sådan funktion ikke kan være definerende for pengefunktionen generelt (ibid. 10). Der udtrykkes et behov for »en systematisk analyse af penge « (ibid. 3), som skal adskilles fra »en filosofisk eller erkendelsesteoretisk behandling « (ibid.). Disse metateoretiske termer anvendes for at udelukke visse af Marx's begreber selv førend der gås ind i indholdet i Marx's tekst, f.eks. »det tema, at penge repræsenterer f.eks. udvekslingens samfundsmæssighed « (ibid.) Det synes nytteløst at indtage en position i denne metateoretiske debat. Dette ville være et forsøg på at afgøre sagen endnu før man har indtaget kamppladsen. Af denne grund vil alene behandlingen af de substantielle begreber i Marx's fremstilling blive diskuteret her. Det udsagn, at »penge repræsenterer ...

22. O. Veit Reale Theorie des Geldes Tübringen 1966, p. 245ff og p. 272ff indeholder en oplysende diskussion om de mislykkede forsøg på at skabe overnationale penge. 
udvekslingens samfundsmæssighed « er i vores forståelse af Marx's tekst i alle tilfælde en tautologi. Værdi og penge er som værdiformer begreber om det samfundsmæssige arbejde, ikke simpelthen om »samfundsmæssigt bytte«. Forfatterne har også indvendinger mod et »begreb om det sociale som interpersonel relation og mod cirkulationsprocessen som mellemkomst for samfundsmæssiggørelsen af private producenter« (ibid. 14). Man kunne også forbedre denne formulering: Varecirkulationen samfundsmæssigg $ø$ r dissocierede arbejder, og da spørge hvorfor denne indsigt i vareproduktion må opgives. Værditeorien er intet andet end forsøget på at bringe denne indsigt på begreb.

Cutler et al. fortsætter deres »systematiske analyse af penge (Cutler et al. Vol. 2, 3) med at definere penge udfra deres funktioner, nemlig at penge tjener som »cirkulationsmiddel « (ibid. 5f). Forfatterne påstår, at »sådan definerer Marx penge under forudsætning af, at penge tager form af varepenge« (ibid.). Den her givne definition på penge kan begribes som noget helt forskelligt fra pengenes begreb. Det er Marx's hensigt i værdiformsanalysen at udvikle pengebegrebet fra varernes værdiudtryk. Først når dette begreb er udvundet - og først da - kan pengefunktionerne blive undersøgt. Cutler et al. er tilfredse med at give en »definition« på penge ud fra deres funktioner. På denne måde er det imidlertid ikke muligt at nå frem til pengedefinitioner, der går ud over en hverdagsforståelse. »Cirkulationsmiddel « er et umiddelbart forståeligt ord, som ikke kræver begrebslig udvikling. På Cutler et al.'s positivistiske manér bliver begrebslig udvikling afvist som værende en »rationalistisk form for begrebsdannelse« (ibid. Vol. 1, 108).

På s. 6, bind 2 fremhæves det, at skønt »Marx omtaler forskellige pengeformer ... analyseres de ikke systematisk «. Efter vores opfattelse er det helt berettiget at påpege, at Marx's analyse af pengetyperne er utilstrækkelig. Selvom kap. 3 i Kapitalen og kap. 2 i Bidrag til kritik diskuterer »guld-pengesymboler « er der ikke noget fors $\emptyset \mathrm{g}$ på systematisk at udvikle de forskellige pengetyper på grundlag af vare-penge. Med begrebet rentebærende kapital, som artikuleres i Kapitalens 3. bind, fokuserer Marx også på kreditpenge, nemlig på veksler i kap. 25 »Kredit og fiktiv kapital«. Den foranstående del af dette tillæg er en skitse til, hvorledes begreberne om de forskellige pengetyper (»pengeformer « for Cutler et al.) systematisk kan artikuleres på bestemte trin i den totale fremstilling, ikke blot i kapitalanalysen, men også i konkurrence- og statsanalysen. Med Cutler et al.'s afvisning af systematisk begrebslig udvikling gives afkald på at udfolde en adækvat teori om pengetyperne. Men uanset hvor meget man $\emptyset$ nsker at distancere sig fra forfatternes besynderlige antirationalistiske, erkendelsesteoretiske ikonoklasteri må man dog medgive, at de afslører et svagt punkt i den 'logisk-historiske' argumentationsmåde, når de kritiserer de Brunhoffs opfattelse af varepenges fundamentale karakter som funderet $\mathrm{i} \gg$ den egentlige eller oprindelige pengeform« (s. 9), hvor »det oprindelige forudsætningsvist tilskrives en erkendelsesteoretisk særstilling «(ibid.). 
Konfronteret med problemet om, hvorledes ikke-vare penge kan have værdi (ibid. Vol. 2. s. 10) er forfatternes eneste mulige løsning at konkludere at »Måling af værdi ikke kan betragtes som en definerende funktion ved penge « (ibid. s. 11) og »der findes ingen måde på hvilken ikke-varepenge kan tildeles værdi uden at værdibegrebet, som det er defineret i Kapitalen, undergraves« (ibid.). Vi er enige i den sidste konklusion, men kun fordi vi stiller spørgsmålstegn ved, hvorfor ikke-varepenge skal »tildeles værdi«. Med vores rekonstruerede værdibegreb tildeles papirpenge ikke værdi-karakter, selv ikke når de er andre varers værdiform. Alle typer af penge som kan konverteres til guld er kun symboler på guld, og kan derfor opfattes som repræsenterende en endelig mængde af pengevaren. Imidlertid kan denne pengevare ikke siges at have en værdistørrelse, men - som prcemonetcer vare $(\S 2)$ - kun en mangfoldighed af bytteværdier. Den eneste interessante type er ikke-konvertible papirpenge er det statsgaranterede, lovlige betalingsmiddel, som heller ikke har værdi eller værdist $\varnothing r r e l s e$, fordi det ikke er en industriel vare. Ikke desto mindre tjener det som værdimål for den (nationale) vareverden. Begrebet om »statsmagten « er nødvendigt for bestemmelsen af ophævelsen af guldpenge med statens lovlige betalingsmiddel. Cutler et al. antyder dette, når de skriver: »Den del af seddelomløbet, for hvilken der ikke er metaldækning (statsgaranterede lovlige betalingsmidler, EHKR) henviser ikke til noget ud over sig selv. Politisk og juridisk dækning er meget mere betydningsfuld for penge uden metaldækning end for varepenge« (ibid. s. 35).

Der kan ikke her gås ind på diskussion af Cutler et al.'s kapitler om »tuskhandel og monetær udveksling «, »Pengecirkulation«, og »kredit, finansielle markeder og finansielle institutioner «. Det er ikke umiddelbart indlysende, hvorfor en behandling af tuskhandel er relevant for analysen af den kapitalistiske $\varnothing$ konomi. Kredit og finansielle institutioner er emner, hvis rette plads er cirkulationsanalysen (VRAK 4). I de mellemliggende papirer vil vi behandle såvel den kapitalistiske produktionsproces (incl. jordrenten) (VRAK 2), som analysen af rente og revenueformerne (VRAK 3).

Oversat af Knud Pedersen, Agnete Raaschou-Nielsen og Thomas Stenderup.

\section{DETTE ER SIDSTE NUMMER NY ABONNEMENTSR EKKE GENTEGN DIT ABONNEMENT BLIV ABONNENT PÅ NR. 33-36}




\section{Vareanalyse}

\section{Bemerkninger om en artikkel av H.-G. Backhaus}

\section{Jørgen Sandemose}

I en artikkel om det logiske og det historiske felt i vareanalysen (Kurasje nr. 27/28) vil H.-G. Backhaus gi et bidrag til forståelse av Marx' stilling til Hegels dialektikk. ${ }^{1}$ Til tross for at artikkelen inneholder en rekke svært viktige påpekninger og en interessant drøfting, kommer den etter vår oppfatning på enkelte måter til kort. I noen henseender kommer Backhaus fram til standpunkter som er vanskelige å forsvare, fordi han ikke godt nok utvikler det dialektikk-begrepet som stammer fra Hegel. Følgen er blant annet at han ikke ser den avgjørende enhet mellom Hegels og Marx' metoder, og dette fører i sin tur til at han heller ikke kan klargjøre hvor og hvordan Marx' metode virkelig bryter med Hegels. Samtidig får han store problemer med å forklare hva han egentlig mener med »det logiske«, for han begrenser seg i stor grad til bruk av kategorier som verken Marx eller Hegel ville kalle logiske i ordets virkeligste betydning.

\section{Innledende bemerkninger om metode og filosofihistorie}

Backhaus' klareste formulering av sitt metodologiske »program « for tolkningen av Marx' vareanalyse er vel at »de begrebslige midler til denne værdi- og pengeteori, der er utarbejdet som værdiformanalyse, udgøres af læren om væsen og fremtrædelse « (Q 140).

Dette synspunktet utreder han i et eget metodologisk avsnitt (Q 134137). Det er ikke uten videre uriktig. Det dekker en viktig dimensjon i

1. Jfr. Hans-Georg Backhaus: »Om forholdet mellem det »logiske« og det »historiske« i Marx' kritik af den politiske $\varnothing$ konomi «, Kurasje $27 / 28$, s. 117. I resten av denne artikkelen tar vi de fleste referanser til andre forfatteres verker inn i paranteser i teksten. For oversiktens skyld bruker vi noen av de samme forkortelser som Kurasje-redaksjonen anvendte i redigeringen av Backhaus' artikkel. De er:

MEW = Marx/Engels: Werke, Berlin $1962 \mathrm{ff}$.

K 1 = K. Marx: Das Kapital, bd. I (- MEW bd. 23).

$\mathrm{E}=$ Første opplags versjon (1867) av varekapitlet i Das Kapital. Vi refererer til sidetallene i Marx \& Engels: Studienausgabe, Frankfurt am Main 1966.

Wf = K. Marx: »Die Wertform«. Appendiks (1867) til E. Vi refererer til sidetallene i Marx/Engels: Kleine ökonomische Schriften, Berlin 1955.

$\mathrm{Z}=\mathrm{K}$. Marx: Zur Kritik der politischen Ökonomie, 1859 (-MEW bd. 13)

For $\emptyset$ vrig bruker vi følgende forkortelser:

$\mathrm{Q}=$ Backhaus' artikkel, nevnt ovenfor.

L 2 = G.W.F. Hegel: Wissenschaft der Logik, bd. II, Frankfurt am Main 1970. 
Marx' kritikk av de $\varnothing$ konomiske kategorier generelt og av varen spesielt. Men det dekker ikke tilnærmelsesvis alle dimensjoner, og det treffer ikke det som er den overordnede angrepsvinkel i vareanalysen i Kapitalen - uansett hvilken utgave eller hvilket opplag en tenker på.

Vareanalysen er i eminent forstand en logisk analyse. Den dreier seg om dialektiske begrepsbestemmelser, om kategorier som skal bygge opp $\mathrm{Ka}$ pitalen som begrep. Kategorier som »vesen «, »framtredelse « (»Wesen«, »Erscheinung «, som det heter hos Hegel og Marx), »likhet«, »liksetting«, »virkeliggjøringsform «, »identitet«, »ikkeidentitet «, »differens « (som alle benyttes flittig i vareanalysen av Marx og Backhaus) er f.eks. ikke i streng forstand begrepsmessige hos Hegel, en tenker som i følge Backhaus har utviklet de »almene bevægelsesformer « som Marx ville føre sin analyse tilbake til (Q 117). At de åpenbart heller ikke er det i Marx’ oppfatning av dialektisk begrepsutvikling, skal vi komme tilbake til om et $\varnothing y e b l i k k$. Først er det imidlertid nødvendig å se noe nærmere på deres plass hos Hegel. Vi holder oss til hans Logikkens vitenskap, da det er hans begrep om det logiske felt som skal behandles.

Slike kategorier er i følge Hegel refleksjonsbestemmelser. De er selvfølgelig begreper, men de utvikles ikke i læren om begrepet. De er begreper om refleksjonen og om de former refleksjonen umiddelbart må forstås gjennom. Og refleksjonslæren er for Hegel et forstadium til begrepslæren, til læren om begrepet om begrepet. Denne teorien om begreps-begrepet danner så kvintessensen av hans egen filosofi, det aspekt ved den som - i følge ham selv - hever den opp over tidligere tenkning. Hans lære om tankenivåene forut for begrepsbegrepet, f.eks. refleksjonen, er derfor samtidig en framstilling av den tidligere filosofis standpunkter. Læren om refleksjonen, som utgjør den midterste av de tre bøkene i Logikkens vitenskap, er også en kritikk av den borgerlige filosofi i nytiden fra og med Böhme, Bacon og Descartes. Den viktigste eksponent for »refleksjonsfilosofien« er Kant.

Hva er karakteristisk for »refleksjonsfilosofien«? Først og fremst, mener Hegel, at den deler verden i to uten å ha midler til å lege dette bruddet igjen. Den er u-menneskelig, den stenger mennesket ute fra den ytre verden. Samtidig som dens talsmenn - som er mennesker som oss andre - lar den ytre verden bli underkastet et bestemt kausalt-mekanistisk prinsipp, lar den mennesket bli underkastet denne verden. Hegel mener at Kants filosofi aldri kommer ut av en slik motsetning, og at hans forsøk på å oppheve motsetningen ved »praktisk « filosofi egentlig bare reproduserer den.

Kant blir en typisk representant for refleksjonsfilosofien fordi han radikalt skiller menneskets erkjennelsesevne fra den ytre verden, fra det han 
kaller »Tingen i seg selv«. Denne toheten kan han umulig komme ut av, for han vil, som Hegel sier, liksom lære å svømme uten å gå i vannet. Hvilket er utlagt: Han vil ikke godta noen utsagn om den faktiske erkjennelsen før han har forsikret seg om hva erkjennelsen evner. Han vil først bestemme evnens struktur, og ut fra dette vil han bestemme hva som kan foregå når evnen brukes. Med marxistiske uttrykk kan en si at Kants filosofi er en åndelig gjenspeiling (eller bedre: foregripelse) av en social situasjon hvor de virkelige subjektene, arbeiderne, er blitt atskilt fra produksjonsmidlene, slik at de står ribbet tilbake hinsides naturens og samfunnets goder, overlatt til seg selv: De teller bare som en arbeidskraft eller en arbeidsevne, den er deres eneste eiendom (og den må de selge).

Hegel vil - uten å opphøre med å være borgerlig filosof - oppheve toheten i »refleksjonsfilosofien«, og det gjør han blant annet ved å lage et begrep om et teleologisk middel som skyves inn mellom menneske og ytre natur. I sin lære om begrepets begrep forstår han mennesket som et ledd $\mathrm{i}$ en trehet, ikke lenger i en tohet. Menneskene kan nå fram til en enhet med seg selv og alt annet ved å forbinde seg med sin omverden som med sine produksjonsmidler igjen. Hegels teori om begrepsbegrepet, fra dets spede begynnelse i domsformene (alle begrepers første »framtredelsesform «) til framstillingen av den idealistiske »absolutte idé«, er derfor en lære om at virkelighetens struktur er tredelt, uansett om den gir seg ut for å være todelt. Hvis den framstår som todelt, er det på grunn av en spesiell dynamikk innenfor det tredelte, eller rettere sagt innenfor det tre-enige.

Hegel mener at det er umulig å begripe noe så lenge en rett og slett er henvist til en tohet. Med bare to elementer finnes det ikke noen entydig metode til å bestemme elementene - verken ved hverandre eller hver for seg. Først når et tredje element dukker opp, kan to elementer undersøkes i forhold til en felles (kvalitativ eller kvantitativ) målestokk. Veien mellom dem blir entydig: Den går gjennom et bestemt Tredje.

Hegel kaller den forutgående filosofi i nytiden for refleksjonsfilosofi fordi den tohet den står for, begrenser erkjennelsen til speilinger, reflekser og skyggespill. Erkjennelsen er henvist til to elementers »refleksjon« i hverandre, altså deres gjensidige »skinning « (Scheinen), uten noe håndgripelig Tredje. Verden blir en slags skinnverden, hvor konkrete relasjoner bare viser seg som »Er-scheinungen «.

Men Hegel skal jo ikke rett og slett bare beskrive denne cartesianskkantianske verden. Han skal kritisere den, vise at den er falsk og sann samtidig, at den er et uttryk for noe tilgrunnliggende, at »skinnet« altså ikke lar seg tenke uten et »vesen«. I tanken om Vesenet innvarsles begrepet om Begrepet, Vesenets og Skinnets opphevelse i en høyere metodisk form. Hegels refleksjonslære, annen bok i Logikkens vitenskap, heter der- 
for »Læren om Vesenet«. Og den er refleksjonslogikk, for den viser det sted hvor refleksjonstenkningen logisk hører hjemme.

\section{Det enkle verdiuttryk: kategorisk og hypotetisk form}

Hvordan kan en i praksis finne skillet mellom tohet og treenighet $\mathrm{i}$ en slik dialektisk tilnærmingsmåte? La oss se hvilke svar vi kan få ut av vareanalysen og Marx' unders $\varnothing$ kelse av verdiens form. Denne analysen foregår ikke ut fra en refleksjonslogisk ramme, slik nærmest hele den dialektisk orienterte kommentarlitteraturen forestiller seg. Den foregår tvert om som en framstilling av en nødvendig dialektisk begrepssammenheng.

La oss få dette klart ved å ta utgangspunkt i den »enkle, individuelle eller tilfeldige verdiform «, som Marx eksemplifiserer med uttrykket 20 alen lerret $=1$ frakk, eller 20 alen lerret er 1 frakk verdt, dvs. med utsagnet

\section{»20 alen lerret er verdt 1 frakk.«}

For å se hva slags dom som her uttrykkes, bør vi være klar over det ofte oversette faktum at Marx skilte mellom to situasjoner i formutviklingen av det enkle verdiuttrykk. Skillet er gjort klarest i »Die Wertform« fra 1867. ${ }^{2}$ Verdiuttrykkets grunnlag er på den ene siden et likhetsforhold: »Basis for uttrykket... er i virkeligheten: lerret $=$ frakk, noe som uttrykt i ord bare betyr: varearten frakk er av lik natur, lik substans med varearten lerret, som er forskjellig fra den selv « (Wf 265).

Hva betyr disse »ord «, hva betyr det at ikke bare to »forskjellige « rett og slett, men to forskjellige »arter «, er satt like i samme »substans«? Hva betyr det at likheten dem i mellom er av substansiell natur? Uttrykt i terminologien fra begrepslæren ikke bare hos Hegel, men også i Kants Logik, betyr det at det er tale om en kategorisk enhet mellom to elementer. I utsagnet behandles disse elementer som subjekt og predikat. Vi står overfor en domsform, nærmere bestemt en kategorisk dom, som sammen med hypotetisk dom og disjunktiv dom danner den domstype Hegel kaller nødvendighetsdommer. Likheten mellom subjekt og predikat er nødvendig og substansiell, slik som f.eks. i dommen »A er B«, eller sagt med en empirisk variant,

2. Den følgende framstillingen av verdiformenes status er i alt vesentlig hentet fra undertegnedes skrift Kapitalbegrep-Begreps-begrep. To forutsetninger for den dialektiske logikk, Institutt for Filosofi, Oslo 1973. 
$\gg$ Gullet er et metall,«

Hvor gullet oppfattes som en del av mineralrikets substansielle (metalliske) natur. Sier jeg

$» 20$ alen lerret er verdt 1 frakk, «

taler jeg altså om et innhold som er enhetlig på en helt annen måte enn i dommen

$»$ Gullet er gult, «

hvor enheten er tilfeldig, fordi fargen (predikatet) ikke sier noe substansielt eller nødvendig om tingen (arten), og heller ikke i seg selv kan oppfattes som et slektsprinsipp som opprettholder flere arter i en substansiell og nødvendig enhet. I Marx' uttrykk består den substansielle enhet i verdien, betraktet som en felles substans for subjekt og predikat. Uttrykket forteller oss at lerret og frakk er like forsåvidt som de er »verdier«. Men dette betyr at deres relasjon ikke bare er et kategorisk forhold, altså ikke bare et likhetsforhold, men også et »verdiforhold «, som Marx sier: »Frakken er bare det samme som lerretet såfremt begge er verdier« (Wf 265).

La oss nå holde fast ved at det som skal analyseres er formen i de setninger, utsagn, likninger, dommer vi har for oss. ${ }^{3}$ Hvilken form, hvilken strukturell betingelse, er det Marx her stiller opp for den kategoriske doms forekomst? Svaret er at den kategoriske form betinges av den hypotetiske domsform. Likhetsforholdet mellom lerret og frakk er verdiforhold, men ikke alle likhetsforhold er av verdimessig art. Lerret og frakk kan f.eks. tilfeldigvis være like både forsåvidt som de begge vurderes ut fra tyngdefenomenet overhodet, og forsåvidt som de faktisk også veier like mye. Men det er ikke denne likheten vi er ute etter. Vi er ikke opptatt med fysikk med utgangspunkt i gravitasjons- eller relativitetsteori. I Marx' »bare ... såfremt « ligger allerede et hypotetisk forhold gjemt. På samme måte er det hypotetiske domsuttrykket, f.eks. »Hvis gull, så metall«, eller, for å ta et eksempel som av bestemte grunner er langt bedre,

3. Marx' kjente bemerkning om at det ikke er underlig at $\varnothing$ konomene ikke har analysert verdiformene, når »profesjonelle logikere før Hegel« ikke engang undersøkte forminnholdet i dommer og slutninger (E 274, note), er blitt særdeles dårlig forstått. Den innebærer at også den formen hans varelikninger presenteres $i$, må undersøkes kritisk av leseren. En slik kritisk lesing viser at verdiuttrykkene presenteres som et sett nødvendighetsdommer, noe som gir nøkkelen til forståelsen av kapitalens begrep slik Marx utvikler det i Kapitalen. Se videre Marx' bemerkninger om Wagners kritikk av Kapitalen, i MEW 19, s. 358: Han sier her at varen er et subjekt i hans framstilling, noe som sikkert betyr domssubjekt, og ikke umiddelbart et bevisst og handlende subjekt. 
noe som følger naturlig av den kategoriske dom med dens form »A er B.« Den er mao. en form som er nedlagt i den på forhånd, og som følgelig også begrenser dens rekkevidde og det felt av vitenskapelig erkjennelse den kan ha gyldighet i. I Marx' eksempel kommer dette til uttrykk i at den hypotetiske formen antyder analysens henvisthet til økonomiske gjenstander, og dens utelukkelse fra f.eks. en vitenskap som er basert på tyngdefenomener. Hegel mener den hypotetiske dom uttrykker at »A's væren (Sein) ikke er dens egen væren, men den andres væren, nemlig B's. « Eller mer presist uttrykt: »det endelige er riktignok sin egen væren, men like så mye ikke sin egen væren, men en annens væren « (L 2, 337). I den hypotetiske variant av det kategoriske verdiuttrykk er rammen gitt for hvordan begreper så som »fremtrædelse ... kan tilkendes en objektiv betydning inden for området af endelige, nemlig her $\emptyset$ konomiske »genstande« (Q 135). Vi skal nærme oss disse problemene gjennom å sitere Marx' oppsummering av betydningsinnholdet i verdiuttrykkets dobbelte forhold:

»At lerretet forholder seg til frakken som sin like, eller at frakken, $i$ sin egenskap av å vare ting av samme substans, blir satt lik lerretet, uttrykker altså at frakken gjelder som verdi i dette forholdet. Den blir satt lik lerretet, forsåvidt som også dette er verdi. Likhetsforholdet er altså verdiforhold, men verdiforholdet er først og fremst uttryk for verdien eller verdieksistensen (Wertsein) hos den varen som uttrykker sin verdi. Som bruksverdi eller varelegeme skiller lerretet seg fra frakken. Dens verdieksistens kommer derimot til syne, uttrykker seg, i et forhold, hvor en annen vareart, frakken, blir sat lik med den, eller gjelder som vesenslik med den« (Wf. 265-266).

Liksettingen av de to produktene er i sin helhet hypotetisk, for den forutsetter den usikre betingelse at de begge faktisk er, eller oppfattes som, verdier. Dette betyr at dommen, etter sin form, ikke »dømmer« om subjektets eller predikatets faktiske eksistens, men bare om deres innbyrdes relasjon såfremt de eksisterer. Hegel sier det slik: »Den hypotetiske dom inneholder bare den nødvendige relasjon, uten de relatertes umiddelbarhet $\ll(L 2,395)$. Rent tilsynelatende mister den derfor sin karakter av å være en dom i streng betydning, og har »forsåvidt mer skikkelse av en setning « (L 2, 338). Det er da også utvilsomt det enkle verdiuttrykks hypotetiske karakter som er den viktigste grunn til at så mange kommentatorer ensidig søker til Hegels refleksjonslogikk for å begrunne vareanalysen. For i denne logikken, »Læren om Vesenet «, framstår dommene ennå ikke som dommer, men i høyden som setninger, så som »satsen« $\mathrm{A}=\mathrm{A}$, det Hegel kaller identitetssetningen. 
Og »identitet « og »differens « har, som nevnt, i følge ham sitt hjemsted i refleksjonen. Så lenge ikke hele denne sammenhengen tas i betraktning, blir en stående ved formuleringer som: »Vare-penge-likningen er den $\phi k o-$ nomiske opphevelse av identitetssetningen ${ }^{4}$ - teser som er mer fengende enn helt uttømmende.

At setninger som $\mathrm{A}=\mathrm{A}$ forekommer i refleksjonslogikken, er for $\varnothing \mathrm{v}$ rig en god illustrasjon av selve den uholdbarhet som leder denne logikken over i begrepslogikk: Det er jo nemlig umulig å operere med en ren tohet; selve skillet mellom de to, refleksjonen, »skinningen «, er i seg selv noe tredje. Men dette tredje foreligger her i en urealisert form; ordet »er « eller tegnet $\gg=\ll$ er her ikke å oppfatte som kopula (som er den filosofiske betegnelse på »er« i en dom), mener Hegel. Det er bare begynnelsen av en kopula, for når man sier at » $\mathrm{A} \mathrm{er}$ «, så gjør man det med den forutanelse at noe forskjellig fra A skal utsies. Men dette forskjellige opptrer ikke (L 2, 44). Først i begrepets domsformer er differensieringen av innholdet kommet så langt at det enkeltstående (dommens subjekt) kan forenes med en allmenhet (predikat) og således framstå som en helhetlig, særegen ting. I følge Hegel uttrykker kopula, »er«, en trang til absolutt identitet mellom forskjellige elementer. Denne trang kommer til syne spesielt i nødvendighetsdommen, og dermed også i dens hypotetiske form. Men hvorfor framstår denne hypotetiske dom som om den bare var en »setning «?*

4. Hans-Georg Bacljais: »Zur Dialektik der Wertform«, i A. Schmidt (utg.): Beiträge zur marxistischen Erkenntnistheorie, Frankfurt am Main 1969, s. 142.

* For folk som er oppdratt med moderne »logisk « terminologi, kan det virke overflødig å skille mellom »dommer « og »setninger « i det hele tatt. En vil ha en tendens til å la dem alle falle inn under fellesbegrepet »setninger « eller »utsagn «. Dette har sin årsak i at borgerskapets autoriserte logikere etter Hegel har fortsatt den gamle tradisjonen med å se bort fra forminnholdet i dommene. Hver enkelt dom og hver enkelt domstype blir da oppfattet som stive og ubevegelige enheter, som kan analyseres hver for seg til evig tid. Overgangen mellom domstypene og domsformene, dvs. den dynamiske, overskridende faktor i menneskenes domfellelse, blir oversett. (Et eksempel på en slik dynamikk er overgangen mellom kategorisk og hypotetisk form, som vi nettopp har betraktet; et annet er overgangen fra disse formene til den disjunktive, som vi kommer tilbake til om et $\varnothing y e b l i k k$.) Det er som en følge av dette at »moderne « logikk ikke taler om dommer, men om »utsagn « - det Hegel ville kalle »setninger «. Hegel har det omvendte standpunkt av den »moderne teoriens. Hos ham er alle utsagn eller setninger egentlig dommer, i den forstand at de ikke kan stå på egne bein, uten å finne seg til rette i en større sammenheng. Når han sier at dét eller dét utsagn bare er en »ren setning « e.l., så mener han at det uttrykker et refleksjonslogisk standpunkt, hvor dets faktiske forbindelse med verden bevisst blir abstrahert bort.

Hegels terminologi, som vi for øvrig så konsekvent som mulig forsøker å følge i denne artikkelen, er slik at en dom kan oppfattes som (Hegel er ikke selv helt konsekvent i sin ordbruk) et uttrykk som dekker den og den konkrete domfellelse, f.eks. »Denne rosen er rød«, »Alle mennesker er dødelige«, »Rosen er en plante« eller »Den barmhjertige handling er god «. - Disse fire tilfellene er samtidig eksempler på det vi kan kalle hans domstyper eller arter av dommer, nemlig (i samme rekkefølge): Tilværensdommer (Eksistensdommer, Urteile des Daseins), Refleksjonsdommer (Urteile der Reflexion), Nødvendighetsdommer (Urteile der Notwendigkeit) og Begrepsdommer (Urteile des Begriffs). Hver av disse fire domstyper har i sin tur tre underklasser av dommer, som er det som her stort sett kalles domsformer. Den første deles i positive, negative og uendelige dommer (»Denne rosen er rød« er et noten fortsættes næste side 
Svaret ligger i at den kategoriske form ikke er preget av absolutt nødvendighet, fordi subjekt og predikat ikke uttømmer hverandre i sin forskjellighet. Rosen er riktignok en plante, men planten »er« ikke bare en rose, men også en mengde andre arter, som ikke nevnes i den konkrete dommen. Og når nødvendigheten ikke er absolutt, er den relativ og formell, og dette må framtre $i$ dommens form. Derfor får den en hypotetisk form: »Hvis $\mathrm{A}$, så $\mathrm{B}$, « eller »Hvis vare $\mathrm{A}$ (verdi), så vare $\mathrm{B}$ (verdi). «Denne formelle nødvendighet understreker dommens form og innebærer at den ikke kan bestemme fullstendig over sitt innhold. Men nødvendigheten virker desto sterkere når den først har fått begrenset sitt gyldighetsområde, på samme måte som et stempel først kan fungere skikkelig når det går langs vegger som slutter tett omkring det. I dette tilfellet framstår relasjonen mellom subjekt og predikat som noe altoverskyggende viktig. Men denne »relasjon « er intet annet enn det Tredje som ikke kommer til syne i refleksjonslogikken. Det toner fram for alvor i den hypotetiske dom, i Begrepets begynnelse.

Som både Kant og Hegel la vekt på, er den hypotetiske dom det begrepsmessige uttrykk for kausalitet: Hvis noe settes, følger noe bestemt annet med nфdvendighet. Når vi nå ser at den, i form av »verdilikning «, får en minst like sentral plass hos Marx som hos hans forgjengere i det filosofiske felt, må vi vente å få lære noe vesentlig om kausalitetens stilling i samfunnsmessig praksis. Kanskje vil vi også få erfare at vi står overfor den samfunnsmessige genese til kausalitetstenkning og kausalt preget naturvitenskapelig tenkning overhodet.

Den hypotetiske form i det enkle verdiuttrykks verdiforhold kommer håndgripelig til syne $\mathrm{i}$ den vekt som ligger på subjektet, på lerretet. At frakken bare er som verdi forsåvidt som lerretet er det samme, kommer

eksempel på en positiv dom); den andre i singulære, partikulære og universelle (»Alle mennesker er dødelige « er av den universelle klassen); den tredje i kategoriske, hypotetiske og disjunktive (hvor »Rosen er en plante « er kategorisk), og den fjerde i assertoriske, problamatiske og apodiktiske (»Den barmhjertige handling er god « er apodiktisk).

Som en følge av skillet mellom »setning « og »dom《 får verbformen »er«, som altså kalles dommens kopula, nemlig forbinderen av subjekt og predikat, betydning av å være et meningsinnhold, som varierer fra den ene domstype og domsform til den andre. (Selv om variasjonen ikke er større enn at kopula hele tiden må regnes som en enhet som streber etter identitet mellom subjekt og predikat.) Den er aldri det den gir seg ut for å være, - ikke det enkle »er« som den tilsynelatende er (og som den blir oppfattet som i »setninger «), men en konkret, sammensatt relasjon. I dommen »Gullet er et metall « består kopula altså av nфdvendighet. Den ytre formen »er « er sekundær, noe man kan se av at språk som latin og russisk, som i mange forbindelser ikke gjør bruk av former av verbet »å være«, kan få fram samme meningsinnhold med uttrykket »Gull metall«. (Et topppunkt av moderne logisk-filosofisk naivitet finner vi i Ludwig Wittgensteins verk Philosophische Untersuchungen, hvor forfatteren spør seg om russerne tenker seg kopula $i$ tillegg til et uttrykk som »Stein rød «! Som om ikke kopula nettopp er den forbindelse mellom en individuell sak (her: steinen) og allmen egenskap (her: rødhet) som gjør det mulig å tenke - for eksempel - en stein som noe rødt!) 
praktisk til uttrykk $\mathrm{i}$ at frakken bare er til stede som materielt substrat for lerretets trang til å vise verdien sin. Dette er kimen til det Marx kaller »varefetisj« og »pengefetisj« $(\mathrm{K} \mathrm{1,108)}$. Den hypotetiske form uttrykker altså ikke bare kausalitet rett og slett, men en reell kausalitet som bevirker mystiske forestillinger om sin egen forklaringskraft.

\section{Totalt verdiuttrykk: Disjunktiv form}

La oss for oversiktens skyld allerede nå formulere den domsform som i følge Kant, Hegel og andre (f.eks. Bradley) er enheten av den kategoriske og den hypotetiske form, og som opphever en del av disses ufullstendigheter. Det dreier seg om den disjunktive. Formulert empirisk kan den f.eks. lyde

»Metallet er enten gull eller sølv eller bronse eller osv. «5

men av grunner vi kommer tilbake til, eksemplifiseres den best med tre symboler, så som

»A er enten B eller $\mathrm{C} . \ll$

Hos Marx finner vi det »empiriske« eksemplet (E 232, jfr. K 1, 77)

»20 alen lerret $=1$ frakk eller $\mathrm{u}$ kaffe eller $\mathrm{x}$ jern eller

y hvete eller osv., osv.«

som formaliseres slik:

» $\mathrm{Z}$ vare $\mathrm{A}=\mathrm{u}$ vare $\mathrm{B}$ eller $\mathrm{v}$ vare $\mathrm{C}$ eller $\mathrm{w}$ vare $\mathrm{D}$ eller $\mathrm{x}$ vare $\mathrm{E}$ eller y vare F eller osv.«

Dette er den første utvikling av den enkle verdiform, og Marx kaller den »total eller utfoldet verdiform. «I Backhaus' skrift omtales den, også i tråd med Marx, som »form II «. Den beskrives langt grundigere og bedre i førsteutgaven av Kapitalen enn i annenutgaven. I sistnevnte utgave er hovedvekten lagt på at den som form er utilstrekkelig fordi rekken av mulige ekvivalenter for lerretet er uendelig og ikke definitiv. I førsteutgaven legger Marx minst like stor vekt på å beskrive den positivt og som en bestemt overskridelse av det enkle verdiuttrykk:

5. En merker seg at predikatet i eksemplet med den kategorisk-hypotetiske dom nå opptrer som subjekt. Ettersom vi her først og fremst er opptatt med dommens form, lar vi forklaringen av denne »omsnuingen« ligge. Vi kommer ganske detaljert inn på den i op.cit. 1973, s. 81-84. 
$\gg .$. denne annen form innebærer en vesentlig videreutvikling. Det ligger nemlig i den ikke bare at lerretet uttrykker sin verdi tilfeldig snart i frakker, snart i kaffe osv., men derimot at den uttrykker den såvel i frakker som i kaffe osv., enten i denne varen eller i hin eller i en tredje, osv.«(E 232)

Denne enhet-i-forskjellighet mellom prinsippene Såvel Som og Enten Eller er det klareste ytre kjennetegn på en disjunktiv dom, også for logikere som står langt fra Hegels dialektiske eller Kants »transcendentalfilosofiske« forståelse. I samme grad som denne beskrivelsen av verdiuttrykkets disjungerte form skyves bort fra scenen i Kapitalens annenutgave, må en si seg enig med Backhaus i at denne utgaven gir avkall på å framheve poenger som egentlig er uunnværlige for en vareanalyse.

Det sterkeste punkt i Backhaus' kritikk angår da også nettopp »form II «. Han peker på at »form III«, det Marx kaller den »allmenne verdiform «, blir utviklet på en helt annen måte i tillegget »Die Wertform« og i annenutgaven (Wf 281; K 1, 79) enn i førstekapitlet fra 1867. Denne »allmenne verdiform «, som i dette førstekapitlet heter »Tredje, omvendte eller resiproke annen form av den relative verdi, « kan oppstilles slik (Wf 281):

$$
\left.\begin{array}{ll}
1 \text { frakk } & = \\
10 \text { pund the } & = \\
40 \text { pund kaffe } & = \\
1 \text { quarter hvete } & = \\
2 \text { unser gull } & = \\
1 / 2 \text { tonn jern } & = \\
\mathrm{x} \text { vare A } & = \\
\text { osv. vare } & =
\end{array}\right\} 20 \text { alen lerret }
$$

Den er en følge av form II, eller ligger nedlagt i form II, eller (for å si det på enda en måte) »oppløser seg tilbakevisende (rückbezüglich) i form II « (K 1, 85), fordi den kan tolkes som en beskrivelse av situasjonen i form II sett fra de mulige ekvivalenters synsvinkel: $d e$ betrakter alle lerretet som ekvivalent.

Det er ingenting å innvende mot dette. Som Backhaus skarpsindig viser, er det imidlertid tvilsomt å gå direkte fra denne formen til pengeformen (Q 160), eller å oppfatte den nærmest som identisk med pengene, slik det skjer i annenutgavens 1. kapittel og $\mathrm{i} »$ Die Wertform « (Wf 286). I disse tekstene hevder Marx at lerretet i form III er utelukket (ausgeschlossen) fra den relative verdiform (plassen i likningenes venstreside) i kraft av en 
objektiv prosess fra de mange vareeiernes side. Denne objektive prosess »setter « lerretet som ekvivalentform. Det er mao. ikke noen tilfeldighet eller noe rent »subjektivt « at lerretet opptrer som ekvivalent i form III. Det eksisterer derfor, sier Marx, en avgjørende forskjell mellom formene II og III: I form II »utelukker« lerret-eieren hele kretsen av andre varer fra den relative verdiform, men denne utelukkelse kan være »en rent subjektiv prosess «, nemlig den prosess at »han beregner sin vares verdi i mange andre varer« (Wf 285, Q 160).

Såvidt vi forstår Backhaus, mener han at Marx illegitimt trekker inn det subjektive moment $\mathrm{i}$ analysen av form II, som først og fremst er en objektiv form som har behov for å få sine immanente karaktertrekk gransket.

Nå finnes det hos Backhaus en viss tendens til å sette subjektive momenter opp mot »immanente « og objektive som om de skulle være $a b$ solutte motsetninger (Q 132, 141), mens det jo i virkeligheten er slik at et immanent mål under visse omstendigheter godt kan være subjektivt bevisst og samtidig bli brukt som ytre mål. Og ved analysen av varen er det ikke gitt på forhånd at en »subjektiv prosess « ikke er en viktig forklaringsfaktor.

I dette tilfellet må en likevel si seg enig med Backhaus. Det blir nemlig for vanskelig å forstå hvordan en objektiv prosess (i form III) skal kunne framstå som subjektiv så snart den ses fra den motsatte synsvinkel (i form II). I så fall er form III ikke lenger nedlagt i form II, slik Marx ikke desto mindre fortsetter å hevde i såvel »Die Wertform« som i annenutgaven av Kapitalen. For å popularisere stoffet gir han avkall på å framstille ikke bare overgangen fra form til form som en dialektisk bevegelse; han gir avkall på å framstille den forståelig i det hele tatt.

\section{4. »Vareformens selvopphevelse« $(Q$ 160)}

I noen vanskelig tilgjengelige passasjer argumenterer Backhaus for at »Marx prisgiver ... den i første kapitel i førsteutgaven afgørende ledetanke, at med sin almengørelse må den anden form (form II) ophæves (aufheben) og dermed samtidig den tredie form (form III) for så vidt som denne nemlig overhovedet ikke kan være noget andet end den »reciprokke « anden form « (Q 159). La oss framstille hva Backhaus kan mene med dette, før vi går over til å fortolke det disjungerte verdiuttrykk, slik vi har møtt det i form II:

I første utgave av Kapitalens vareanalyse opererer Marx med en form IV, som framgår av en nøyere undersøkelse av form II. Form IV er på en måte et alternativt produkt av form II, ved siden av form III, og den består av en uendelig rekke disjungerte verdiuttrykk. 
»I sitt utfoldede relative verdiuttrykk (form II), som bare består av dens mange, enkle verdiuttrykk, opptrer lerretet ennå ikke som allmen ekvivalent. Snarere er det her ethvert annet varelegeme som er dets ekvivalent, som følgelig er umiddelbart byttelig med det, og som altså kan bytte plass med det« (E 239).

Forekomsten av denne umiddelbare byttelighet fører oss derfor til den fjerde form:

»20 alen lerret $=1$ frakk eller $=\mathrm{u}$ kaffe eller $=\mathrm{v}$ the eller $=\mathrm{x}$ jern osv;

1 frakk $=20$ alen lerret eller $=\mathrm{u}$ kaffe eller $=\mathrm{v}$ the eller $=\mathrm{x}$ jern osv;

$\mathrm{u}$ kaffe $=20$ alen lerret eller $=1$ frakk eller $=\mathrm{v}$ the eller $=\mathrm{x}$ jern osv;

$\mathrm{v}$ the $=$ osv. $\ll$

Marx fortsetter:

»Men tilbakevisende (rückbezogen) gir hver av disse likningene frakk, kaffe, the osv. som allmen ekvivalent; de gir altså verdiuttrykket $\mathrm{i}$ frakk, kaffe, the osv. som allmen relativ verdiform for alle andre varer. Den allmenne ekvivalentform tilkommer alltid bare en vare, i motsetning til alle andre varer; men den tilkommer enhver vare i motsetning til alle andre. Men hvis enhver vare stiller sin egen naturalform framfor alle andre varer som allmen ekvivalentform, så utelukker alle varer alle fra den allmenne ekvivalentform, og dermed (utelukker de) seg selv fra den samfunnsmessig gyldige framstilling av sine verdistørrelser « (E 239-240).

For å se hvordan dette er det samme som »vareformens selvophævelse« (Q 160), kan vi sammenlikne det med en passasje i Kapitalens annet kapittel, »Bytteprosessen «, et kapittel som forble uforandret $\mathrm{i}$ annen utgave av verket, og som mao. bygger på det opprinnelige førstekapitlet. Det heter her:

»Ser vi nærmere etter, så gjelder enhver fremmed vare som særegen ekvivalent for enhver vareeiers egen vare; hans vare gjelder altså som allmen ekvivalent for alle andre varer. Men ettersom alle vareeiere gjør det samme, er ingen vare allmen ekvivalent, og varene har derfor heller ingen allmen relativ verdiform, hvor de setter seg like som verdier og sammenlikner seg som verdistørrelser. Følgelig står de overhodet ikke overfor hverandre som varer, men bare som produkter eller bruksverdier $\ll(K 1,101)$.

At produktene ikke lenger framstår som varer, men nettopp som produkter, er »vareformens selvopphevelse «, i følge Backhaus. Han legger da også stor vekt på denne passasjen fra annet kapittel (Q 155). Passasjen 
utfyller den nettopp refererte argumentasjonen fra første kapittel, for ved å utelukke andre varer fra allmen ekvivalentform, utelukker en vare seg selv fra en allmen relativ verdiform, som bare er et annet uttrykk for den samfunnsmessig gyldige (les: allmen-gyldige) framstilling av dens verdistørrelse. Den samfunnsmessige utvikling av den allmenne ekvivalent går sammen med en tilsvarende utvikling av den relative verdiform. Er en ekvivalent virkelig allmengyldig, så er den det fordi alle andre varer så å si automatisk, uten innsigelser, inntar sine plasser i relativ verdiform og følgelig ikke lenger er umiddelbart byttelige mot hverandre, men bare mot pengene - en situasjon hvor form IV (med et betydningsfullt unntak, som vi kommer tilbake til) ikke lenger kan oppstå. Før pengene er utviklet logisk, går derimot varenes verdiuttrykk kontinuerlig »till grunne « i stadig nye uendelige rekker av disjunktive verdiuttrykk. En analyse av uttrykkenes objektive sammenheng viser altså at denne er for svakt utviklet til å kunne opprettholde seg. En kan i tråd med dette godt si at form II uttrykker en subjektiv prosess, men da må en si det samme ikke bare om form IV, men også om form III. Og det må argumenteres for at alle disse subjektive prosesser har et felles objektivt grunnlag.

Det eneste alternativ til å gå til grunne i disjunksjoner, er at den allmenne ekvivalent utvikles i pengeform, dvs. som edelmetall. Denne form kunne illustreres av at faktorene 2 unser gull og 20 alen lerret byttet plass i framstillingen av den »allmenne verdiform«, ovenfor. - »Selv om gull og sølv ikke er penger fra naturens side, er pengene av natur gull og sølv« (Z 131). Vi skal ikke her gå inn på årsakene til at den allmengyldige ekvivalent er knyttet til metalliske materialer, men snarere konsentrere oss om det terminologiske og logiske dilemma »vareformens selvopphevelse« bringer oss opp i, et dilemma som løses med pengeformen.

Dilemmaet uttrykker seg ved at vi på den ene siden utgår fra et verdiuttrykk som er framtredelsesform for varen, for så på den andre siden å ende opp i en konklusjon om at produktene ikke står i et slikt verdiuttrykk med hverandre: De står overfor hverandre bare som produkter. Motsetningen kan en forsøke å oppklare terminologisk ved å innføre kategorien »umiddelbart produktbytte «, slik Marx gjør det: »Det umiddelbare produktbytte har på den ene siden det enkle verdiuttrykks form, og har det på den andre siden allikevel ikke. Denne formen var x vare A - y vare B. Det umiddelbare produktbyttes form er: $\mathrm{x}$ bruksgjenstand $\mathrm{A}$ - y bruksgjenstand $\mathrm{B}$. Tingene A og B er her ikke varer før byttet, men blir det først gjennom byttet « (K 1, 102). Den manglende overensstemmelse mellom realitet og begrep løses gjennom handling, for handlingen er ikke absolutt bundet av tankens bestemmelser og krav til harmoni mellom seg selv og sin gjenstand. Det samme gjelder her som ved den samfunnsmessige hand- 
lingsrekke som til slutt utkrystalliserer gull og sølv som allmenne ekvivalenter: »I sin forlegenhet tenker våre vareeiere som Faust: I begynnelsen var handlingen. De har derfor handlet allerede før de har tenkt « $(\mathrm{K} 1,101)$, og setter i gang en serie produktbytter som så utvikler edelmetallene som allmen akvivalent. Men dette er en situasjon som ikke direkte angår den logiske framstilling i kapittel 1 av Kapitalens førsteutgave. Denne framstillingen forutsetter at produktene motsigelsesfritt kan kalles varer, dvs. fullt ut kan inngå i det enkle verdiuttrykks form, i motsetning til hva som er tilfellet med det umiddelbare produktbytte. Marx viser så at når varen på denne måten skal tenkes i en form (nemlig verdiuttrykkene) som er harmonisk med den selv, så går den ikke desto mindre til grunne hvis den ikke tenkes som ledd i en pengeøkonomi. Produktenes streben etter å bli varer (gjennom de umiddelbare produktbyttene) er derfor det samme som edelmetallets streben etter å bli penger. Det ene kan bare oppnås samtidig med det andre. I samme grad som vareanalysen allerede forutsetter pengene, kan en for $\varnothing$ vrig si at den er å oppfatte som en del-analyse ikke bare av pengene, men også av kapitalen, for kapitalformen er pengenes adekvate form i Marx' framstilling. Sagt med andre ord: I Kapitalen opptrer varen bare som et kapitalprodukt. ${ }^{6}$

At Marx’ opprinnelige intensjon har vært å framstille varen som en enhet med pengene kan en imidlertid få sikkerhet for allerede ved det faktum at vareanalysen er lagt fram som en serie domsformer. Med den klare tilknytning til dialektisk logisk tradisjon som Marx på samme tid påberoper seg, er det så godt som utenkelig at han skulle ha valgt denne framstillingsmåten uten å være seg bevisst at den forutsetter at et Tredje må virkeliggjøre seg overfor tohetens momenter - at altså selve framstillingsformen forutsetter ikke bare to varer eller to sider i et verdiuttrykk, men en tredje konkret enhet, nemlig pengene i metallskikkelse. Forsåvidt når Backhaus fram til korrekte konklusjoner ut fra et ufullendt bilde av Marx' metode. Fors $\varnothing$ ket på å beskrive en begrepssammenheng utelukkende med midler hentet fra refleksjonslogikk, kan være ansvarlig for at hans artikkel er spesielt lite leservennlig.

\section{Tolkning av det disjunktive verdiuttrykk}

Vi går nå over til å fortolke det disjungerte verdiuttrykk. Det kjennetegnes ved en potensielt uendelig rekke ekvivalenter, og er derfor det beste bevis på at den tohet som uttrykkes, og som uttrykkes ved noe tredje, nemlig ved likhetstegnet eller kopula'et »er verdt«, ikke forutsetter en empirisk tohet $\mathrm{i}$ betydningen »to ting «. Toheten kommer tvert om til syne ved den ene og

6. Jfr. Kapitalbegrep-Begrepsbegrep, s. 216. 
samme uendelige rekke av ting. Toheten ligger altså i og for seg verken i subjekt eller predikat, og må derfor ligge i kopula. Den er ikke en tallmessig tohet, men en deling av tanken i to motsatte former, i subjekt versus predikat, dvs. i relativ verdiform versus ekvivalentform. Kopula utelukker den vare som befinner seg i den ene form, fra den andre form. En vare må befinne seg enten i den ene form eller i den andre, uansett hvor mange andre varer den deler plass med. Likhetstegnet eller kopula spalter dem fra hverandre. Selve kopula, selve forholdet mellom subjekt og predikat, er derfor - innenfor vareanalysen (Marx) og nødvendighetsdommene (Hegel) - et disjungert forhold, et Enten Eller-forhold. Enhver dom er i seg selv en disjunksjon, og derfor kan en med full rett si at i den disjunktive dom er domsformen kommet på høyde med sitt eget begrep: Det som ligger i den på forhånd, blir nå åpent uttalt. Innholdsmessig sier den utfoldede verdiform noe om »empiriske « konkrete varer, om hva de er eller ikke er. Men det den etter sin form egentlig sier, er

»En vare er enten i relativ verdiform eller i ekvivalentform.«

Dette er så å si et »metauttrykk« om verdiuttrykket, og likhetstegn er ikke lenger påkrevd. I stedet trer en allminnelig kopula, »er«, men da i betydningen »er enten eller «. En ting er enten det ene eller det andre. Det er av slike grunner at dommen

\section{$\gg \mathrm{A}$ er enten $\mathrm{B}$ eller $\mathrm{C} \ll$}

er det adekvate uttrykk for den disjunktive dom, som er et formuttrykk som ikke kan bli skikkelig referert gjennom aldri så gode empiriske eksempler. Derimot kan man tale om at forskjellige empiriske innhold på en god eller dårlig måte reflekterer det formen består i. Dommen »En vare er enten i relativ verdiform eller i ekvivalentform « reflekteres, men bare »dårlig « og indirekte, av den kategorisk/hypotetiske form »20 alen lerret er 1 frakk verdt «, hvor subjekt og predikat former to poler. Den reflekteres derimot direkte av en annen disjunktiv dom, så som $» 20$ alen lerret $=1$ frakk eller $\mathrm{u}$ kaffe eller $=\mathrm{v}$ the osv. . Men da reflekteres den godt $i k k e$ ganske enkelt fordi begge former er disjunktive. En slik tankegang ville innebære at en hefter seg ved rent ytre likhetstrekk, og så bort fra den immante, nødvendige enhet og likhet som på forhånd tenkes nedlagt i kopula. - Den reflekteres godt fordi det sistnevnte disjunktive uttrykk etter sin form kan tenkes som en bekreftelse av det som blir utsagt i det førstnevnte uttrykket. For det Marx har vist, er jo at form III ligger nedlagt i form II. I det disjunktive verdiuttrykk ligger det altså en form som kan sies å bekrefte det førstnevnte uttrykk med en nødvendighet som tilsvarer den form for 
objektiv sammenheng mellom subjekt og predikat som i vareanalyse og nødvendighetsdommer er tenkt inn i likhetstegn og kopula. Oppfatter vi nemlig form III slik Marx oppfatter den i »Die Wertform«, altså som en pengeform, så innebærer den jo at varene en gang for alle er plassert på én bestemt side av likhetstegnet. At deres posisjon i én form er deres negasjon i den andre, framstår derfor helt klart.

Men dette er altså også bare det som er tenkbart etter formen. Vi har nettopp sett at Marx kommer til uholdbare konklusjoner ved å legge all vekt på formelle forhold framfor på den objektive forbindelsen mellom subjekt og predikat. La oss se litt nærmere på hvilke forbindelser han legger vekt på i det opprinnelige førstekapitlet, og som han skyver i bakgrunnen såvel $\mathrm{i}$ »Die Wertform《som $\mathrm{i}$ annenutgaven.

I relasjonen »enten eller « er det som nevnt til stede et »såvel som«: Lerretet uttrykker sin verdi i alle andre varer. Den framstiller hele den $\varnothing$ vrige vareverden som hva vi kan kalle en positiv totalitet overfor seg selv; forsåvidt utelukker varene i ekvivalentformen ikke hverandre, men framstår rett og slett som et totalaggregat av varer. Det er dette »såvel som« som uttrykkes i form III, hvor det ved en omsnuing kommer til uttrykk hva som ligger nedlagt i form II. Sterkere kunne det vanskelig bli understreket at Backhaus har rett når han sier at form III »overhovedet ikke kan være noget andet « enn den tilbakebøyde form II. Form III er rett og slett totalitetsaspektet ved form II, forsåvidt som form II oppfattes som et disjunktivt uttrykk.

Det blir klarere hvilken blindgate som ligger i framstillingen $\mathrm{i} \gg$ Die Wertform «: Av form II, hvor lerret-subjektet står overfor en predikatenhet av »enten eller « og »såvel som«. Dette skjer i form av form III, men analysen av denne formen blir mildt sagt inadekvat fordi vi ikke engang skal vite at det faktisk er et slikt aspekt som blir undersøkt. Resultatet er at hele begreps- og domsstrukturen i vareanalysen blir tilslørt.

Dette har enda mer negative konsekvenser sett på bakgrunn av at framstillingen i førsteutgaven var spesielt skarpsindig og bygde opp verdiuttrykkene i en perfekt progresjon: Det var all grunn til å la den første oppstillingen av et disjunktivt uttryk bli fulgt av et uttrykk som framstilte prinsippet »såvel som «i en særskilt »dom《. For dette prinsippet er det tilgrunnliggende og vesentlige bak om forestillingen om et »enten eller «. Det er det »verdi-vesen « som dukket opp i det hypotetiske verdiuttrykk. Det er det felleslige for hele predikatets sfære, for alle ledd i predikatet. Skal det framstille seg særskilt, kan det derfor bare gjøre det i et uttrykk som unnlater å sette de predikative ledd opp mot hverandre. Dette kan bare skje når de snus om til venstre side av kopula. 
Vi har nevnt at den disjunksjon, det »enten eller«, som finnes mellom predikatets ledd, for Hegel egentlig er en disjunksjon mellom på den ene siden »prinsippet« Såvel Som, på den andre »prinsippet« Enten Eller. Dommen uttrykker altså først og fremst motsetningen mellom 1) artene oppfattet som en totalitet, som summen av arter; og 2) artene oppfattet som resultater av slektens produksjon. Denne »slekt« er subjektet i dommen. Den er ikke en empirisk slekt så som Metall, Kattedyr o.l., men selve begrepet om en slekt, vår måte å konstruere slektsbegreper på. Tilsvarende er leddene i predikatet ikke empiriske arter, men er vår måte å tenke »arter« på. Hegel mener nå at artsbegreper - tatt i denne spesielle og overordnede betydning - er produkter av slektstenkningen. De er særegne tanker, produkter av den tenkning som tenker begrepet »slekt «. Forstår vi denne strukturen, så forstår vi også den form, dvs. den tenkemåte, som ligger til grunn for at vi feller empiriske disjunktive dommer så som

»Metallet er enten gull eller sølv eller bronse eller platina eller osv. i det uendelige. «

I slike dommer er det umulig å si at slekten produserer artene: Vi kan ikke i slekten finne noe spesifiserende prinsipp som avgjør hvilke arter, og hvor mange, som finnes. Predikatets ledd kan fortsettes i det uendelige.

Det er annerledes med tenkningen oppfattet som slekt, eller med det logiske; for logisk inneholder dommen bare et begrep bestemt både som »såvel som« og som »enten eller«. Andre strukturelle trekk er det umulig å finne innenfor den - rent bortsett fra oppdelingen i subjekt, predikat og kopula. - Undersøker vi den disjunktive dom etter dens form, vet vi derfor på forhånd at vi har et subjekt som har evnen til å bestemme antallet »arter« og deres natur fullstendig. Dette subjekt er i følge Hegel den felles allmenhet, den nødvendige forbindelse, som dukket opp i den hypotetiske dom. Denne allmenhet er et begrep, og dette begrep beskrives i predikatet i den disjunktive dom. Det består av totalitet $o g$ av et spesifiserende prinsipp. Totaliteten er summen av arter (»såvel som«), mens det spesifiserende prinsipp, som kommer til syne $\mathrm{i} »$ enten eller «, produserer de arter som er mulige innenfor den og den bestemte slekt, en slekt der som nevnt er blitt avgrenset og definert i den hypotetiske domsform.

Nå har vi sett at hos Marx slår form III over i form IV, noe som innebærer at den kan beskrives gjennom form IV, og omvendt. Prinsippet »såvel som« går i sin tur »til grunne« i nye rekker av »enten eller«. Ikke bare er hver enkelt rekke uten ende; antallet rekker er det også. Som Marx sier i en annen forbindelse, må dette tyde på at den relative verdiform, eller domssubjektet, er »uferdig, fordi dens (dets) framstillingsrekke aldri tar slutt « (K 1, 78). Når han kan uttale seg slik om et disjunktivt uttrykk, må det 
innebære at han i likhet med Hegel mener at det i uttrykkets form ligger nedlagt en forutskikkelse av en subjekt-type som kan bestemme sine arters antall og prinsippet for deres produksjon. I likhet med Hegel kritiserer han altså vanlige disjunktive dommer for deres uendelige predikative rekker. Men han gjør det ikke ut fra Hegels teori om tenkningen, men ut fra en analyse av arbeidsprodukter som er satt inn i en særlig sosial sammenheng. Slike produkter har både et antall og et konstruksjonsprinsipp som vi erkejnner på en helt annen måte enn empiriske ting vi finner i naturen.

På denne historisk begrensede bakgrunn kan Marx gi uttrykk for at de stadig reproduserte uendelige rekker av gjensidig utelukkende ekvivalentvarer i seg selv gjør krav på å bli erstattet av ett enhetlig uttrykk. De må forstås i sitt begrep, og alt dette blir først mulig ved pengeformen. Pengeformen skiller seg fra form III ved at den ikke går tilbake i noen uendelig rekke av uttrykk. Den går imidlertid tilbake i ett disjunktivt uttrykk, nemlig »den allmenne ekvivalents spesifikke relative verdiform « (E 240) eller »ekvivalentvarens spesifikke relative verdiform « $(\mathrm{K} 1,83)$ en verdiform som faller sammen med $»$ den utfoldede relative verdiform eller form II $\ll(\mathrm{K} 1,83)$.

Både pengeformen og den allmenne ekvivalent av formen III går altså tilbake på den disjunktive form. Men når form III tilbakebøyes i form II, er alle andre varer umiddelbart byttelige med den vare som i øyeblikket står i relativ verdiform, og følgelig blir rekken av disjunktive uttrykk potensielt uendelig. I pengeformen er det derimot bare én vare som har en slik umiddelbar byttelighet, og følgelig vil det bare stå ett disjunktivt uttrykk tilbake. Dette uttrykk, f.eks.

»2 unser gull $=1$ frakk eller 10 pund the eller 40 pund kaffe eller 1 quarter hvete eller $=$ osv., «

er verdiuttrykket for den allmenne ekvivalentvaren i dens pengeform.

Selv i det høyeste utviklingstrinn verdiuttrykkene kan nå, går framstillingen av varen og pengene tilbake i et disjunktivt uttrykk. Pengene, dvs. hele vareverdenens objektive prosess for å utelukke en felles ekvivalentvare, lar seg bare begripe og beskrive når en slik uopphevelig domsform ligger til grunn.

Et nøyere studium vil vise at et avgjørende skille mellom Hegels og Marx' metoder kommer til syne her. Hos Hegel blir den disjunktive dom og dermed alle nødvendighetsdommene på en relativt uproblematisk måte »hevet opp « $\mathrm{i}$ en »begrepsdom « og deretter forvandlet til slutninger (syllogismer). - Også hos Marx finner det sted en overgang fra »dommer « til »slutninger«, eller rettere sagt fra relative verdiuttrykk til sirkulasjon. Denne overgang er muliggjort av pengevarens utvikling, som gjør det 
unødvendig og irrelevant å sammenlikne enkeltvarer. Varene måler sin verdi i gull, og deretter sirkuleres de av gullet, i bevegelsen vare-pengervare, eller V - P - V. Om denne formen sa Marx i 1859 at den »abstrakt logisk kan reduseres til slutningsformen S - A - E, hvor det særegne danner den første ekstremen, det allmenne den forenende (zusammenschliessende) midttermen, og det enkeltstående den siste ekstremen « $(\mathrm{Z}, 76)$. Vi skal ikke her gå mer inn på slutningenes struktur i Kapitalen, ${ }^{7}$ men snarere understreke at pengevarens henvisthet til et eget disjunktivt uttrykk innebærer at hele slutningssystemet, og den kapitalistiske produksjon som formelt sett ligger i kim i det, kontinuerlig er forankret i et domsforhold som det ikke kommer fri fra. I en slutning som V - P - V - S - A - E er midttermen, kjernen i syllogismen, selv utelukkende framstillbar i et disjunktivt uttrykk. Som penger uttrykker gullet det samfunnsmessige og abstrakte arbeid i naturalform: Det abstrakt-allmene arbeid foreligger som særegent arbeid, som det arbeid som gjøres i gullutvinning. Som sådant sirkulerer det varene. Men dets særegenhet gjør at det bare kan beskrives i et forhold overfor andre varer. Gullets disjunktive verdiuttrykk er denne beskrivelse og sammenlikning mellom særegne varer.

Når Marx utviklet form IV av form II, var det for å vise »vareformens selvopphevelse«, for å si det med Backhaus. Men denne »selvopphevelse « innebærer ikke noe mer dramatisk enn at varesløret trekkes til side slik at produktene kommer til syne som det de er: Konkrete enkeltresultater av det samfunnsmessige totalarbeid. Når Marx deretter går over til å analysere det han kaller »det umiddelbare produktbytte« og verdiformene slik de da framstår, kan han følgelig få fram at de i realiteten må forstås som former som det samfunnsmessige arbeid eksisterer i. Disse former er hva vi kan kalle delinger. De isolerer produkter fra andre produkter for å kunne få i stand rent kvantitative sammenlikninger. De deler opp den organiske helhet som det samfunnsmessige arbeid egentlig alltid er. De uttrykker arbeidsdeling og privateiendom til arbeidsmidler og materialer.

\section{Vareproduksjon og begrepsdannelse}

Hegel la en etymologisk betraktning til grunn for sin fortolkning av dommene. Dom heter på tysk Urteil. Det er vanlig å forstå dette som en benevnelse på en slags logisk »elementarpartikkel«, et uspaltelig atom, en opprinnelig del (»ursprünglicher Teil«), noe som viser hvordan en sak er delt, men som selv er udelelig. Denne forståelsen står kanskje ikke i radikal motstrid til Hegels, men han legger iallfall større vekt på å forstå

7. Vi har redegjort for den i op. cit. 1973, s. 106-122 og 130-148. 
dommen som en opprinnelig deling av noe opprinnelig ett og enhetlig: »en opprinnelig deling av det opprinnelig Ene. «Det »Ene« det er tale om, er i følge Hegel Begrepet (begrepsbegrepet) selv, og her kommer det til syne en avgjørende svakhet ved hans idealistiske metode: Begrepet »som sådant « eksisterer før dommene. Begrepets elementarformer, dommene, er noe som framgår av Begrepet selv. Av dette følger det vansker som Hegel på ingen måte klarer å løse. ${ }^{8}$

For vårt formål er det nyttig å sette Hegels svakhet i forbindelse med noen radikale standpunkter han utvikler i sin analyse av den disjunktive dom. Vi har nevnt at denne dommen på mange måter er innbegrepet av domsformene, forsåvidt nemlig som de alle innebærer disjunksjon. Hegel tolker nå dette slik at Begrepet ikke lenger bare kommer til syne som subjekt, men også som ett av sine egne disjunktive ledd (L 2, 342). For disse leddene er atskilt fra hverandre ved et Enten Eller som er det samme prinsipp som det som ligger i kopula. De er med andre ord blitt bestemt i forhold til sine omgivelser på samme måte som subjektet er blitt bestemt i forhold til sine. Følgelig framstår de selv som Begrep (subjekt i dommen). I den disjunktive dom framstår altså Begrepet som noe som er produsert av det selv.

Tanken om en slik selv-produksjon er på ingen måte absurd i og for seg. Men i den grad Hegel ikke klarer å sannsynliggjøre sin egen spesielle versjon av den, hva er da mer rimelig enn å si at Begrepet, menneskenes systematiske kunnskapsproduksjon, er noe som er framgått av et disjunktivt uttryk som er noe annet enn Begrepet? Hva er rimeligere enn å tenke seg at verdiuttrykkets disjunktive form produserer en virkelighet som har

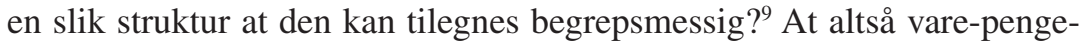
relasjonens framvekst skaper betingelsene for vitenskapelig erkjennelse $\mathrm{i}$ og av samfunn og natur? Verdiuttrykkets disjunktive form betyr jo i bunn og grunn at det er vareeierne selv som har tingliggjort sine bevisstheter, antatt vareform og gått inn i kategoriske, hypotetiske og disjunktive forhold til hverandre; de har disjungert seg selv, eller det kollektiv de selv utgjør, og dermed kan de erkjenne gjennom disjunksjon og gjennom de former (kategoriske, hypotetiske) som bygger opp disjunksjonen, samt gjennom de former disjunksjonen bygger opp.

Dommer er ikke opprinnelige delinger at et opprinnelig Begrep. De reflekterer derimot verdiuttrykk som fungerer som opprinnelige delinger av det samfunnsmessige arbeid, et arbeid som er den menneskelige erkjennelses totale form. I motsetning til hva Hegel mente, kan vi ikke få noe allment begrepp om tenkningen eller Begrepet før vi har vært i kontakt

8. Se Kapitalbegrep-Begrepsbegrep, s. 12.

9. Se Kapitalbegrep-Begrepsbegrep, s. 90. 
med empiriske arter. Men forefundne empiriske arter - av planter, metaller, dyr - gir oss ikke umiddelbart noen tilgang til det spesifiserende prinsipp vi må vite om for å erkjenne dem; og selv gir de oss vel ikke engang noen ledetråd til å erkjenne dem som arter i det hele tatt. Vår erkjennelse av dem - såvel som vår erkjennelse av vår egen tenkning overhodet - er formidlet av vår kontakt med en annen type empiriske »arter«, nemlig de vi selv har produsert. Disses historisk mest utviklede form har lenge vært vareformen. I erkjennelsen av disse »arter « og den totalitet de inngår i, har vi umiddelbar tilgang til det spesifiserende prinsipp: det ligger i det menneskelige arbeid.

En kan riktignok si at de varearter vi står overfor har et ubestemmelig antall og framstår i en tilsynelatende uendelig rekke. Men selve utviklingen av en pengevare viser at vi mestrer rekken, at vi kan produsere en oversikt der hvor den tilsynelatende må mangle: enhver ny vare lar seg underordne sitt slektsprinsipp i pengene..$^{10}$ Pengene representerer i sin tur det samfunnsmessige arbeid og gir oss kontroll over artenes prinsipp, selv om det er en kontroll som framstår tilslørt og disjungert, og ikke i en klar og umiddelbar form, slik tilfellet vil bli i det kommunistiske vare- og pengeløse samfunn.

Tolker vi form IV som et singulært, disjunktivt uttrykk og ikke som en uendelig rekke, får vi »pengevarens spesifikke relative verdiform. «Den er den versjon av form som ikke faller sammen med »vareformens selvopphevelse «, men tvert om med dens allmenne forekomst. Sammen med den form som er komplementær med den, nemlig pengeformen, f.eks.:

$$
\begin{aligned}
20 \text { alen lerret } & = \\
1 \text { frakk } & = \\
10 \text { pund the } & = \\
40 \text { pund kaffe } & = \\
1 \text { quarter hvete } & = \\
2 \text { unser gull } & = \\
1 / 2 \text { tonn jern } & = \\
\mathrm{x} \text { vare A } & = \\
\text { osv. vare } & =
\end{aligned} \text { unser gull, }
$$

innebærer den at vareverdenen er blit endegyldig disjungert i relativ verdiform på den ene siden og ekvivalentform på den andre. Den

10. Dette gjelder for den allmenne ekvivalent i det hele tatt: »I form III, som er den resiproke annen form og altså er innbefattet i den, framstår lerretet ... som slektsformen (die Gattungsform) for ekvivalenten for alle andre varer. Det er som om dyret, den individuelle inkarnasjonen av hele dyreriket, eksisterte for seg ved siden av løver, tigre, harer og alle andre virkelige dyr, som i gruppert form danner dyrerikets forskjellige slekter, arter, underarter, familier osv.« (E 234) 
objektive sammenheng $o g$ disjunksjon mellom subjekt og predikat som forutsettes i den disjunktive domsform, har dermed fått sin tilsvarighet i virkeligheten.

Da Hegel undersøkte den disjunktive form, la han vekt på at en empirisk disjunktiv dom er uten nødvendighet fordi artenes antall og prinsipp er ubestemmelig. Dette betyr at prinsippet Enten Eller egentlig er fraværende i hans betydning: Sier jeg »puma«, så mener jeg ikke »huskatt«, ikke »øve«, ikke »tiger«. Een art utelukker altså riktignok en annen, men den utelukker ikke at det kan komme flere arter inn i den rekken den står i. Den bestemmer ikke hvor mange den kan utelukkes av. Men det motsatte ligger i Hegels versjon av Enten Eller: »Enten Eller utelukker enhver ytterligere (art) og former en total sfære i seg selv« (L 2, 340). Dette er den klareste forskjell mellom ren begrepsmessig og empirisk disjunksjon.

Verdiuttrykkene, de objektive domsforhold varene og vareeierne setter seg selv i, gir oss en rasjonell middelvei mellom disse to ekstremene. Det er gjennom sin egen objektive prosess at varene er kommet inn i pengeformen. Ved sin egen aktivitet er de kommet dit hen at de 1) utelukker enhver annen vare enn gullet (eller edelmetallet) fra rollen som allmen ekvivalent, og 2) dermed utelukker at en slik annen vare kan finne plass noe annet sted enn i relativ verdiform. De utelukker altså »enhver ytterligere«, i den forstand at de på forhånd har bestemt dens form, til tross for at vareartenes rekke er uendelig. Rettere sagt er de kommet fram til pengeformen fordi varenes rekke er uendelig.

Forsåvidt skaper varene en empirisk bevegelse som likner på den Hegel mener å finne i Begrepet. Men til gjengjeld gjør de det umulig for dette Begrepet å frigjøre seg fra sine lavere former. Idet det binder Begrepet og begrepsdannelsen til konkrete, konstruerte (ikke forefundne), men allikevel empiriske ting, setter de et disjunktivt uttrykk som betingelse for den. At det må bli slik, følger av at de samfunnsmessige forhold som de konstruerte ting inngår $\mathrm{i}$, må feste seg til disse tingene selv. De må i det minste feste seg i naturalformen til en ekvivalent for dem alle, og denne ekvivalenten må uttrykke sine forhold på en disjunktiv måte. Dette er bare et annet uttrykk for at de produkter den representerer, i virkeligheten er strukturert på en måte som er ekvivalent med den disjunktive.

\section{Konklusjoner}

En av de viktigste årsakene til den manglende forståelse av Marx’ metode i Kapitalen er at verkets startpunkt har form av et hypotetisk uttrykk som lett forveksles med en refleksjonslogisk form. Dette standpunktet innebærer ikke noen nedvurdering av refleksjons-logiske faktorers be- 
tydning for vareanalysen. Tvert om, det setter slike faktorer inn i deres rette begrepsmessige sammenheng. For å ta et sentralt eksempel, nemlig undersøkelsen av varefetisjismen: Marx sier at den følger av at en vares ekvivalentfunksjon er som en »refleksjonsbestemmelse « fra en annen vares side; i det enkle verdiuttrykk er frakkens »ekvivalenteksistens (Aequivalentsein) så å si bare en lerretets refleksjonsbestemmelse« (E 231). Denne terminologien har etter vår oppfatning klar bakgrunn i Hegels teori om illusjonen slik den legges fram i refleksjonslogikken. ${ }^{11}$ Men på samme måte som Hegel har en teori om at illusjonen kan stivne ytterligere til når Begrepets sfære er nådd, er den refleksjonsbestemmelsen Marx har i tankene, avhengig av begrepets bevegelse i den hypotetiske dom: Det er fordi frakken bare er som verdi hvis lerretet er det, at dens ekvivalentstatus virker som en refleksjon fra lerretet. Verdiforholdet understreker primært »verdieksistensen hos den varen som uttrykker sin verdi « (Wf 266), som vi har sett.

Forvekslingen mellom refleksjonslogikk og begrepslogikken i domsformene har fått desto mer negative følger fordi det hypotetiske uttrykk samtidig gir oss et middel til å begripe den formen for kausalitet Marx gjør bruk av. Samtidig avgrenser den Marx' økonomiske vitenskap overfor andre teorier og vitenskaper. Oppfatningen av Kapitalen som et arnested for refleksjonslogiske kategorier vil derfor lett føre til at grunnlaget for en virkelig vitenskapsteoretisk vurdering av Marx' verk forsvinner. Den kan dessuten lede til overilte parallellføringer mellom Marx og refleksjonsfilosofer som Kant, og er uforenbar med en seriøs undersøkelse av hva Marx har ment med »det rasjonelle i den metode Hegel oppdaget« (jfr. Q 117).

En slik undersøkelse vil være godt tjent med å begynne med en ideologikritikk av Logikkens vitenskap, og et av dens fornuftigste spørgsmål kunne være: Hvorfor tolker Hegel - som den første i filosofihistorien - dommens kopula som et identitetskrav? Er det urimelig å regne med at pengeøkonomiens revolusjonerende omseggripen, det stadig mer dominerende kravet om ekvivalens mellom økonomiske størrelser, var avgjørende? - Den som vil forkaste slike problemstillinger vil også være tilbøyelig til å overse hvilken bevisst vekt Logikkens vitenskap - i klar motsetning til f.eks. Kants Kritikk av den rene fornuft - legger på begreper som lar seg overføre til en $\emptyset$ konomisk sammenheng, dvs. til en beskrivelse av menneskenes materielle produksjon. Det er ikke bare Hegels begrep om teleologi, arbeidsmidler og - materialer som er aktuelt her. Hans begrep om »midtterm « (»medius terminus«) er mer omfangsrikt enn hans middelbegrep, og gir ham anledning

11. Se Kapitalbegrep-Begrepsbegrep, s. 24, 54. 
til å konstruere et system hvor alle subjektive og objektive krefter forener seg i et sentrum, på samme måte som arbeid og natur i følge Marx subsumeres under kapitalen og forvrenges der. Det er relativt lett å parallellføre Hegels framstilling i læren om Begrepet med verdiuttrykk (dommer), sirkulasjon (syllogismer), verktøyproduksjon i manufakturen (teleologi) og kapitalistisk maskinproduksjon (absolutt idé). ${ }^{12}$ De $\varnothing$ konomiske kategoriers dominans i hans bevissthet er slående, selv om den er tilslørt og foreligger i en idealistisk form. Hvis man så i tillegg ikke lar det bli med å undersøke paralleller mellom kategorier, men også aksepterer Hegels logiske undersøkelser på deres egne premisser, kan man bare vanskelig godta at det skulle by på noe stort problem å anvende kategorier som har sitt opphav i »metafysikk«, på »endelige« $\emptyset$ konomiske gjenstander (jfr. Q 135). For som vi har sett av Hegels undersøkelse av den disjunktive form, må spørgsmålet snarere bli om ikke det såkalte økonomiske felt og kategorisystem produserer de metafysiske problemstillingene.

12. For de to sistnevnte emnene, se Kapitalbegrep-Begrepsbegrep, særlig s. $206 \mathrm{ff}$. 


\title{
Reflektioner omkring Habermas* -
}

\author{
Hans-Jфrgen Schanz
}

Også individualiteten er åbenbart et samfundsmæssigt skabt fænomen; den er et resultat af selve samfundsmæssiggørelsesprocessen og ikke udtryk for en residual behovstruktur, som unddrager sig socialisationen.

\section{Habermas i dag}

Et sted i »Zur Rekonstruktion des Historischen Materialismus« siger Habermas: »Vi har valget mellem dogmatik, trivialitet og programmatik. Jeg foretrækker programmatikken«. (pg. 129). Sammesteds siges også: »Det eklektiske skin kan ikke undgåes, så længe en kompleks og forklaringsstærk teori endnu er i statu nascendi« (pg. 129).

Habermas er ofte - som en af de mest generelle kritikker - blevet beskyldt for eklekticisme. Om ikke før, så skulle denne kritik med den nye bog »Theorie des kommunikativen Handelns « være gjort til skamme. Oftest er eklekticismedommen blevet fremført på baggrund af en identificering af eklekticisme med programmatik, apori og kompleksitetsfors $\emptyset \mathrm{g}$ via inddragelse af umiddelbart heterogene teoritraditioner. Det eklekticistiske skin er borte i den nye bog; dels på grund af omfanget: de omfattende rammer bevirker, at de programmatiske udtalelser og hurtigtopladende inspirationer fra vidt forskellige traditioner gennemargumenteres og begrundes udførligt. Aporier er ikke af denne grund udelukket, men de kan ikke længere meningsfyldt identificeres med eklekticisme. I et interview med Detlef Horster og Willem van Reijen (1979, genoptrykt i Kleine politische Schriften IIV, Ffm 1981, pg. 511-532) svarer Habermas på et spørgsmål om hans problematiske syntetiseringer, hvor altså også eklekticismedommen lurer: »Når De spørger mig, om man kan »formæle « adfærdsteorien, f.eks. den indlæringsteoretiske smågruppeforskning, således som den er blevet udviklet i USA i 50'erne, med en handlingsteoretisk baseret sociologi, parsonsk eller marxististisk, vil jeg svare: Nej. Grundbegreberne er ikke forenlige. I det ene tilfælde konceptualiserer man genstandsområdet idet man eliminerer grundbegrebet hensigt (Sinn), i det andet tilfælde tager man bevidst handling, kommunikativ handling eller værdiorienteret handling op som grundbegreb. Der er tale om klare alternativer. Det vil være omsonst at fors $\emptyset$ ge at integrere sådanne teoretiske ansatser. På den anden side tror jeg slet ikke, at pa-

* $\quad$ Artiklen er en forelæsning fra et seminar i Helsinki, januar 1983. 
radigme-mangfoldigheden er så stor. Den er snarere et kunstigt produkt af en Kuhn-inspireret videnskabsretorik. I sociologiens teorihistorie, for så vidt sociologien overhovedet har gjort krav på at være samfundsteori, fra Marx, Durkheim, Weber til Parsons osv., har et bestemt problem bestandig vist sig på grundbegrebs-niveau: Hvordan sammenknytter vi system- og handlingsparadigme hhv. system- og livsverdenparadigmet «. (pg. 527, se også »Zur Rekonstruktion«, pg. 129-131). Dette er altså Habermas selvforståelse omkring den gennemgående eklekticismebeskyldning. Måske skal vi tilføje, at denne dom også efter Thomas McCarthys Habermasmonografi: »The Critical Theory of Jürgen Habermas « (1978 USA), som altså er før den nye bog, kan reduceres til en fordom. McCarthy påpeger derimod en række aporier og problemkollisioner og manglende gennemarbejdninger, men det subsumerer han aldrig under en eklekticismebeskyldning.

Eklekticismeskinnet er endvidere bortrevet efter den nye bog på grund af den der hyppigt forekommende eksplikation af intentionen med bogen. Det programmatiske er hermed ikke ophævet, men det har i det mindste ikke længere en ren provisorisk status. En af de centrale programudtalelser lyder: »Med den foreliggende unders $\varnothing$ gelse vil jeg introducere en teori for kommunikativ handling, som afklarer det normative grundlag for en kritisk samfundsteori. Teorien for kommunikativ handling skal udgøre et alternativ til den efterhånden uholdbare historiefilosofi, som den ældre kritiske teori endnu var indfanget af; hensigten er at opstille de rammer, indenfor hvilke man på ny kan beskæftige sig med den tværfagligt anlagte forskning i den kapitalistiske moderniserings selektive mønstre« (bd. II, pg. 583).

Et spørgsmål, man uvilkårligt må stille i dag, i hvert fald når man selv kommer fra en teoritradition, der omkring 70' implicerede et brud med Habermaspositionen, er, om Habermas nu »passer bedre « end for omkring 10 år siden. Der er meget der tyder på en international renaissance, også blandt marxister for Habermas, og at han er ved at få, genvinde kunne man også sige, et større publikum. Som bekendt har der kontinuerligt eksisteret en tradition, der lod sig inspirere af Habermas, den eksisterer i Tyskland, men svandt kraftigt ind i begyndelsen af 70'erne, og den eksisterer nok med en tilsvarende grad af styrke i USA, enkelte steder i Skandinavien, men i Danmark f.eks. har det stort set været karakteristisk, at bruddet med Habermasinspirationen forløber synkront med situationen i Tyskland, dels på grund af den danske marxistiske diskussions store affinitet i slutningen af 60'erne og begyndelsen af 70'erne til den venstremarxistiske tyske tradition, hvor der jo som bekendt skete et brud omkring 70. Og dels på grund af et omsving, der ikke var totalt, men som dog var iøjnefaldende 
nok, henimod en større grad af inspiration fra en fransk, såkaldt struktural marxismeforståelse, og i legering hermed en italiensk Gransciinspireret tradition.

Stort set forekommer det mig, at den franske tradition i dens strikte marxistiske form i dag er uden større resonnans i Danmark. Det kan have mange årsager, jeg vil her pege på to, som jeg tror er centrale: for det første har denne tradition omkring Althusser helt tydeligt mistet sin dominansposition rent intellektuelt i Frankrig (det havde den måske allerede på det tidspunkt, hvor den begyndte at blive udbredt i Danmark), hvor Marxindifferentisme og uforsonlige Marxkritikker efterhånden overtog den intellektuelle scene, dels i form af en magtkritik, der opfattede sig selv som en erstatning for, og ikke et nødvendigt supplement til Marx og dels i form af en totalafvisning af Marx i stil med nyfilosofien. Althussertraditionen tørrede ud, og mangelen på nye skrifter, nye problemstillinger etc. har sikkert medvirket til, at denne tradition i Danmark også synes at være på uafvendelig retur. For det andet har denne position mistet sin indflydelse og tiltrækningskraft i kølvandet på den almene deroute for den partikommunistiske models inspirations- og tillidskraft. Det er et internationalt fænomen, men det kan fastslås som en kendsgerning. Althusserskolens udbredelse i Danmark fandt sted side om side med, og var i øvrigt også rent intellektuelt medvirkende til, en momentant fornyet tro på den partikommunistiske models nødvendighed på venstrefløjen. Hans reformulering af Marx er en reformulering på baggrund af og med retning ind $\mathrm{i}$ en partikommunistisk model. Det var dens styrke, men også historiske og teoretiske svaghed.

Bruddet med Habermasinspirationen i Tyskland fandt sted omkring 70'erne. Der kan angives mange grunde, men uafviseligt er det, at følgende to forhold var afgørende: for det første Habermas' teser om venstrefascismen og for det andet hans udtalte Marxkritik. Begge forhold blev generelt i venstrefløjen opfattet som implicerende et uforsonligt brud med venstrefløjen. Habermas opfattede det ikke således - det fremgår tydeligt af f.eks. en række interviews. Han opfattede det som et internt opgør. Venstrefløjen opfattede det som en krigserklæring. Og under alle omstændigheder blev følgen, at Habermas intellektuelt blev hjemløs, og venstrefløjen mistede interessen for hans arbejder. Dette forhold ser nu ud til at være ved at ændre sig på begge fronter.

Men altså: »passer Habermas bedre til situationen i dag?« Et sådant spørgsmål er både vanskeligt at svare på, og uomgængeligt - i det mindste for en tradition, der har rummet et gigantisk brud med Habermaspositionen. Et definitivt svar kan ikke gives, men et provisorisk er nødvendigt. 
I stiliseret forstand må man nok afvise, at Habermas' teoriansats' tilsyneladende renaissance skulle skyldes, at den »passer bedre«. En sådan opfattelse ville forudsætte, for det første at hans teoriposition restløst var forblevet passivt identisk, for det andet, at man meningsfuldt historicistisk kunne gå ud fra, at en teoriansats' sandhed udelukkende kunne måles på baggrund af dens aktuelle succes og antagne forklaringskraft. Men begge forhold er dybt problematiske: Habermas position er ikke forblevet passivt identisk siden begyndelsen af 70'erne - og dens udvikling har ikke - som sagt indledningsvist - været karakteriseret ved en eklekticistisk tilpasning til de dagsaktuelle konjunkturer. Ligeledes gælder, at tilliden til at en positions sandhedsgehalt skulle være målelig ud fra øjeblikkelig succes, ikke er mindre problematisk: både når den substantialiseres, og også når den anvendes som heuristisk princip.

Som Kritisk Teori, i selvforståelsen såvel som i den udfoldede teoripraksis, har Habermas' teoriposition(er) altid været utidssvarende i nietzeansk forstand, dvs. »imod tiden og dermed på tiden og forhåbentlig til fordel for en kommende tid «. Hertil kommer så nogle, forekommer det mig, vigtige momenter. Habermas har sjældent i blochsk forstand »haft ret til at have ret « $\mathrm{i}$ forhold til den radikaliserede venstrefløjs opfattelser, men han har til gengæld meget ofte »fået ret«. Hvortil kommer at, det besynderlige er, at Habermas tilsyneladende har beskrevet en udviklingskurve fra 70'erne og frem til i dag, der er stik modsat den kurs, man ellers generelt har set blandt venstreintellektuelle: medens han i starten blev kritiseret for elendig marxisme eller endog anti-marxisme samt en uacceptabel anti-utopisk tendens - uden at han selv kunne identificere sig med disse etiketter - så har han de senere år, og efter min mening uafviseligt i den nye bog om den kommunikative handlen, gennemspillet et forl $\varnothing b$, hvor han i højere og højere grad nærmer sig og genoptager substantielt marxistisk aktuelle problemer og vel også synspunkter. Dette finder sted samtidigt med at de gamle anklagere i højere og højere grad bliver Marxindifferente eller endog uforsonlige Marxkritikkere. Som Eberhard Knödler-Bunte skriver i sin forbemærkning til et længere interview med Habermas i » Ästetik und Kommunikation«, får man her noget at tænke over. Hvad angår det utopiske eller anti-utopiske, så har der her været en gennemgående konstans, der også er uberørt i den nye bog, hos Habermas: han tilhører ganske givet ikke den messianskeskatologiske og radikalt utopiserende tendens i den tysksprogede marxismetradition, omend han på flere punkter lader sig inspirere af den. I den henseende eksisterer der hos Habermas et substantielt moment af hegelianisme og protestantisme. Og måske er dette et punkt, som kunne være medvirkende til, at Habermas »passer bedre « i dag. 
Jeg tror, at man i det mindste kan pege på følgende tre forhold, som medvirkende til den eventuelle Habermasrenaissance:

I) Siden midten af 70'erne har der generelt i Europa (dog med politisk manifeste undtagelser i Frankrig, Grækenland og Spanien) og USA gjort sig forskellige former for konservatismer gældende $\emptyset$ konomisk, politisk og socialpolitisk samt teoretisk-intellektuelt. Man skal være forsigtig med at homogenisere, men kontrastivt i forhold til 60-'ernes enorme boom for opbrud og skred med ny-venstreorienteringen som integreret fænomen er der uafviseligt sket noget. Denne konservatismetendens har uafviseligt neddæmpet forventningsradikaliteten i det traditionelle og nye venstre, når og hvor der stadigt tænkes $\mathrm{i}$ totaliserende bestemmelser. Forholdet implicerer opkomsten af en indsigt i og en erfaring med, at en revolutionerende forandring, altså en generel emancipationstendens, må løbe $i$ et meget vidtstrakt tidsperspektiv og må tænkes under inddragelse af afviklingstendenser, i stedet for de engangsforekommende hurtige brud. En civilisationskritisk konciperet evolutionsteori bliver her nødvendig. Habermas har siden 70 insisteret på nødvendigheden af at tænke i lange evolutionskæder, lige som han meget tidligt argumenteret tog afstand fra de mest radikale her-og-nu forventninger om et på engang gennemført brud, momentet er også fremhævet i Negt/Kluges »Geschichte und Eigensinn «. Dette har været et konstansmoment i hans teoriudvikling, og er yderligere - især hvad angår det civilisationskritiske moment - blevet udbygget $\mathrm{i}$ hans sidste bog om den kommunikative handlen, der jo som andet end pynt og staffage har forskellige afsnit om »die Moderne«. Kort sagt: på dette punkt udviser Habermas udvikling både en konstans og en tiltagende uddybning og konkretisering, som kan forklare den eventuelle reaktualisering/renaissance.

II) En marxismeposition, der i dag ikke kan eller vil koncipere og videreudvikle en marxistisk kritik uden om intransparente bindinger til den traditionelle partikommunistiske model, synes ikke at have anden fremtid for sig end fortiden, senest efter den eurokommunistiske ansats' roll back synes dette at være et faktum. Dette implicerer generelt en fornyet chance for venstremarxistiske traditioner, herunder bl.a. Den kritiske Teori og mere omfattende Frankfurterskolen, efter at denne tradition momentant blev trængt i baggrunden i 70'ernes fors $\emptyset \mathrm{g}$ på venstrefl $\varnothing$ jene på at opbygge og udvikle ret så traditionelle partimodeller. Habermas tilhører og arver dette moment $\mathrm{i}$ den venstremarxistiske tradition fra den Kritiske Teori. Og i den henseende er hans Marxkritik sikkert marxistisk mere aktuel end den traditionelle partikommunistisk bundne Marxrepetion. 
III) Jeg vil endelig pege på et tredie forhold, som især ytrer sig teoretiskintellektuelt, men som dog som sådan helt klart er signatur for et centralt civilisationsmæssigt forhold, og som kan have betydning for en eventuel Habermasrenaissance. Nemlig hans brede og alt andet en letkøbte eller letsælgelige insistering på rationalitetsproblemet i omfattende betydning. Rationalitetsproblemet i omfattende betydning er hos Habermas ikke noget nyt problem - det har været selve grundproblemet siden han påbegyndte forsøget på at opspore Den kritiske Teoris normative grundlag systematisk. I et interview med Gad Freudenthal, Jerusalem 1977, angiver han følgende tre mangler ved den gamle Kritiske Teori: For det første: »Den kritiske teori har ikke taget de teoretiske ansatser, som er udviklet indenfor samfundsvidenskaberne og den analytiske filosofi, alvorligt; den har ikke, som det egentlig var dens hensigt, systematisk knyttet an til disse. Derfor har den for det andet med sin kritik af den instrumentelle fornuft fastholdt et abstrakt niveau, uden at kunne bidrage stort til en empirisk indholdsfyldt analyse af den overkomplekse samfundsmæssige realitet. Endelig har den ikke utvetydigt aflagt regnskab for sit normative grundlag, sin egen status. Adorno har benægtet muligheden af systematisk at begrunde et fornuftsbegreb, hvilket han imidlertid bestandig implicit har givet sig i kast med. Denne apori er i øvrigt for mig en grund til at udarbejde en teori for kommunikativ handling.« (Kleine politische Schriften I-IV, Ffm 1981, pg. 483-484). I forhold hertil, altså den systematiske begrundelse af et fornuftsbegreb, eller udarbejdelsen af en teori for den kommunikative handlen, er det omfattende rationalitetsbegreb indlysende centralt.

Men det er det også på to andre felter, som knytter sig til fornuftsbegrebet, nemlig i forbindelse med hans civilisationsteoretiske evolutionsteori og hans forsøg på at fastholde en totaliserende samtidsanalyse: evolutionsteori bliver blind, hvis ikke den reflekterer rationalitetsproblemet og den totaliserende samtidsanalyse bliver både tom og måske snarere umulig, hvis den ikke også forholder sig til rationalitetsbegrebet. Habermas' rationalitetsdiskussion er altså ikke alene et indre teoretisk arvmæssigt anliggende: det drejer sig således ikke alene om at udbygge hullerne i den gamle Kritiske Teori, nej, det drejer sig måske først og fremmest om at oparbejde mulighedsbetingelserne for en samtidsanalyse, en samtidsdiagnose i totaliserende forstand. Og i dette perspektiv er rationalitetsproblemet yderligere accentueret i dag. Problemet er altså hverken alene et problem i forhold til den gamle Kritiske Teori, eller alene et helt generelt og quasi transcendentalt problem for en samfundsteori, der hverken vil være reduktiv eller vil undgå totaliseringer, problemet er tillige realhistorisk accentueret. Således siger Habermas vedrørende rationalitetsproblemet i Vorwort i den nye bog: »Det tidshistoriske motiv 
ligger lige for. De vestlige samfund har siden slutningen af 60'erne nærmet sig en tilstand, hvor den occidentale rationalismes arv ikke længere har ubestridt gyldighed. Stabiliseringen af de interne forhold, som er opnået på grundlag af det socialstatslige kompromis, giver nu anledning til voksende socialpsykologiske og kulturelle omkostninger; også den for en tid fortrængte, men aldrig overvundne labilitet i forholdet mellem supermagterne træder stærkere frem i bevidstheden. For teoretisk at forarbejde disse fænomener, må man give sig i kast med de vestlige traditioners og inspirationers substans.« (Th.d.k.H,I,pg.9).

At problemet er accentueret i dag ses ikke alene i forhold til de sociokulturelle og politiske eksempler, som Habermas giver ovenfor: det er også tydeligt $\mathrm{i}$ forhold til en række intellektuelle positioner i dag, hvor anti-rationalismen er kommet i højsædet. Jeg siger ikke irrationalisme, men anti-rationalisme. Man kan her nævne poststrukturalistiske positioner samt mere generelt postmodernistiske positioner. Skønt man her ofte vil finde en umiddelbar affinitet til den gamle Kritiske Teori, hvad angår rationalitetskritikken, og man ikke kan undlade at gøre opmærksom på, at en af grundene til at den gamle Frankfurterskole atter er kommet på mode internationalt, sikkert ligger i dens umiddelbart tilsyneladende store disponibilitet til at blive taget til indtægt af postmodernistiske og poststrukturalistiske opfattelser, så er der en helt fundamental forskel: at f.eks. Adorno afviser muligheden af en systematisk begrundelse af fornuften, er jo ikke det samme som at han afviser fornuftsbegrebets implicit normative status - som Habermas så rigtigt gør opmærksom på. Denne Adornos stilling er helt parallel med hans afvisning af absoluta, side om side med hans emfatiske understregning af sandhedsbegrebet. Den postmodernistiske assimilering af f.eks. Adorno har således mest karakter af en annektion.

Som nævnt er rationalitetsproblemet accentueret og radikaliseret i dag, teoretisk såvel som realhistorisk. Der er tale om en reaccentuering, ikke om et novum: rationalitetsproblemet er selve grundproblemet i moderniteten. I talen i forbindelse med modtagelsen af Adornoprisen - »Die Moderne ein unvollendetes Projekt « fra 1980 - der rummer selve grundtankerne i Kommunikationsbogen siger Habermas: »Projektet om det moderne (Das Projekt der Moderne), som er blevet formuleret i det 18. århundrede af oplysningsfilosofferne, består i at udvikle de objektiverende videnskaber, det universalistiske grundlag for moral og ret og den autonome kunst $\mathrm{i}$ deres respektive egenart, men det består også samtidig i at løse det kognitive potentiale, som således ophobes, fra dets esoteriske højformer og gøre det nyttigt for praksis, dvs. en fornuftig udformning af livsforholdene. Oplysere af Condorcets støbning havde en overdreven forventning om, at kunst og videnskab ikke blot ville fremme kontrollen over naturkræfterne, 
men også omverdens- og selvfortolkningen, det moralske fremskridt, de samfundsmæssige institutioners retfærdighed, og sågar den menneskelige lykke.

I det 20. århundrede er der ikke meget af denne optimisme tilbage. Men problemet består, og nu som tidligere er de lærde uenige om, hvorvidt man skal holde fast ved oplysningens intentioner, hvor brudt dette end sker, eller opgive projektet om det moderne (Kleine politische Schriften I-IV, Ffm 1981, pg. 453). At Habermas holder fast i dette Aufklärungsprogram er hans sidste bog et heroisk bevis på.

Jeg har her peget på tre forhold, der kan bidrage til Habermas' reaktualisering:

I) Den generelle konservatisme, som i dag synes at være i fremmarch samtidigt med erkendelsen på venstrefløjen (når der tænkes totaliserende) af nødvendigheden af det lange tidsperspektiv i evolutionsprocesserne.

II) Marxismens status i dag, hvor den partikommunistiske model synes mere civilisatorisk anfægtet end nogensinde før og i tillæg hertil denne traditions problematiske receptionsramme for udviklingen af en aktuel marxisme. Måske skal man endvidere her pege på, at der internationalt side om side med forfaldet i tiltrækningskraften for den traditionelle partikommunistiske model og teoritradition, er sket et markant fald i de venstremarxistiske positioners udvikling og teoriarbejde. Habermas kan her - hvor underligt det end lyder - sikkert få en funktion som en art igangsætter af en fornyet diskussion.

III) Rationalitets og modernitetsproblemet.

Jeg vil her vove den påstand, at aktualiteten i Habermas' anliggende langt snarere ligger $i$ hans sammenhængende intervention $i$ disse tre problemkomplekser end i hans partielle løsningsforslag. Med aktualitet forstår jeg her aktualiteten i en socialistisk-intellektuel tradition. Det er den sammenhængende intervention, der gør hans arbejder uomgængelige i dag, i hvert fald for intellektuelle socialister på venstrefløjen, som stadig mener, at det i ikke-reduktiv forstand er nødvendigt med en - som regulativ idé i det mindste - totaliserende samtidsanalyse. Og måske er det frem for alt det omfattende fors $\emptyset \mathrm{g}$, netop nu, på at sammentænke de tre problemkomplekser, der mere end noget andet giver den nye bog aktualitet. Lidt flot sagt: det nye i den nye bog er først og fremmest det omfattende sammenhængstænknings-forsøg samt »tidsåndens « indflydelse. 
For ser man på de enkelte momenter i konceptionen, så er der tale om en forbløffende kontinuitet hos Habermas. Well, der er også enkelte meget afgørende, forskydninger og nuanceringer, ser man på det enkelte moment, hvor der også ofte forekommer en mere udførlig argumentation end før set; men stort set er der tale om en syntetisering, nu ikke primært af elementer fra andre teoritraditioner, men fra Habermas egen udviklingshistorie.

Illustrativt, og ikke fuldstcendigt om det nye:

I) Der er tale om en mere udførlig gennemarbejdning af den klassiske sociologis konceptioner.

II) Der er tale om en uddybning om mere omfattende diskussion af universalpragmatikken.

III) Begrebet »Moderne « er rykket helt frem i focus, ikke bare som intention, men som genstandsområde. I tilknytning hertil er den generelle evolutionsteori - forekommer det mig - neddæmpet.

IV) Der er en fremragende videreførelse af Weberansatsen fra »Teknik og Videnskab som Ideologi«, hvor den tysksprogede venstremarxismes reifikationsproblematik nu systematisk søges relateret til Webers rationaliseringsteser. (Efter min mening er dette bogens fineste enkeltanalyse).

V) Der er tale om en ekspliciteret genoptagning af den gamle 30 'ernes - Frankfurterskoles program, og i tilknytning hertil en for første gang systematisk anlagt kritik af den »klassiske Frankfurterskole « (30'erne) samt dens udviklinger i de to næste faser (»Dialektik der Aufklärung « og »Negative Dialektik«, samt i tilknytning hertil den overvejende kultur- eller kunstkritik). De to ting hænger sikkert sammen: den ekspliciterede genoptagelse af det gamle program nødvendiggør den systematisk anlagte kritik, som igen er muliggjort gennem en række arbejder fra andre traditioner vedrørende Frankfurterskolen. Således siger Habermas i det nye forord til »Philosophischpolitische Profile « fra 1980: »Dernæst findes der, fra mine nærmere omgivelser, skarpsindige analyser, som kaster lys over mine egne intellektuelle afhængighedsforhold, f.eks. mit forhold til Adorno, analyser, som skaber pludselig klarhed... Det forklarer, hvorfor jeg nu, som det fremgår af nekrologen over Marcuse eller beretningen om Horkheimer og Zeitschrift für Sozialforschung, forholder mig analytisk til Frankfurter-tra- 
ditionen og forsøger at vende tilbage til den kritiske teoris dannelsesperiode. »Oplysningens dialektik « har længe spærret for udsynet til dette oprindelsestidspunkt.« (op.cit.pg. 11, Ffm 1981).

VI) Der er tale om en langt større pointering af den økonomikritiske Marx' særegenhed end hidtil og i tillæg hertil en uudtalt, men nok så uafviselig perspektivforskydning fra den historiematerialistiske til den økonomikritiske Marx. Det er sikkert mere end en flothed, at slutbetragtningen har overskriften: »Von Parsons über Weber zu Marx« (bd.II, pg. 445). Lige som det i Habermas' regi er noget nyt, når han kan fastslå: »Den marxske ansats' teoristrategiske overlegenhed i forhold til de senere udviklede ansatser på samme abstraktionsniveau skyldes et genialt kup: analysen af vareformen« (bd.II, pg. 492). Her har Habermas stiltiende lært noget af den tradition, han lagde sig ud med i begyndelsen af 70'erne. Systematisk har denne nyopprioritering (der jo ikke foregår kritikløst, men som altså ikke desto mindre er tilstede) sikkert sammenhæng med to forhold: 1) at det er »die Moderne «, som er i focus og 2) at den generelle evolutionsteori nu figurerer mere som en rammebetingelse end som selve grundspørgsmålet. Endelig kunne man for det tredie nævne, at Habermas nu er blevet eksplicit civilisationskritikker. Jeg mener dog, at tyngdepunktsforskydningen fra den historiske materialismes Marx til den $\emptyset$ konomikritiske ikke alene skyldes forskydningen i tematik, men også skyldes en potentiel og latent teorirevision vedrørende Marx og en reel og intentionalt udtalt tilknytning til den klassiske Frankfurterskole fra 30'erne; det sidste fører næsten automatisk det første med sig.

VII) Der forekommer en markant forskydning fra den tidligere kredsen omkring legitimationsproblemer til kolonialiseringsteserne i samtidsdiagnosen. Der er ikke tale om et brud, men om en signifikant forskydning - og denne er vel atter partielt impliceret af (eller den anden vej rundt: betingende for) den ekspliciterede genoptagelse af Frankfurterskolens program fra 30'erne.

Som sagt: denne liste er ingenlunde komplet eller indiskutabel, den forekommer mig at være i det mindste illustrativ for min læsning af »den nye Habermas «.

\section{Kommunikativ handlen, historisk materialisme og civilisationskritik}

Habermas kritik af den historiske materialisme har to adskillelige, men dog samhørende momenter: for det første kritiserer han dens historiefilosofiske antagelser og randbetingelser, for det andet kritiserer han den 
for dens implicitte reduktionisme. Denne dobbeltsporede kritik kan føres tilbage til slutningen af 60'erne; den er fastholdt og udviklet siden da, og opnåede et hidtidigt højdepunkt $\mathrm{i}$ bogen »Zur Rekonstruktion des historischen Materialismus « fra 1976. Pointerne er fastholdt, men vel næppe længere selve det primære genstandsområde i den nye bog.

Lad os kort rekapitulere hans standpunkter.

Omkring den implicitte historiefilosofi, siger han i »Zur Rekonstruktion...«: »Den hidtidige verdenshistories curriculum, som opviser en sekvens af fem eller seks produktionsmåder, fastlægger den ensrettede, nødvendige, uafbrudte og opstigende udvikling af et makrosubjekt. Jeg skal overfor denne model for artshistorien opstille en lidt afsvækket version, som ikke kan rammes af de kendte indvendinger mod den historiefilosofiske tænknings objektivisme« (pg. 154).

Jeg skal her ikke gentage standardkritikkerne overfor den traditionelle historiefilosofi. Dem har - undskyld mig - $\varnothing$ konomikritikken udfoldet lige fra sin start. Og jeg anser dem for helt og aldeles holdbare. Hvad der imidlertid er interessant ved Habermas' forehavende er ikke så meget hans opgør med historiefilosofien som substrat for den historiske materialisme, men at han ikke bliver stående herved. Man kan sikkert sige det således, at Habermas opfattelse er den, at godt nok var den traditionelle (dvs. oplysningsfilosofiske) historiefilosofis idé en fiktion, men dens intention var ikke en meningsløshed. Man kommer ikke uden om at diskutere fremskridt, man kommer ikke uden om et evolutionsbegreb for sociale processer, hvis og når man aktuelt vil gennemføre en i sin tendens totaliserende samtidskritik med det mål at bidrage til en universal og almen emancipation. Derfor kan Habermas også sige: »Jeg vil derfor argumentere for den tese, at det systematisk er muligt at retfærdiggøre kriterierne for det historiske fremskridt, som i den historiske materialisme udpeges som produktivkraftudviklingen og de samfundsmæssige forholds modenhed.« (op.cit. pg. 156-7).

Lad os sammenfatte: Habermas evolutionsteori, som han forsøger at udbygge, nu primært indenfor rammerne af »Die Moderne «i den nye bog, har to begrundelser, en teoriintern og en kritikintentional. Teoriinternt er det nødvendigt med en evolutionsteori for rationaliteten, hvis og når universalpragmatikkens normative status ikke skal opnås via en transcendentalfilosofisk argumentation. Og Habermas ønsker at undgå den transcendentalfilosofiske argumentation. Måske kan man sige, at han allerede har lært dette af Gadamers historisering af Sinnbegrebet i hans kritik af fænomenologien (Husserl og Schütz). For det andet er evolutionsteorien uomgængelig for en samtidskritik, der intenderer totaliseringer. Som bekendt lader Habermas sig til forsvar for evolutionsteorien inspirere af 
den genetiske strukturalisme a lá Piaget og Kohlberg. Han arbejder her i homologien mellem onto og fylogenesen. Og det er nok det immanent svageste led i hans argumentation.

Foreløbig sammenfatning: Habermas behøver en omfattende evolutionsteori for at muliggøre den systematisk anlagte begrundelse af fornuftens normative status og for at muliggøre en totaliserende samtidsanalyse. Han afviser den traditionelle historiske materialismes historiefilosofiske begrundelse for denne dobbeltsporede proces, og han erstatter histomaten med en evolutionsteori, der er forpligtet på universalpragmatikken.

Som projekt forekommer det mig, 1) at hans kritik af den historiske materialisme er uafviselig, 2) at han har ret i nødvendigheden af et alternativ, altså et alternativt evolutionsbegreb, men at han er problematisk i sin begrundelse. For det tredie forekommer hans anvendelse af universalpragmatikken som led i en fornuftskritik mig at være central. Man skal her nemlig passe på ikke at reducere problemet til et sprogfilosofisk, men man må kunne se dels den teoretiske baggrund og dels hans forsøg på at aktualisere Kants tredelte fornuftskritik under inspiration fra Hegel/Marx. Det er denne kritik, der er med til at sikre aftranscendentaliseringen af fornuftskritikken.

Habermas' anden kritik imod den historiske materialisme går på dens påståede reduktionisme.

Allerede i slutningen af 60'erne (bl.a. i artiklen »Technik und Wissenschaft als Ideologie «) fremførte Habermas under inspiration fra Hegel en kritik af den historiske materialismes tendentielle reduktion af evolutionshistoriens motorik til udviklingen i arbejdet (produktivkræfternes udvikling). Han foreslog dengang, at man oprettede en irreduktibel distinktion mellem arbejde og interaktion. Senere, $i$ »Zur Rekonstruktion...« udviklede han sin såkaldte Schrittmachertese (gentaget f.eks. pg. 222-223 i Th.d.k.H. bd. II), der siger: »Rationalitetsstrukturer materialiserer sig ikke blot i den målrationelle handlings forstærkere, altså i teknologier, strategier, organisationer og kvalifikationer, men også i den kommunikative handlings formidlinger, i konfliktreguleringsmekanismerne, i verdensbillederne, i identitetsdannelserne. Jeg vil sågar forsvare den tese, at udviklingen af disse normative strukturer er den sociale evolutions foreløber (Schrittmacher), idet nye samfundsmæssige organisationsprincipper indebærer nye former for social integration; og først disse muliggør gennemsættelsen af eksisterende eller frembringelsen af nye produktivkræfter samt en øget samfundsmæssig kompleksitet.« (op.cit. pg. 35).

Som man kan se, er denne tese, og den fundamentale distinktion mellem arbejde og interaktion fastholdt i den nye bog. Dog med centrale modifikationer og udbygninger. Men generelt gælder, at de to poler arbejde 
og interaktion er fastholdt som base for den nye, mere differentierede, men også mere abstrakte distinktion mellem »System und Lebenswelt«. Umiddelbart sker der i det nye arbejde først og fremmest en udvikling i interaktionsbegrebet: dels præciseres selve interaktionsbegrebet i form af dets indsætten i en fylo- og ontogenetisk ramme plus at nyere sen Wittgensteinske pointer søges inddraget, og dels udvides og specificeres selve det rationalitetsbegreb, der oprindeligt rummede hele interaktionslogikken til to indbyrdes irreduktible rationalitetsformer: den moralsk-normative og den æstetisk-ekspressive. Det nye er her helt fundamentalt opkomsten hos Habermas af en evolutionshistorisk betinget æstetisk-ekspressiv rationalitetsform.

Man kan måske sammenfattende sige, at nu er »rekonstruktionen« af Kants tredeling i fornuften: den kognitive, den moralske og den æstetiske, gennemført indenfor rammerne af en teori om den kommunikative handlen, der hviler på evolutionsteoretiske antagelser. Uddifferentieringen af en ekspressiv rationalitetsform ved siden af den normative og den kognitive kan dels ses som en sagen analytisk iboende nødvendighed, og dels - og det er nok vigtigere - må den ses som en nødvendig konsekvens af, at det nu er »die Moderne « som er i focus. Meget vigtigt, såvel intentionalt som kontrastivt til den gamle Frankfurterskole er Habermas' dobbeltsporede forsøg på at analysere »die Moderne«. Denne dobbeltstrategi kan måske kort udtrykkes således: det drejer sig på en gang om at få fat i de uafviselige nydannelser, som manifesterede sig i forbindelse med modernismen, samtidigt med, at det er tvingende nødvendigt ikke at lade modernismen have patent og monopol på moderniteten. Modernismen har accentueret og forstærket elementer i moderniteten, derfor kan og skal den ikke overses eller reduceres, men hvis den får patentet på moderniteten, altså hvis den i rekonstruktionen selvstændiggøres og isoleres, forstiller den blikket på moderniteten, som den alene er en konsekvens af og et partikulært udtryk for. Habermas' uddifferentiering af den æstetiskekspressive rationalitet $\mathrm{i}$ forhold til den kognitive og den normative er en konsekvens af denne grundliggende opfattelse, som han måske mest kategorialt og klart har udtalt i forbindelse med talen omkring Adornoprisen, og her med direkte adresse til Adorno. Modernitetsproblematikken artikuleres sammenhængende og overgribende i det 18. århundrede. Modernismen skabes fra det 19. årh. som en følge heraf: den er nok en nydannelse, men inden for rammerne af den allerede et århundrede før grundlagte problematik. Modernismen må således ses i dette perspektiv, ikke som en selvstændiggørbar, alene reaktiv nydannelse på den moderne kapitalisme.

Kort sagt tror jeg, at man kan sige, at Habermas i højere grad end f.eks. Frankfurterskolen før ham, adskiller modernismefænomenet i to størrelser: 
en eksistentiel og en formel (formsprog). Det nye formsprog som vindes i modernismen i forbindelse med kunstens desutilisering ses her ikke som reducerbar til den eksistentielle problematik, det opstår i forbindelse med: det er ikke kun en eksistentiel reaktion på storbylivets fremmedgørelser, men rummer for første gang og nu irreversibelt den æstetisk-ekspressive rationalitets frigørelse fra de andre rationalitetsformers dominans. Som kunst er det altså ikke alene eller primært analyserbar som protest, idet det også rummer et irreversibelt moment, der overskrider protestens situation. Derimod gælder, at den eksistentielle problematik, som det altså opstår ud fra, og accentueres i forhold til, i højere grad knytter sig til, om man vil, de mere klassiske træk af moderniteten, således som disse f.eks. er bearbejdet hos Hegel og ikke mindst Kierkegaard i forbindelse med den æstetiske livsholdning. Modernismen bliver herved eksplicite indlejret $\mathrm{i}$ en modernitetskritik, der tillige reetablerer det gamle 30'er program for Frankfurterskolen. Kunstkritikken bliver herved systematisk integretet i en bred civilisationskritik. En vigtig udtalelse fra omtalte Adornotale lyder: »I den kommunikative hverdags-praksis må kognitive fortolkninger, moralske forventninger, udtryk og vurderinger gennemtrænge hinanden. Livsverdenens forståelsesproces har brug for en kulturel overlevering i bred forstand. Derfor vil en rationaliseret hverdag ikke kunne frelses fra stivnet kulturel forarmelse ved at et kulturelt område, i dette tilfælde altså kunsten, åbnes med magt og ved at, der skabes en tilslutning til et af de specialiserede kundskabskomplekser. På denne måde kan man kun erstatte én ensidighed og én abstraktion med en anden«. (Kleine pol. Schr., pg. 458).

Med denne tredeling i rationaliteten, og med insisteringen på, at modernitet ikke går op i modernisme forsøger Habermas at reaktualisere en ikke-reduktiv rekonstruktion af den historiske materialisme med focus på moderniteten, altså som civilisationskritik. Og det er herved, at han mener at kunne knytte an til Frankfurterskolens 30'er program, nemlig omkring udviklingen af en samfundsvidenskabeligt bredt funderet og orienteret kritik, der hverken forkommer til scientivisme eller filosofi, men som heller ikke højstilliserer den instrumentelle fornuft på en sådan måde, at civilisationskritik bliver de facto reduceret til kunstkritik.

Det forekommer mig, at Habermas' kritik af reduktionismerne i den traditionelle historiske materialisme er korrekt - lige gyldigt, om man også kan påpege, at der hos Marx forekommer en række udtalelser, som modsiger denne reduktionisme. Problemet er jo dels, at det er uafviseligt, at denne reduktionisme har været dominerende i II og III Internationale regi, og dels, at der hos Marx på det kategoriale niveau også forekommer sådanne reduktionismer, samtidigt med at han i de materiale analyser godt nok praktiserer noget andet. 
Man har ofte anført, at Habermas overser, at arbejde også allerede hos Marx involverer interaktion. Dette er kritikken som allerede Krahl gjorde opmærksom på. Det er rigtigt, men anfægter ikke pointen hos Habermas, så vidt jeg kan se: for selv om arbejde også altid allerede involverer interaktion og kommunikation, så er dette ikke en tilstrækkelig begrundelse imod analytisk at adskille dem. Lige så lidt som der ikke skulle være grund til analytisk at adskille Marx' to arbejdsbegreber (Arbeit og travail attractif), således som de fordeler sig på Marx' to »riger « nødvendighedens og frihedens, der jo også, som Habermas påpeger, er symmetriske med distinktionen mellem »System « og »Livsverden «.

Generelt vil jeg sige, at det ikke forekommer mig, at det er lykkedes Habermas at give nogen systematisk på en evolutionsteori baseret begrundelse for fornuftens normative status. Hertil er hans homologioperation alt for argumentativt flygtig og problematisk. Men han har med dette fors $\emptyset \mathrm{g}$, forekommer det mig, faktisk medvirket til det, som var hans intention, en genoptagelse af 30'programmet for Frankfurterskolen. Her kan hans opfattelser anvendes heuristisk og som regulativ tese. Og for så vidt forekommer det mig, at vi her har at gøre med en respektingydende kompleks og også genstandssensitiv civilisationskritisk teori, der fortjener at blive taget op, når og hvis man i øvrigt beskæftiger sig med fænomenet civilisationskritik. Bogen er ikke bare intellektuelt informativ i respektindgydende forstand (men det er den altså også): den giver en række teser og inspirationsbaser for en udvikling af en marxistisk civilisationskritik. 



\section{KOMMENTARER OG}

ANMELDELSER: 


\section{Teknologisk udvikling og økonomiseringsformer}

\section{Diskussion af problemer i bogen: Teknologisk forandring og industriudvikling af Povl A. Hansen, Henrik Toft Jensen og Göran Serin.}

\section{Allan Andreassen*}

Diskussionen af den teknologiske udvikling og dens konsekvenser for arbejderklassen har siden krisens gennemsættelse taget til både i omfang og emner. »Teknologisk forandring og industriudvikling « $^{1}$ repræsenterer et af de få eksempler på en marxistisk inspireret konkret analyse, som har forsøgt sig med en mere sammenfattende analyse af de seneste års udvikling $\mathrm{i}$ industrien ${ }^{2}$.

Det er forfatternes hensigt med bogen at bevæge sig ud over det de opfatter som de hidtidige to analyseretninger i studiet af den teknologiske udvikling, industrisociologien med den focusering på relationen mellem arbejder og maskine (det må vel være arbejdssociologien de tænker på) og ingeniørvidenskaben, som beskæftiger sig med teknik ... »uden at denne udviklings drivkraft og konsekvenser for andre forhold i arbejdsprocessen analyseres « (side 7).

Der kan derfor være god grund til at diskutere om bogen bevæger sig ud over de to analyseretninger og formår at indløse det ambitiøse projekt med at analysere industriens teknikudvikling.

Indledningsvis skal det lige præciseres at følgende diskussion i hovedsagen drejer sig om bogens mere sammenhængende analyse af arbejdsprocessens udvikling, fra kapitel 6-10. Den $\emptyset$ vrige del af bogen er af mere beskrivende karakter, f.eks. er der et længere afsnit om »Den industrielle produktionsstruktur i Danmark «, som på den ene side ikke viser produktionsstrukturens udvikling, men som væsentligst er en gennemgang af »tiårsoversigtens« tal for beskæftigelsesudviklingen $\mathrm{i}$ industriens bran-

* Denne kommentar er skrevet på basis af et diskussionsoplæg til forskningsprojektet »Den teknologiske udvikling og dens konsekvenser i samfundsmæssig belysning«, Institut for Miljø, Teknologi og Samfund, Roskilde Universitetscenter.

1. Povl A. Hansen, Henrik Toft Jensen og Göran Serin: Teknologisk forandring og industriudvikling, GEO/RUC 1982.

2. Mig bekendt findes der udover bogen kun: Jørgen F. Lauridsen m.fl.: Teknologi, arbejdsorganisation og kvalifikation- og udviklingen i den danske industri efter 1950. RUC, Tek/Sam 1977. 
cher, suppleret med oplysninger fra varestatistikken. På den anden side har beskrivelsen af den såkaldte strukturudvikling ikke sammenhæng med bogens analyse af den tekniske udvikling.

I forhold til diskussion og kritik af bogen vil jeg nøjes med at tage tre punkter op: 1) anvendelsen af subsumtionskategorierne i forhold til den historiske teknikudviklingstendens, 2) anvendelsen af arbejdsfunktionsbegrebet i forhold til teknikudviklingen, 3) sammenhæng mellem profitproduktionsmetoder og den tekniske udvikling.

\section{Den reelle subsumtion}

I bogens kapitel 7, Teknisk udvikling, arbejdets organisering og teknologiseringen af arbejdsprocessen, diskuteres udgangspunktet for en opfattelse af den kapitalistiske produktionsmåde og teknikudviklingen, som forfatterne mener skal undersøges på basis af udviklingen i subsumtionen af arbejdsprocessens tre elementer: arbejdskraft, arbejdsmidler og arbejdsgenstand. Det præciseres at den reelle subsumtion, som historisk tendens, udvikler sig i tre faser som står i forbindelse med hverandre. De tre faser fremgår af figuren:

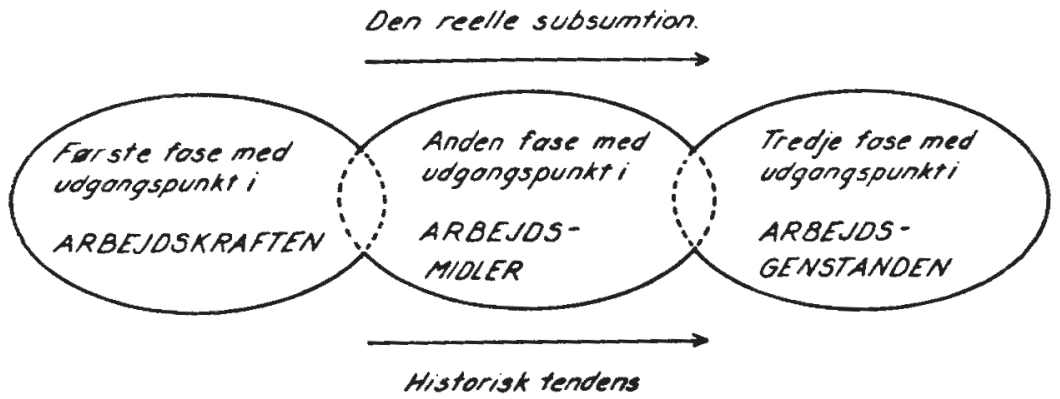

Kilde: Povl A. Hansen m.fl.: op.cit.

Det nye i forhold til de begreber Marx anvender i første bind af Kapitalen og i »Resultater « ${ }^{3}$, er den såkaldte tredie historiske tendens, hvor arbejdsgenstanden subsummeres; en fase, som iflg. forfatterne, begynder under den anden fase, hvor arbejdsmidlet er udgangspunktet for omvæltningerne.

3. Karl Marx: Kapitalen, kapitel 11-13 bd. 1:2 og 1:3, Rhodos 1970 og Karl Marx: Resultater af den umiddelbare produktionsproces, Modtryk 1974. 
»Denne fase har sit udgangspunkt (i) de problemer, der eksistere for en videre mekanisering ( $\mathrm{min}$ fremh.) på den eksisterende arbejdsgenstands grundlag. For at løse dette problem udvikles nye stoflige former, der enten giver mulighed for forandrede mekaniske processer eller gør det muligt at fjerne visse af disse. Udviklingen af plastikken, syntetisk klædestof og forskellige hjælpestoffer er typiske eksempler på denne udvikling « (side 88).

Historisk set er det korrekt at arbejdsgenstanden forandres indenfor forskellige industrigrene med nye stoflige former til følge, hvilket netop er et af de forhold som kendetegner storindustriens princip med naturvidenskabernes anvendelse på produktionen ${ }^{4}$. Imidlertid ændrer formforandringen af arbejdsgenstanden ikke ved det forhold, at maskinen er udgangspunktet for omvæltningerne under den storindustrielle fase. Derfor er det ikke hensigtsmæssigt at udskille en særlig tredie subsumtionsfase; formforandringen af arbejdsgenstanden hører den storindustrielle fase til.

Forandringer af arbejdsgenstanden har haft betydning indenfor produktioner, hvor hhv. arbejdskraften og maskinen, har dannet udgangspunkt. Derfor er ændringer i arbejdsgenstanden ikke kun som fremhævet af forfatterne, et spørgsmål om videre mekanisering, men har i nogle tilfælde dannet udgangspunkt for en overgang fra en manufakturel til storindustriel produktionsform i nogle industrigrene/-brancher. To eksempler kan belyse det nærmere.

I skibsværftsindustrien betød overgangen fra nitning til svejsning af plader i 1940 og 50'erne hverken en mekanisering eller videre mekanisering, men derimod en forandring af arbejdsgenstanden; nitterne forsvandt og pladernes kanter blev modsat tidligere skåret i vinkler, så der kan lægges svejsesøm. Indførelsen af svejsning krævede også en ny form for håndværktøj. Svejsningens større styrkeegenskaber frem for nitning af plader har siden overgangen ført til andre ændringer i arbejdsgenstanden, f.eks. har nye stålkvaliteter skabt grundlag for anvendelse af tyndere plader. Indførelsen af svejsning i skibsværftsindustrien har primært været et spørgsmål om økonomisering med den flydende konstante kapital, men med svejsningen skabtes grundlaget for mekanisering af svejsningen. Imidlertid varede det omkring 20 år før mekaniseringen overhovedet viste sig som en profitproduktionsmetode i skibsværftsindustrien; produktionsformen indenfor sammenføjningen af plader er dog stort set stadigvæk manufakturel. 
Indenfor elektronikindustriens printmontage har forandringen $\mathrm{i}$ arbejdsgenstanden bestået $i$, at klembrættet blev afløst af printpladen, hvor ledningsføringen er ætset i printet. Dette betød ikke kun fjernelse af manuelle arbejdsfunktioner i samlingen af sytøj og ledningsføring på klembrættet, men en betydelig udvidelse af kooperationen i printmontagen. Udviklingen af printplader og standardisering af komponenter til printpladen, som primært skete i starten af tresserne, dannede udgangspunkt for mekanisering af arbejdsfunktionerne i montagen, men i første omgang et nyt grundlag for arbejdsintensiveringer gennem den nye arbejdsdeling, som den væsentligste profitproduktionsmetode i elektronikindustrien fremfor mekanisering. I midten af tresserne mekaniseredes transporten i printmontagen og først i slutningen af dette årti standsede virkningerne af arbejdsintensiveringerne med mekanisering af forskellige arbejdsfunktioner til følge. ${ }^{5}$

Da arbejdsgenstanden er en central kategori for bogens forfattere i forhold til bearbejdningsformer og subsumtion, fremkommer der på basis af en analyse af bearbejdningsformer 9 forskellige som skulle dække alle industriens bearbejdningsformer. Det drejer sig om: stofudvinding, stofforberedelse, stofforandring, stoftilstandsformsforandring, stofformning, stofbearbejdning, stofblanding, montage og indpakning.

\section{Den tekniske udvikling}

Typologiseringen af bearbejdningsformerne anvendes i en empirisk analyse af den »Tekniske udvikling og arbejdsfunktionernes forandring «, hvor disse sammenfattes til 3 arbejdsprocestyper, som hver for sig hævdes at skulle give specielle muligheder..., »men som samtidig sætter specifikke rammer for den tekniske forandring.« (side 154).

Følger man denne tankegang er der samme muligheder for tekniske forandringer indenfor eksempelvis arbejdsprocestypen materialeformning (stofforberedelse, stofbearbejdning og stofformning), da disse arbejdsprocestyper iflg. forfatterne karakteriseres ved. . »ensartet form for og kombination af de tre elementer i arbejdsprocessen og dermed også ensartede arbejdsopgaver « (side 153).

Tager vi f.eks. stofbearbejdning kan der umulig eksistere ens arbejdsopgaver på en metalvirksomheds spåntagende produktion og et slagteris produktion med udbenning af skinker, fjernelse af ribben fra brystsiden, tarmrenseri m.v., alene ud fra det forhold, at arbejdsgenstanden på et slag-

5. Allan Andreassen; Lønformer og produktionsformer i industrien, RUC Tek/Sam 1980 og Ilse Nielsen m.fl.: Montageprocesser i elektronikindustrien, RUC Tek/Sam 1980. I sidstnævnte projektrapport findes resultatet af en spørgeskemaundersøgelse fra 14 af de største danske elektronikvirksomheder om mekanisering i printmontagen og indførelsestidspunktet for disse. 
teri modsat et stykke stål præcise form, har en tendens til at være meget uens. Bogens empiriske materiale åbner iøvrigt ikke mulighed for at konstatere om der findes samme muligheder for tekniske forandringer i nogle af de tre arbejdsprocestyper, som de 9 forskellige bearbejdningsformer sammenfattes i.

For det første er den empiriske analyse ikke opbygget med udgangspunkt i udviklingen af produktionens teknologiske grundlag indenfor industrier/brancher i en repræsentativ form. For det andet er den historisk forkortet til kun at omfatte udviklingen indenfor de seneste år.

For den processerende arbejdsprocestype eksempelvis, sukkerfremstilling, brygning, fremstilling af kemiske produkter, får læseren ingen indsigt i hvordan produktioner forløber og hvordan de tekniske ændringer i disse industriers produktionsprocesser konkret er gennemsat historisk set. Informationerne om produktionerne er så sparsomme, at man kan nemt kan få den opfattelse, om nu også forfatterne har den fornødne indsigt?.

De spredte fægtninger, med eksempler hist og her på tekniske ændringer, får også konsekvenser for forholdet mellem arbejdsfunktioner og den tekniske udvikling.

I den empiriske analyse af udviklingen i arbejdsfunktionerne og den tekniske udvikling anvender forfatterne Kern og Schumanns arbejdsfunktionsbegreb i den form Mendner benytter sig af $^{6}$, som i forhold til forskellige perioder af den tekniske udvikling kan sammenfattes i følgende skema:

De almene arbejdsfunktioners karakter $i$ forskellige perioder af den tekniske udvikling

\begin{tabular}{|l|c|c|c|c|}
\hline & hoved funktion & sidefunktion & for beredelses funktion & kontrol og korrigering \\
\hline hanndværksperioden & manuel & manuel & manuel & manuel \\
\hline mekanisering & maskinel & manuel & manuel & manuel \\
\hline halvautomation & maskinel & maskinel & manuel & manuel \\
\hline helautomation & maskinel & maskinel & maskinel & maskinel \\
\hline
\end{tabular}

Kilde: Povl A. Hansen m.fl.: op.cit.

Systematiseringen af den tekniske udvikling på basis af arbejdsfunktionernes karakter rummer et væld af problemer, som i al sin enkelhed kan sammenfattes $\mathrm{i}$, at det ikke er muligt at systematisere på basis af arbejdsfunktionsbegrebet i konkrete historiske analyser af den tekniske udvikling

6. Jürgen Mendner: Teknologisk udvikling i den kapitalistiske arbejdsproces: Röda bokförlaget/ Kurasje 1976. Forfatterne fremhæver dog at de giver arbejdsfunktionsbegrebet en lidt anden betydning. 
i industrien. I anvendelsen af arbejdsfunktionsbegrebet fortabes samtidig den systematisk Marx benytter i fremstillingen af manufakturen og storindustrien. Et begreb som manufakturel produktionsform eksisterer slet ikke i periodiseringen af den tekniske udvikling hos forfatterne, se skemaet.

Det er selvsagt ikke muligt indenfor rammerne af denne kritik at vise omfanget af de problemer arbejdsfunktionsbegrebet rejser; kun nogle få konkrete eksempler kan illustrere problemerne. ${ }^{7}$

Indenfor en række industrityper, sukkerindustri, kemisk industri m.v., har der aldrig eksisteret det som forfatterne karakteriseres som en håndværksperiode med manuelle arbejdsfunktioner, hvor arbejderen med sit håndværkt $\varnothing j$ bearbejder et emne. ${ }^{8}$ Med hjælp af håndværkt $\varnothing j$ kan det slet ikke lade sig gøre at brygge $\varnothing 1$, raffinere sukker på basis af sukkerroer, fremstille benzin m.v., hvad forfatterne selv indirekte fremhæver i deres gennemgang af den tekniske udvikling og arbejdsfunktionernes forandring i den processerende arbejdsprocestype, uden at forbinde dette med deres udgangspunkt for systematiseringen af den tekniske udvikling:

»Det, som kendetegner den arbejdsprocestype er, at hovedfunktionen næsten altid har været mekaniseret. Den manuelle arbejdskraft har med få undtagelser aldrig haft nogen betydning for udførelsen af hovedfunktionen« (side 164).

Fastlæggelsen af overgangen fra den såkaldte håndværksperiode til mekaniseringsfasen, som i følge det førnævnte skema er tilendebragt når hovedfunktionen er maskinel, rummer tydeligvis andre begrebsmæssige problemer for forfatterne, fordi en del typer af værktøjsmaskiner ikke mekaniserer hele hovedfunktionen. En konventionel drejebænk f.eks. er afhængig af påvirkning fra arbejderen for at kunne bearbejde arbejdsgenstanden. Først med udviklingen af den numerisk styrede drejebænk (NS-maskinen) mekaniseres resten af hovedfunktionen. Således er den konventionelle drejebænk med forfatternes begreber, hverken håndværksmæssig produktion eller mekanisering af hovedfunktionen. Alligevel karakteriseres den konventionelle drejebænk som mekanisering, hvorimod NS-drejebænken betegnes som helmekanisering; altså et nyt begreb introduceres og benyttes.

7. Der findes også en diskussion af arbejdsfunktionsbegrebets anvendelse i forbindelse med konkrete analyser i: Tyge Kjær: Projektkommentar 4, Tek/Sam-forlaget 1979 og i Vibeke Andersen m.fl.: Realanalyse i krisen eller krise i realanalysen?, Kurasje nr. 25.

8. Retfærdigvis skal det nævnes, at begrebet hel- og delmekanisering er introduceret før gennemgangen af den materialeformende arbejdsprocestype. 
Betegnende for dette problem er, at flere maskintyper kun fjerner dele af arbejdsfunktionen, hvad udviklingen i de numerisk styrede maskiner igen kan illustrere, da de nye maskintyper i et vist omfang selv er i stand til at varetage kontrol og korrigering under bearbejdningen. På den baggrund skulle sammenhæng mellem arbejdsfunktioner og teknisk udvikling i førnævnte skema, udvides med begreber som hel, halv, kvart m.v. mekanisering af kontrol og korrigeringsfunktioner for at opfange ændringerne; det vil jo føre til opdeling i det uendelige.

Mekaniseringsfasen drejer sig imidlertid langt fra kun om at hovedfunktionerne bliver mere eller mindre maskinelle. Derimod har mekaniseringen i en del industrier/brancher bestået i sidefunktionen, transporten. Elektronikindustriens printmontage, hvor udviklingen i 1960'erne drejede sig om intensivering på basis af den nye arbejdsdeling, som blev resultatet af overgangen fra montering på klembræt til printmontage, skabtes der et udgangspunkt for mekanisering, jvf. tidligere. Den begyndende mekanisering af arbejdsfunktionerne startede med mekanisering af transporten mellem montricerne og udviklingen i 1970'erne har bestået i en videre mekanisering af den manufakturelle kooperation. På nogle virksomheder, hvor linieproduktionen er afløst af selvstyrende grupper, har den ændrede organisering af arbejdet ført til afskaffelse af transportbåndet mellem arbejderne i de indledende faser af printmontagen. I de selvstyrende grupper skiftes arbejderne til at kontrollere om komponenterne er monteret korrekt på printpladen, hvilket foregår på en halvautomatisk maskine. Korrektionsfunktionerne er manuelle, jvf. sammenlægningen af kontrol og korrigering i skemaet.

Begrebsanvendelsen medfører samme problemer når det drejer sig om sektionsfremstillingen på skibsværfter, da mekaniseringen af arbejdsfunktionerne i stor udstrækning kun har bestået i transporten (sidefunktionen) og kun få svejsefunktioner; resten af arbejdsfunktionerne i den manufakturelle produktionsform er manuelle. På slagterierne har mekaniseringen i den rene ende også kun bestået i transporten.

Sådan er det muligt at frembringe utallige eksempler på de problemer der opstår, når den tekniske udvikling undersøges på basis af arbejdsfunktionernes forandring.

\section{Profitproduktionsmetoderne?}

Det sidste problem vi skal tage op, som i virkeligheden kan føres tilbage til de forrige problemer, er bogens manglende inddragelse af profitproduktionsmetoderne i den empiriske analyse af den »Tekniske udvikling og arbejdsfunktionernes forandring $«$. Kapitlet indledes med følgende profitproduktionsmæssige overvejelser: 
»I det følgende skal vises, hvorledes kapitalen, dels gennem en mekanisering af arbejdsoperationerne, dels gennem arbejdsorganisatoriske foranstaltninger, forandre arbejdsprocessens tekniske niveau. Dette sker gennem en stigning i arbejdets produktivkraft eller gennem intensivering af arbejdet. De arbejdsorganisatoriske foranstaltninger kan også vise sig som økonomisering med den konstante kapitals flydende og faste bestanddele« (side 148.)

Et gennemgående træk i analysen af den tekniske udvikling og arbejdsfunktionernes forandring, som jo er struktureret omkring spredte eksempler indenfor de tre arbejdsprocestyper, er netop manglen på systematiske unders $\emptyset$ gelser af de konkrete profitproduktionsmæssige baggrunde for den tekniske udvikling og dermed hvorfor profitproduktionsmetoderne kan give sig udslag i en differentiering af det tekniske niveau hos enkelkapitaler/brancher.

Struktureringen af den empiriske analyse blokerer for profitproduktionsmæssige betragtninger. Derfor bliver de værdi/prismæssige overvejelser på stoflige ændringer kun forklaret som generelle fænomener, som kapitalens stræben mod at sænke den gennemsnitlige nødvendige arbejdstid i vareproduktionen. løvrigt kan det nævnes at der findes profitproduktionsmetoder som ikke sænker den gennemsnitlige nødvendige arbejdstid i vareproduktionen.

Overvejelser om produktivkraftudvikling og arbejdsintensiveringer foretages strengt taget heller ikke systematisk. Der undersøges ikke om de tekniske ændringer er udtryk for produktivkraftudvikling eller arbejdsintensiveringer, eller om produktivkraftudviklingen fører til arbejdsintensiveringer på det nye produktivkraftgrundlag; betragtninger som analysen istedet skulle være struktureret omkring, når hensigten med denne er at vise de kvantitative og kvalitative ændringer i arbejdsforholdene og arbejdskraftforbruget.

Denne katastrofale fremgangsmåde, hvor profitproduktionsmetoderne udelukkes, fører let til stoflige forklaringer på forandringer eller manglende gennemsættelse af disse. I bogens gennemgang af den sammensættende arbejdsprocestype, forklares de specifikke udviklingstræk med problemer i forhold til at indkorporere det sensoriske apperat i maskinen, hvad der således har betydet arbejdsintensiveringernes særlige kendetegn for denne arbejdsprocestype (side $197 \mathrm{ff}$ ).

Ud fra dette standpunkt skal eksempelvis forklaringen på, hvorfor overgangen fra nitning til svejsning $\mathrm{i}$ skibsværftsindustrien med håndværktøj, ikke i første omgang førte til mekanisering af svejsningen, reduceres til et spørgsmål om udvikling af svejsemaskiner, og ikke som det 
var tilfældet for skibsværfterne, nemlig at mekaniseringen af svejsningen ikke ville føre til kostprisreduktioner og dermed til en forbedring af profitproduktionen.

Indenfor andre virksomheder har der naturligvis hersket samme profitproduktionsmæssige skranker for produktivkraftudviklingen. I det omfang profitproduktionen kan forøges gennem intensivering af arbejdet på basis af arbejdsdelingen og andre metoder, hersker der ingen umiddelbar tvang for udvikling af arbejdets produktivkraft.

Dette er den virkelige baggrund for, hvorfor nogle virksomheder/brancher stadig kan karakteriseres som overvejende manufakturelle produktionsformer og ikke, som forfatterne kommer til at hævde, problemer med at udvikle maskiner. Kun konkrete historiske virksomheds- og branche analyser og de profitproduktionsmetoder der tages i anvendelse, kan afsløre disse sammenhænge. Det som forfatterne via deres forkortede og mangelfulde empiriske analyse har lukket af for.

\section{Afslutning}

Konklusionen på forfatternes opfattelse af tekniske forandringer, er udviklingen af en form for stoflig logik, hvor den konkrete tekniske udvikling bliver illustrationsmateriale for den logiske udvikling af faserne $\mathrm{i}$ den kapitalistiske produktionsmådes historie. Betragtningsmåden fører som vi har vist til generaliseringer, som ikke kan opfange den differentierede teknologiske udvikling hos enkelkapitaler/brancher, som er et resultat af de profitproduktionsmetoder der tages i anvendelse afhængig af den industrielle cyklus (ekstensiv-, intensiv-, overakkumulation).

I faserne under den industrielle cyklus er udviklingen af teknologien ikke givet på forhånd. Udviklingen forløber forskelligt fra enkelkapital til enkelkapital afhængig af deres konkurrencebetingelser, hvilket kun konkrete historiske analyser vil kunne opfange.

Inddragelsen af den industrielle cyklus gør det samtidig mulig at forstå, hvorfor arbejdsgenstanden forandres indenfor produktioner, som er manufakturel baserede.

Da forfatterne ikke har været istand til at undersøge de profitproduktionsmæssige årsager til teknikudviklingen er det min opfattelse at det giver to problemer i forhold til deres indledende intentioner. Strengt taget bevæger analysen sig ikke ud over ingeniørvidenskaben og mangler dimensionen, konkret kapitalismekritik. 


\title{
Det uendeligt store i det uendeligt små.
}

\section{Ideologikritik af ideologemet »snilde teknologier«}

\author{
Hans Jørgen Thomsen
}

\section{Fascinationen}

Det følgende er en om-tale af Jesper Hoffmeyers bog »Samfundets naturhistorie«, der i 1982 udkom på det nystartede forlag Rosinante, og som allerede er blevet en bestseller.

Det kan være, at stilen i denne omtale virker arrogant, men denne arrogance skal ikke misforstås. Jeg deler sigte med Jesper Hoffmeyer - politisk og et stykke af vejen også teoretisk. Jeg mener også, at Hoffmeyer har skrevet en god bog, men jeg vil lade andre om at gentage de hurraråb, som allerede er udbragt. I stedet vil jeg kritisere bestselleren, og det vil jeg måske gøre arrogant. Men det sker for at vække diskussion: også nok så »snilde teknologier « kan gøres til genstand for en rationel diskussion. Og måske ligger der mere ny historisk sandhed i en sådan diskussion end i teknologierne selv.

Ud over »Samfundets naturhistorie « vil jeg inddrage Tor Nørretranders' og Hoffmeyers artikler i tidsskriftet $»$ Naturkampen«, nr. 25.

De fleste kender sceneriet. Folk er blevet fulde, og nogle beslutter, at der skal spilles kort. Med slørede øjne og usikre bevægelser spilles kortene til langt ud på morgenen, og hvis der er tale om rutinerede kortspillere, spilles kortene ikke mindre præcist, fordi man er beruset. Snarere tværtimod.

Beruselsen skærper sansen for spillets logik. Det er som med to negative størrelser, der bliver til noget positivt, når de mulitpliceres med hinanden: kroppens beruselse ganget med dén beruselse, som spillets logik sætter i gang, fører til en næsten nirvanask sammensmeltning af krop, bevidsthed og spil.

Jeg vil gætte på, at fascinationen over de nye - såkaldt »snilde « - teknologier spiller en noget større rolle for den betydning, disse teknologier tildeles, end det normalt indrømmes. Naturvidenskabsfolk stråler ofte af begejstring over alt dét, som deres teknologi kan, og man kan godt forstå deres melankoli, når det ikke lykkes dem at overbevise andre om teknologiernes fortræffelighed. Det er næsten til at leve sig ind $i$, hvordan de må bruge alle mulige andre - antropomorfiserende - argumenter for at gøre denne fortræffelighed klar for lægfolk.

Behovet for at antropomorfisere den teknologiske logik - at oversætte dens indhold til menneskesprog - kommer tydeligvis fra dén aura, det tekniske spil udstråler, og som naturvidenskabsmanden eller teknikeren ofte har patent på at blive fascineret af. Naturvidenskabsmanden kan bjergtages af auraen i det teknologiske spil på en måde, der kan lede tanken hen på berusede kortspillere i en sen nattetime.

Forholdet gengiver en presserende oversættelsesproblematik imellem na- 
turvidenskaberne og human-, og socialvidenskaberne. En problematik, der også kendes fra humanog socialvidenskabernes behov for at gøre sig selv naturvidenskabeligt legitime.

Det ville være tradinionalisme at mene, at en udveksling imellem de ellers skarpt adskilte vidensfelter skulle være umulig. Jeg vil dog - for det første - mene, at der faktisk er grænser for, hvad eller hvilke dimensioner, det giver mening at udveksle, og det skyldes vidensområdernes basale forskelligheder (»det tekniske « contra »det menneskelige/sociale«).

For det andet vil jeg mene, at det er nødvendigt at gøre sig selve oversættelsesproblematikken klar, når man endelig søger at udveksle elementer, det giver mening at udveksle. Elementer, der måske ligefrem råber på udveksling på grund af områdernes faktiske interferens, trods al forskellighed.

Det er Jesper Hoffmeyers fortjeneste at kaste sig ud i oversættelsesarbejdet, når det drejer sig om forståelsen af informatikken (: datateknologi og bioteknik), og det er ambitionen at skitsere de menneskelige og sociale perspektiver, der kan ligge i disse teknologier. Så vidt, så godt.

Problemet ved Hoffmeyers projekt, hvis intention som sagt er prisværdig, er nu, at oversættelsesproblematikken i forehavendet er ganske fraværende som problematik. Det betyder et sandt virvar og en total mangel på selektion i eller overblik over det vidensmateriale fra humanog socialvidenskaberne, som Hoffmeyer inddrager. Det får især konsekvenser for de interventionsambitioner, Hoffmeyer har i forhold til antagelser indenfor human- og socialvidenskaber.

Den anden side af problemet er, at Hoffmeyer ikke har frigjort sig fra sine teknologiers auratiske magt. Deres tekniske spil kan sende hans tanke på lange udflugter ind i human- og socialvidenskabernes område. Og disse udflugters rute bliver vilkårlig, fordi de er styret af fascinationen over det tekniske spils udstråling.

\section{Konsekvensen}

At de nye teknologiers udstråling spiller en betydelig rolle i Hoffmeyers samfundsteoretiske konsekvensdragninger afsløres talrige steder $\mathrm{i} \gg$ Samfundets naturhistorie «, men gøres ikke selv til genstand for reflektion.

Det er en selvfølgelighed for Hoffmeyer, at de tekniske finesser, som de »snilde « teknologier inkarnerer, har meget vidtrækkende samfundsmæssige konsekvenser. »Udviklingen inden for elektroteknikken er gået vanvittig hurtigt, stærkt stimuleret af dens betydning for den militære anvendelse i rumfart og af satellitkonkurrencen. Hvis bilindustrien havde udviklet sig ligeså hurtigt, i de sidste 30 år, ville en Rolls Royce koste 2,50 dollars og køre 12 millioner kilometer på en liter benzin. Men den tekniske innovationsbølge på dette niveau er ikke slut endnu. Mikroerne vil blive endnu mindre, endnu billigere og endnu effektivere i de kommende år. Og et væld af nye anvendelser og nye principper vil dukke op. 
De samfundsmæssige konsekvenser af denne tekniske revolution har allerede meldt sig - men endnu er der efter al sandsynlighed kun tale om krusninger « (op.cit, s. 234).

Heri ligger, at den samfundsmæssige udvikling - på næsten deduktiv manér - kan afledes af logikken i de »snilde« teknologier. I Tor Nørretranders' artikler, f.eks. i artiklen »Skal det snilde nu være ilde«? i Naturkampen nr. 25, bliver konsekvensen af de nye teknologier et nyt og anderledes samfund, som han - formodentlig for at skjule det yderst traditionelle indhold bag betegnelsen - kalder for »poststokastisk kapitalisme«.

Den "post-stokastiske« kapitalisme, som Nørretranders deduktivt afleder af de nye teknologier, vil afskaffe konkurrencekapitalismens tilfældige og anarkiske træk og i stedet nødvendiggøre en centraliseret styring i totalkapitalens regi.

»Stokastisk « er hér det mystificerende fremmedord, som skal få læseren til at overse, at den anvendte argumentationsfigur har sit forlæg i ortodokst marxistiske, leninistiske og - ikke mindst - stalinistiske forestillinger om, at $\varnothing$ get teknologisering eo ipso fører til øget statsligg ørelse og dermed større kontrol med produktionsprocesserne.

En konsekvens af den $\emptyset$ gede »post-stokastiske« - kontrol med tingene, som de »snilde « teknologier nødvendigg ør, er iflg. Nørretranders, at hele det velkendte og frygtede $\varnothing$ kologiske problemkompleks - alle bivirkningerne af den kapitalisti- ske form for produktivkraftsudvikling - vil blive løst af de »snilde teknologier.

Den polemiske frontlinje i Nørretranders' arbejder går ikke primært imod de kapitalistiske former for udvikling af de nye teknologier. Frontlinjen går imod venstrefløjen, som p.g.a. dens manglende indsigt i de nye teknologier, holder fast ved traditionelle skemaer til forståelse af kapitalistisk produktivkraftsudvikling.

Nørretranders er så harmdirrende i sin polemik mod venstrefløjen, at han synes at glemme, hvem der faktisk administrerer udviklingen af de nye teknologier, og i hvilke samfundsmæssige former denne udvikling stadig foregår.

Denne uforsonlige kritik af påstået traditionalisme blandt venstreorienterede kan næppe begrundes rationelt. Dette gælder så meget mere, som Hoffmeyers og Nørretranders' samfundsteoretiske konstruktioner omkring perspektiverne i de »snilde teknologier hviler helt og aldeles på en ubearbejdet traditionalisme fra den ortodokst marxistiske tradition; dvs. dén tradition, som historisk går fra den sene Engels til Stalin.

Traditionalismen, som fanger Hoffmeyer og Nørretranders, kan teorihistorisk spores tilbage til den midterste del af Marx' og Engels' forfatterskab, men den har sine rødder helt tilbage $\mathrm{i}$ den borgerlige oplysningstænkning. Jeg tænker på den rigide skematisme omkring forholdet mellem produktivkræfter og produktionsforhold. 
Når denne skematisme kan fange Hoffmeyer og Nørretranders, uden at de lægger mærke til det, skyldes det uden tvivl, at de er berusede af deres teknologiers udstråling.

Hos Hoffmeyer kommer dette frem ved, at der ikke foretages nogen formidlet bearbejdning $\mathrm{i}$ feltet mellem det samfundsteoretiske/samfundskritiske kapitel om »Historiens drivkraft « og så den konkluderende tematisering af de »snilde « teknologier. Som venstreorienteret intellektuel har Hoffmeyer annammet elementer fra det nye venstres kritik af de bastante udgaver af den historiske materialisme, og han fremstiller - sympatisk - disse elementer i det nævnte kapitel.

Da bogen imidlertid når frem til de nye teknologier, er alt dog glemt. Blændet af det uendeligt store $\mathrm{i}$ det uendeligt små, for at anvende Brandes' også i denne sammenhæng træffende betegnelse fra »Hovedstrømninger..«, i de nye teknologier, går Hoffmeyer lige lukt i de fælder, man ellers troede af- sløret. Den i og for sig forståelige fascination over de nye teknologiers formåen betyder, at denne formåen ikke længere kan placeres kritisk indenfor en social- og humanvidenskabelig horisont. Og adskilligt tyder også på, at fascinationen får som konsekvens, at der ikke kan skelnes rationelt imellem, hvad de nye teknologier kan - og hvad de ikke kan.

Fascinationen kræver universalisering, hvad angår konsekvensdragninger; videnskabsteoretisk udtrykt: den kræver begrebsholisme. Det skyldes, at fascinationen qua førrationel ikke er i stand til at differentiere. Det er i denne situation, at skematismen produktivkræfter contra produktionsforhold byder sig til, fordi den netop er tænkt så universel og holistisk, som fascinationen har brug for. ${ }^{1}$

Skematismen opererer med, at produktivkræfternes inderste sandhed rækker ud over de produktionsforhold, der har skabt dem. Den opererer endvidere i sin klassiske form såvel som i Hoffmeyer/Nørretranders' ud-

1. Skematismen - produktivkræfter contra produktionsforhold - er ikke den eneste holistiske begrebsmulighed, der findes på teoriernes marked, hvis man vil drage universelle konsekvenser af informatikken. Når Hoffmeyer og Nørretranders vælger denne mulighed, skyldes det naturligvis, at de forstår sig som marxister.

I sin bog om det postmoderne samfund (»La condition postmoderne «), da. udg. Sjakalen, Århus 1982, anvender Jean-Francois Lyotard en anden mulighed, nemlig den franske epistemologis opgør med dualitets- eller binaritetstænkningen. Som bl.a. Foucaults analyse af seksualiteten viser, er et sådant opgør ofte forskningsfrugtbart. Dette rokker dog ikke ved, at pointerne i dette opgør med binariteten i dag anvendes holistisk. Når binaritetskritik kan mobiliseres i litteraturkritik (f.eks. i Deleuze/Guattaris bog om »Kafka. For en mindre litteratur«, Sjakalen, Århus, 1982), i seksualitetshistorie og altså i en analyse af de samfundsmæssige konsekvenser af informationsteknologien, som hos Lyotard, ja, så er begrebskritikken blevet holistisk, hvilket vil sige: differentieringsløs.

Det skal tilføjes, at Lyotards arbejde kommer ind på aspekter ved de senkapitalistiske og evt. »post-modernistiske « samfund, som i allerhøjeste grad er social- og humanvidenskabeligt aktuelle. Det skyldes ikke mindst, at den kritiske social- og humanvidenskabelighed er indarbejdet langt mere organisk i Lyotards problematikker, end tilfældet er i Hoffmeyers og Nørretranders' tilfælde. 
gave med, at denne sandhed pr. teknologisk nødvendighed vil sprænge de herskende produktionsforhold og bane vejen for et nyt samfund. Hos Marx (i den midterste del af forfatterskabet), Engels, Lenin og Stalin var det kommunismen, som med nødvendighed ville vokse frem af de moderne produktivkræfters udvikling. Hos Nørretranders og Hoffmeyer er det produktivkræfterne i de nye teknologier, som pr. nødvendighed vil skabe nye produktionsforhold; vil skabe et nyt samfund.

I dette nye samfund vil de $\varnothing$ kologiske problemer, som ellers har fyldt godt op i naturkampsdiskussionen og vel også er drivkraften, når hundredtusinder i BRD demonstrerer mod atomkraftværker, blive løst af den »post-stokastiske « kapitalisme. Hoffmeyer og Nørretranders vil slå oplysningens kolde vand i blodet på de »grønne « brushoveder. Den »grønne « bølge angriber problemet forkert, eftersom bivirkningskomplekset er bundet til energikulturen og vil blive løst af de »snilde « teknologiers økologiske produktivkræfter. Sådan lyder beskeden til den »grønne « venstrefl $\varnothing j$ fra de lærde naturvidenskabsfolk.

Tilbage står problemet med kontrollen af og magten over de nye produktivkræfter. Det er - så meget medgiver Hoffmeyer og Nørretranders - et problem, at de »snilde « teknologiers snildhed patenteres af de herskende. Snildheden anvendes til kontrol og undertrykkelse, men en sådan anvendelse er i virkeligheden imod snildhedens væsen.
Derfor $b ø r$ den forvildede venstrefløj - belært om snildhedens sande væsen - afføre sig sin »grønne« jakke og intervenere konstruktivt for at udfolde de nye produktivkræfters væsen. Venstrefløjen bør udvikle alternative anvendelser af de nye produktivkræfter, sådan at disses iboende tendens imod at skabe nye og herredømmefri produktionsforhold ikke hæmmes.

Denne strategi kan bifaldes. Venstrefløjen bør intervenere i informatikkens udviklingsretning, og den $b ø r$ afvikle de former for informatik, hvis materielle form afspejler funktionen: kontrol og undertrykkelse. Denne teknologikritiske differentieringsstrategi overfor de kapitalistisk udviklede produktivkræfter har gyldighed fra ludditterne frem til i dag. En sand teknologikritik balancerer på en akse midt imellem fremskridtsoptimisme og maskinstormeri, og den kan ikke andet, så længe teknologiudvikling foregår i kapitalistiske former.

Der er imidlertid ingen fornuftig grund til, at præcist den teknologikritiske intervention skulle få særligt revolutionerende effekter på produktionsforholdene. Nok er teknologien vigtig for samfundsudviklingen, men bl.a. af samme grund er det også vanskeligt for en venstrefløj at nå ind til dens hjerte. Man må i vidt omfang tage til takke med at fordele smulerne fra de mægtiges bord. M.a.o. er de mulige teknologiformer i høj grad præformeret materielt af deres kapitalistiske funktioner. Og det er kun en metafysisk og holistisk skematisme á 
la den ortodokse historiske materialisme, som kan regne med, at der netop skulle ligge en kommunistisk hund begravet hér.

Tilbage står, at der politisk, institutionelt m.v. bør interveneres omfunktionerende, nedbrydende såvel som konstruktivt i dette felt også. Men en sådan intervention figurerer på samme plan som interventioner i andre områder, og ingen af disse interventioner formår - hver for sig - at rokke ved produktionsforholdene.

Det er uheldigt, at Hoffmeyer og Nørretranders gør netop interventionen i forhold til de nye teknologier til den altafgørende i forbindelse med en venstrefløjs samfundskritik. Og det bliver ikke mindre uheldigt af, at de ledsager dette synspunkt med en nedladende kritik af temmelig mange andre samfundskritiske interventionsformer.

Det følger dog af den holistiske konstruktion, ud fra hvilken Hoffmeyer og Nørretranders begriber de »snilde « teknologier, at disses sandhed - »snildhed « - ikke i det lange løb kan undgå at komme for en dag, og da vil det nye samfund - den kommunistiske hund - rejse sig og sprænge de snærende bånd.

»Snildheden « vil komme på sit sande begreb og skabe et helt nyt samfund på trods af den bornerte venstrefløjs manglende forstand på de nye teknologier. Det véd især Hoffmeyer ud fra sin tyrkertro på produktivkraftsbegrebets revolutionerende potens. De økologiske produktivkræfter vil placere deres tidsindstillede bombe under den herskende, restriktive anvendelse af de nye tekno- logier, og frihedens rige vil opstå - åh, hvilket paradoks for tanken! - med nødvendighed.

Lad os, inden vi igen søger jordforbindelse, påhøre profetien in extenso, som den formuleres hos Hoffmeyer (op. cit., s. 279-280):

»Der er to afgørende grunde til, at jeg ikke tror, dette beherskelsesapparat vil kunne overleve i længden, og at det før eller senere vil blive afviklet - omend dette vil ske på en anden måde, end socialister normalt forestiller sig, og af en anden kraft end arbejderklassens.

Den ene grund udspringer af menneske-natur relationen: systemet kan ikke indfri de produktive løfter, informationsteknikkerne stiller i udsigt, det kan med andre ord ikke forvalte nødens afskaffelse, skønt denne nu er mulig.

Den anden grund har sin rod i menneske-menneske relationen: Systemet har været nødt til - for sin overlevelse at tillade den personlige tanke (som er Hoffmeyers afløser for »arbejderklassens kraft « - Hjt) at spire i sine mennesker.

Den første grund er ud fra det historiske eksempelmateriale ikke tilstrækkelig til at afstedkomme en ny produktionsmåde. Vi kan fx. sammenligne med det orientalske despoti i Kina, som gennem 500 år formåede at forhindre en revolutionær produktivkraft-udvikling baseret på de ikke-biologiske energikilder, selv om det havde overskredet tærskelen i form af vandkraften. På samme måde kan man i princippet (men hel- 
ler ikke mere, p.gr.a. »den personlige tanke« - Hjt) forestille sig, at den post-stokastiske kapitalisme vil kunne dæmme op for den decentralisering af informations- og stofstrømmene, som i virkeligheden er vejen til nødens afskaffelse.

Men der er intet, der tyder på, at det kapitalistiske beherskelsesapparat besidder en stabilitet, der i praksis vil tillade det at bestå, selvom befolkningerne mere og mere vender det ryggen. Det er grundlæggende afhængig af en fri bevægelighed, både rent fysisk og tankemæssigt, som i realiteten udelukker, at det kan fungere alene i kraft af politi, militær, edb-registre og psykofarmaka. For en tid kan noget sådant selvfølgelig lade sig gøre - en ny form for fascisme er foruden en tredie verdenskrig en af de mest sandsynlige korttids udsigter.

Hvis vi undgår den tredie verdenskrig, så er det min overbevisning, at selv et fascistisk styre ikke i længden vil kunne fungere. Det skyldes ikke, at mennesker er bedre nu, end de har været hele tiden. Det skyldes, at de ikke længere forstår sig selv som underordnede medlemmer af denne eller hin klasse. Det skyldes, at den frie tankes niche har beskyttet etableringen af de nye produktivkræfters projekt $\mathrm{i}$ vores hoveder: PERSONLIGGØRELSEN. Fra fabrikker og massepartier til uniformer og racer er fascismens kultur fremmed for den bevidsthed, der nu - med en ubønhørlighed, som kun kan have rod i de materielle betingelser - er på vej. Den frie tanke er farlig at have flagrende rundt i et samfund med $n \varnothing \mathrm{d}$ - endnu farligere bliver den, hvis nøden er unødvendig, hvis livet som PERSON vitterlig kunne realiseres $\ll$.

\section{Kritikken}

Jeg har ovenfor søgt at argumentere for, at Jesper Hoffmeyers brede civilisationskritiske konsekvensdragninger af de »snilde « teknologier ikke er human- eller socialvidenskabeligt plausible. Først og fremmest fordi de hviler på en paradigmatisk skematisme, som ikke længere kan have gyldighed for human- og socialvidenskaberne.

Langt flere dimensioner må inddrages, hvis samfundenes aktuelle og fremtidige konturer skal kunne anes. Nogle af disse dimensioner er antydet i det foregående. Endelig er det nødvendigt at være helt på højde med human- og socialvidenskabernes aktuelt kritiske niveau, og det er Hoffmeyer/ Nørretranders så langt fra. ${ }^{2}$

Tilbage bliver et vidtrækkende spørgsmål, om de moderne samfund de facto er ved at bevæge sig hen imod et socialt stadium, som i første omgang - og i mangel af bedre betegnelse - kunne kaldes for »det postmoderne samfund $\aleph^{3}$. Besvarelsen af dette

2. Det er til gengæld Jean-Francois Lyotard i det allerede nævnte værk, Viden og det postmoderne samfund. Det stærke er hér netop problembevidstheden, og kun sekundært er bogen en bog om »informationssamfundet«. Informatikken er for Lyotard eksemplifikation af postmodernitetens eksistens- og forståelsesbetingelser, og der er ingen hypoteser om, at det skulle være informatikken, som skabte disse betingelser. 
socialvidenskabelige spørgsmål må ske ud fra en differentieret indoptagelse af strukturer i den nuværende kapitalistiske modernitetsform. Og den må også have kendskab til nihilismens epokale problematik: der findes ingen ekstrahistoriske forsynsprincipper, som de historiske erfaringer og den historiske erkendelse kan lægges til rette efter.

Jeg vil imidlertid mene, at en betragtning af den nuværende kapitalisme på internationalt plan placerer hypoteser om fremtidens »informationssamfund « indenfor legitimeringens diskurs, for at tale med Lyotard. Intet andet end ubevidste ideologiske skematismer kan gøre sådanne hypoteser gangbare i hovederne på folk. De »snilde teknologier « tilhører human- og socialvidenskabeligt en forgangen epokes skematismer.

Den globale arbejdsdeling i verden peger næppe på et »informationssamfund « med de frelsende egenskaber, Hoffmeyer og Nørretranders tillægger et sådant. Dét forhold, at informationsteknologiens indførelse - f.eks. - i England skaber en $\varnothing$ get arbejdsløshed hér, er faktisk sociologisk sammenhængende med, at de tunge industrianlæg henlægges til den tredje verden, hvor de skaber $\varnothing$ get beskæftigelse - og profit, naturligvis. Ikke sjældent er sammenhængen fysisk anskuelig: de omtalte tunge industrianlæg flyttes faktisk til U-lande, når Ilandenes teknologier moderniseres.

Det er et nærliggende politøkonomisk spørgsmål i relation til denne sammenhæng, om denne sociale reorganisering af den kapitalistiske arbejdsdeling i global målestok ikke - når alt skal gøres op - fører til en større merværdiskabelse end da de nu arbejdsløse englændere stod i fabrikshallerne i stedet for de nyankomne i den 3. verden, som endnu levede i deres landsbyer eller i slumkvartererne i de stadigt voksende metropoler i den tredje verden for 15 år siden.

Herude ventes der med længsel på dén energikultur (med Hoffmeyers betegnelse fra »Samfundets naturhistorie «), som de avancerede industrinationer i dag er ved at lægge bag sig. Den tunge industri er også nødvendig hér, for at regionernes infrastrukturer kan udvikles. Dermed er der - naturligvis - intet sagt om, at disse regioners modernisering er bundet til kapitalismens sociale udviklingsform, tværtimod.

Der synes ikke at være grund til at antage, at kapitalismen ikke også fremover skulle indebære en ulige udviklingsog moderniseringsproces - under det overordnede og strukturerende værdiøgningsimperativ. »Informationssamfundet«, eller med den civilisationsmæssigt bredere betegnelse: postmoderniteten, er allerhøjest et civilisationsstadium, der vedrører de gamle industrinationer.

Der vil nok, med tiden, blive indarbejdet informationsteknologi i den tredje og fjerde verdens infrastrukturopbyggende industrier, men dette kan aldrig give anledning til en postmoderne civilisation. De informations-

3. Betegnelsen er ved at blive almindelig, men siger egentlig ikke i sig selv så meget - især ikke når dens forhold til moderniteten ikke afklares præcist. 
teknologiske komponenter vil drukne i regionernes elementære samfundsmæssige projekt: overvindelsen af hunger og tilfredsstillelsen af elementære behov.

I den forbindelse vil disse regioners hovedproblem ikke være spændingsforholdet mellem modernitet og postmodernitet, men afvikling af moderniseringens kapitalistiske form. Noget tyder på, at modernisering på ikke-occidentale betingelser sine steder overhovedet ikke er mulig, hvis den kapitalistiske form for modernisering ikke afskaffes. Befolkningerne synes ikke villige til at aflægge sig de traditionelle mytiske og religiøse verdensfortolkninger (i Indien og store dele af Afrika), hvis ikke de kan opnå profane gevinster ved at engagere sig i moderniseringsprocessen. Og det kan de jo faktisk ikke, når denne proces foregår i kapitalistisk regi. M.a.o.: mange steder kan modernisering ikke tænkes uden at være forbundet med social revolution, forstået som et opgør med moderniseringens kapitalistiske form.

Alt dette er civilisationsmæssige problemstillinger omkring modernisering, som overhovedet ikke kan fange blikket, hvis dette alene opholder sig ved moderniseringsprocessers tekniske komponenter. Og det er også eksempler på, at teknologiseringens og moderniseringens former langt fra er uvedkommende - også når det f.eks. drejer sig om at vurdere, om en modernisering overhovedet er mulig.

Også for de gamle industrinationers vedkommende vil jeg dog mene, at der er kraftige sociale indikationer for, at de nye teknologier - hvor revolutionerende de end er teknisk - næppe AF SIG SELV kan få revolutionerende social og human betydning.

Det hænger sammen med to ting. For det første er der et principielt brud imellem teknologisk innovation og social fornyelse. Dette er en lov, som gælder for "primitive « som for moderne samfund. I moderne samfund kommer der yderligere dette moment til, at der indsniger sig et kontingensrum imellem teknologisk innovation og social fornyelse, som gør det dybt problematisk at slutte fra det ene til det andet.

De moderne samfunds kontingens gør det muligt at foregribe en virkelig social og menneskelig emancipation. Emancipationen kan tænkes ved sig selv, hvilket betyder at den ikke - hverken logisk eller reelt - kan deduceres ud fra andet end sig selv. Kant pegede i »Kritik der reinen Vernunft « på, at der består en irreduktibel relation imellem naturkausalitet og frihedskausalitet, og denne skelnen har - efter min opfattelse - bevaret sin principielle sandhed. Iøvrigt findes den reproduceret i Marx' distinktion mellem nødvendighedens rige og frihedens rige.

Til denne principielle begrundelse for umuligheden af at aflede social fornyelse af teknologisk innovation vil jeg godt til sidst føje en mere fornemmelsesmæssig begrundelse.

Det forekommer mig overilet at mene, at den nuværende industrikapitalismes krise indvarsler et nyt civilisationstrin, fordi det vil være umuligt at 
genskabe en konkurrencekapitalisme, hvis vi overlever den nuværende krise.

Der er så mange »klassiske « træk ved den nuværende krises sociale karakter, som minder om, at kriseprocessen også er en renselsesproces. Undervejs skabes den sociale elendighed, den industrielle reservearmé, nedgangen i reallønnen, udrensningen af ikke-rentable kapitaler og forretningsdrivende m.v. Alle disse ting, som i dag foregår for øjnene af os, betyder for mig at se, at man skal være varsom med at drage alt for mange upræcise antagelser om noget ganske andet på den anden side af krisen.

Dette ganske andet, som skulle komme af sig selv, kan udpensles positivt eller negativt. Det kan blive en apokalypse eller et paradis; det kan være $\varnothing$ kofascismens rædsler, eller det kan være arbejdsfrihedens forjættelse. Der er nok af muligheder, når man skal gætte ud fra en mangesidet situation.

Jeg tror ikke meget på gæt. Men jeg er sikker på, at frihed nås ikke via nødvendighed. Frihedens modus er en anden end nødvendighedens. 


\section{Opgør med den autoritære socialisme}

\section{Solidaritets planer og forslag til samfundsmæssige og økonomiske reformer}

\section{Dokumenter fra Polen 1981}

Dokumenterne i denne bog stammer fra det såkaldte »Net « af repræsentanterforenrækkest $\varnothing$ rre virksomhederiPolen.Dette»Net « udgjorde en central initiativgruppe for oprettelsen og udviklingen af arbejderråd til den direkte overtagelse af virksomhederne i arbejdernes egne hænder. Med deres forslag om udviklingen af »samfundsmæssige virksomheder« ledet af arbejdernes »selvstyre« udgjorde de en vigtig strømning inden for Solidarność. Med parolen om virkelig samfundsmæssiggørelse til forskel fra statsliggørelse udtrykker »Nettet«s standpunkt en klar socialistisk tendens i det polske opgør.

Dokumenterne viser, at der i Polen var(er) en levende socialistisk opposition, som gjorde sig konkrete forestillinger om en helt anden slags socialisme. Generalernes totalitære udgave af statssocialismen kan ikke undertrykke de erfaringer og den indsigt, som er gjort. Uanset om man er enig eller ej med »Nettet «s diskussionsoplæg, er dokumenterne vigtige og presserende indlæg i diskussionen om vejen til socialisme.

Kurasje/politisk revy 


\section{Indhold i de seneste numre af Kurasje:}

Nr. 31, november 1982

F. Engels' »damp-marxisme«

Marx, Engels og dialektikken

Taylorisme og den »reelle subsumtion«

Maskinstorm

Ledelsesretten

Teknologikritik.

Nr. 30, april 1982

Fagbevagelsens konservatisme

Den kriseramte fagbevægelse

Korporatismediskussionens selvblokering

Om G. Markus

Fire former for kritisk teori

Kommentarer \& anmeldelser

Nr. 29, oktober 1981

Verdensmarkedstemaet

Udenrigshandel og værdilov

Værdilov og verdensmarked

Reformismetemaet

Socialdemokrati og samfundskrise

Tiden råber på ...? Kommentar til nogle aktuelle tendenser i marxismen

Nr. 27/28, april 1981

Radikalisering i krisen

Tilpasning eller opror

Hvem sagde krise

Staten og de materielle produktionsbetingelser

Om forholdet mellem det »logiske og det historiske«

\section{Abonner på Kurasje}

